\title{
VISION FILOSÓFICA DE LA SEXUALIDAD Y EL GÉNERO DESDE LA BIOPOLITICA EN MICHEL FOUCAULT
}

\author{
PROYECTO DE INVESTIGACION MAESTRIA EN FILOSOFÍA \\ LATINOAMERICANA
}

\author{
Presentado por: \\ DIANA ISABEL SUAREZ LUGO
}

Director:

ALVARO ACEVEDO GUTIERREZ

\author{
UNIVERSIDAD SANTO TOMAS \\ FACULTAD DE FILOSOFÍA Y LETRAS \\ MAESTRIA EN FILOSOFÍA LATINOAMERICANA \\ COLOMBIA \\ 2015
}




\section{Contenido}

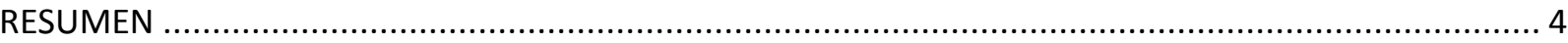

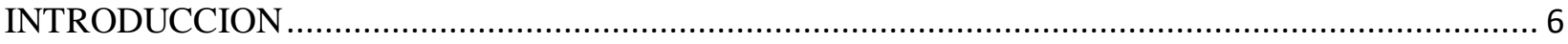

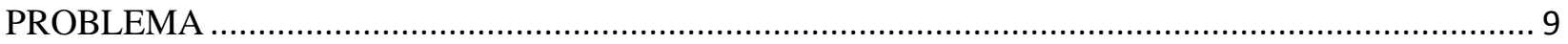

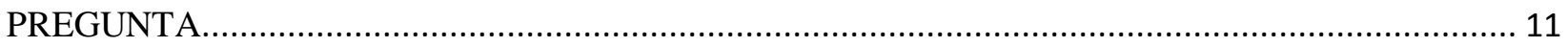

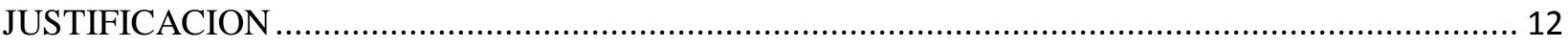

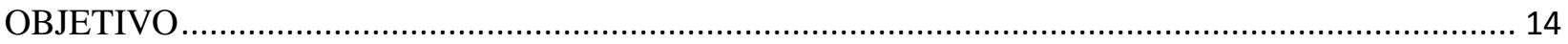

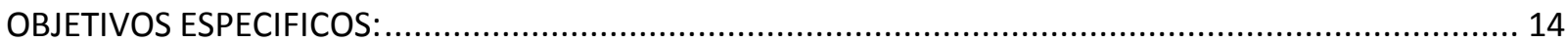

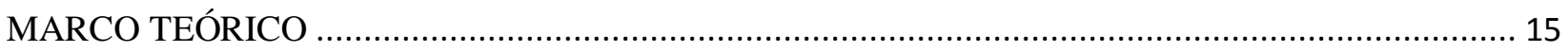

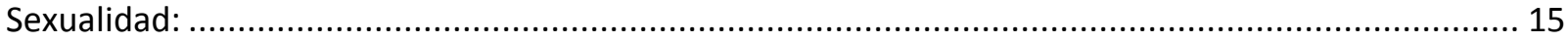

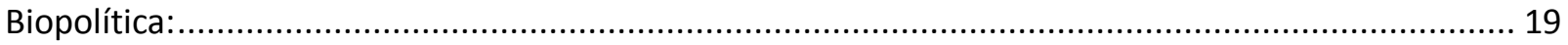

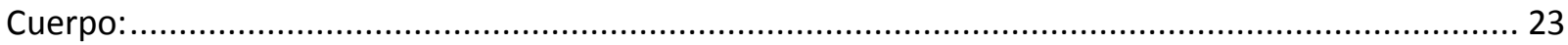

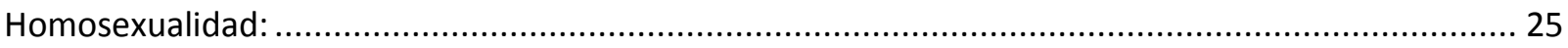

CAPITULO I

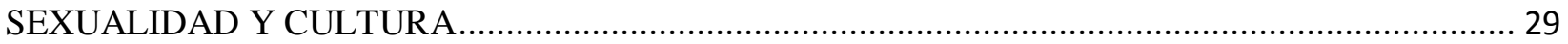

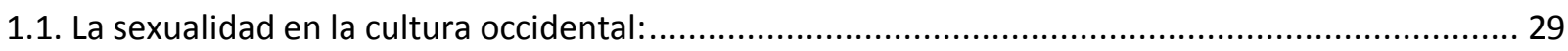

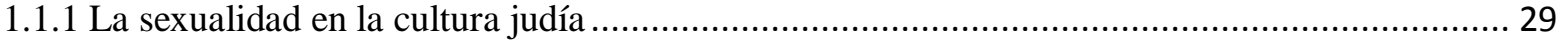

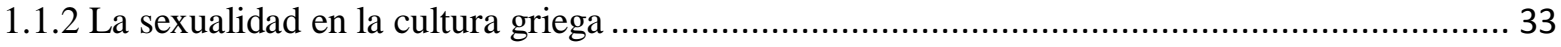

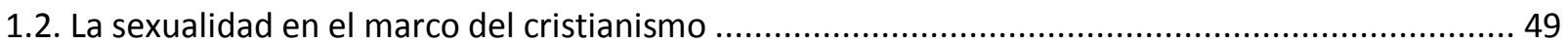

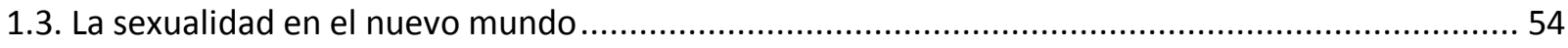

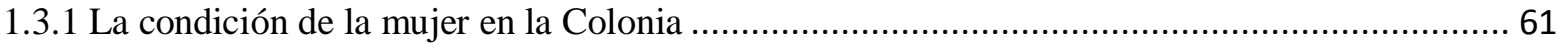

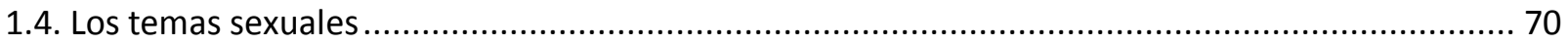

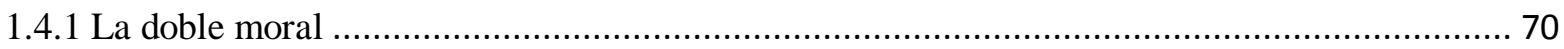

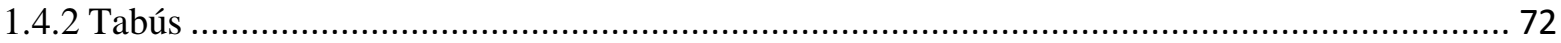

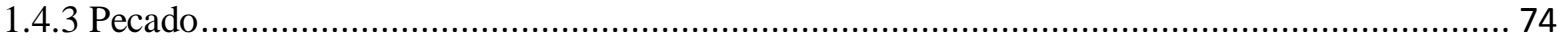

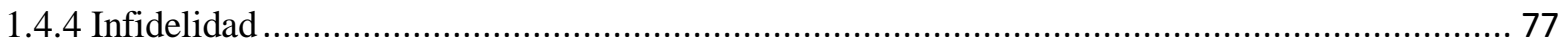

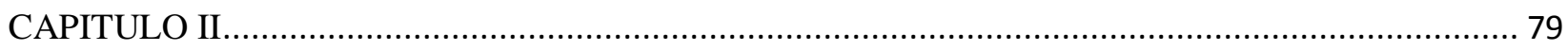

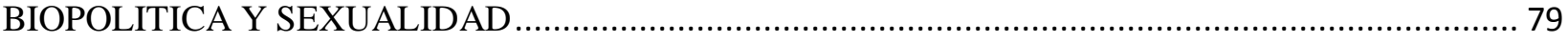

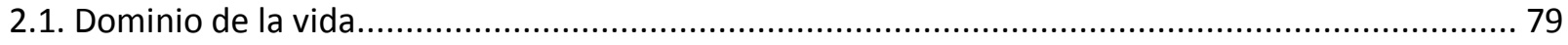

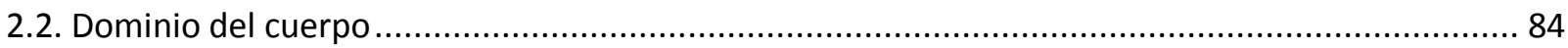

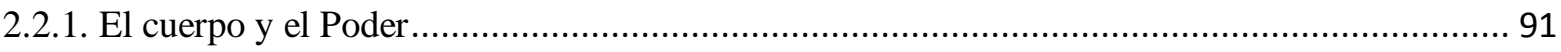

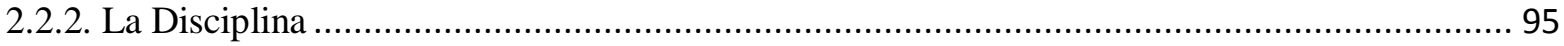




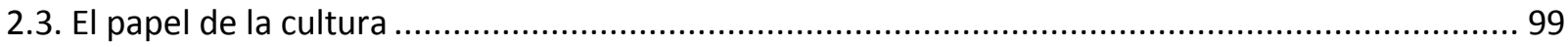

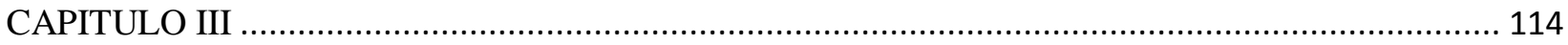

LA REPRESION DEL CUERPO Y LA SOCIEDAD CONTEMPORANEA ..................................... 114

3.1. Represión del cuerpo desde la visión de Michel Foucault .................................................. 114

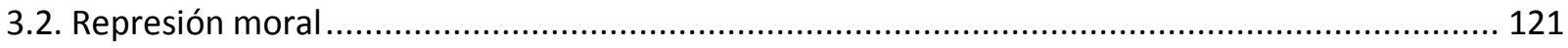

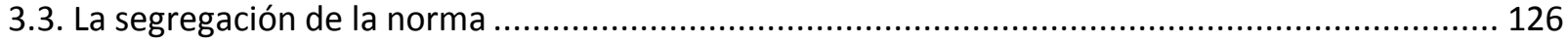

3.4. Las reivindicaciones legales de los segregados ............................................................... 130

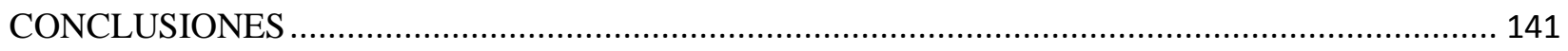

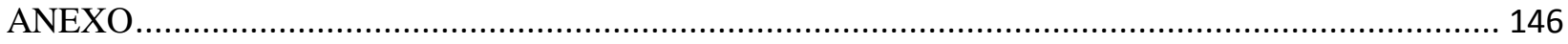

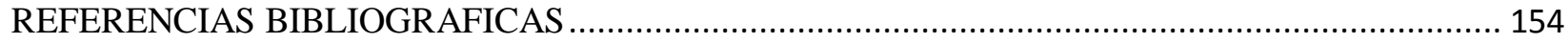




\section{RESUMEN}

El tema de la sexualidad a lo largo de la historia y las culturas se ha abordado de diversas maneras, sin embargo se encuentra como constante que ha sido vista desde las creencias y tradiciones religiosas, que a la vez han visto a la mujer como objeto de dominación masculina y le ha dado un papel secundario en la sociedad, de igual manera ocurre con las personas con opciones y vivencias sexuales distintas a las normativas desde la tradición y la religión. Es entonces que se hace necesaria una reflexión filosófica que aborde esta problemática y la interprete desde las políticas públicas y cómo ellas buscan dar respuesta a las necesidades en cuanto a los derechos de las minorías; es desde esta perspectiva que toma sentido la reflexión de Michel Foucault desde la biopolítica y las relaciones de poder en las sociedades modernas, para llegar a profundizar en la norma y su repercusión en la sexualidad y la vivencia de opciones sexuales diversas, así como su reconocimiento.

\footnotetext{
ABSTRACT

The topic of sexuality throughout history and cultures has been addressed in various ways, however is as constant that it has been seen from the religious beliefs and traditions, which in turn have seen the woman as an object of male domination and has given a secondary role in society, just as happens with people with different sexual orientations and experiences against from tradition and religion. It is then that a philosophical reflection that addresses this problem and interpret from public policies and how they seek to meet the needs for the rights of minorities is necessary; It is from this perspective that makes sense reflection of Michel Foucault from biopolitics and power relations in modern societies, to reach deeper into the standard and its impact on sexuality and experience of various sexual orientations, as well as its recognition.
}

\section{RESUMO}

A questão da sexualidade ao longo da história e das culturas tem sido abordada de várias maneiras, porém, é tão constante que tem sido vista a partir das crenças e tradições religiosas, que por sua vez, têm visto as mulheres como objeto de dominação masculina e lhe têm dado um papel secundário na sociedade, da mesma maneira, ocorre com as pessoas com opções e vivências sexuais diferentes às normativas da tradição e a religião. É então, que torna-se necessária uma reflexão filosófica que aborde esta problemática e a interprete a partir das políticas públicas 
enquanto elas procuram dar resposta às necessidades no que respeita aos direitos das minorias; é a partir dessa perspectiva que faz sentido a reflexão de Michel Foucault sobre a impolítica e as relações de poder nas sociedades modernas, para chegar a aprofundar a regra e a repercussão na sexualidade e a vivência de opções sexuais diversas, assim como o seu reconhecimento.

\section{PALABRAS CLAVE}

Sexualidad, Biopolítica, Cultura, Poder, Dominación, Creencias religiosas, Mujer, Diversidad, Multiculturalidad, Derechos, Educación, Tradición, Religión, Políticas Públicas. 


\section{INTRODUCCION}

La presente investigación tiene como título Visión Filosófica de la Sexualidad y el Género desde la Biopolítica en Michel Foucault. El tema principal es la sexualidad humana y cómo esta ha sido un tema tabú a lo largo de la historia, en la mayoría de las culturas y grupos sociales, de manera que la sexualidad a pesar de ser un aspecto fundamental en la vida del ser humano se toma como excusa para discriminar a quienes tienen opciones sexuales distintas a las establecidas.

La vivencia de la sexualidad se ha visto marcada por las creencias y tradiciones religiosas, en Latinoamérica se le debe sumar la dominación de la estructura masculina o machista y el papel secundario o relegado que se le ha dado y se le sigue dando a la mujer en la sociedad estructuralmente; lo que también ocurre con los derechos de minorías con vivencias sexuales u opciones sexuales diversas como el caso particular de las personas LGBTI que son víctimas de discriminación y de segregación.

De esta manera, esta investigación busca desde la filosofía contemporánea, profundizar en la biopolítica planteada por el filósofo francés Michel Foucault y su alcance, en la forma como se ha entendido la sexualidad humana como un medio de dominación y poder social.

Así, este trabajo busca realizar en el primer capítulo una revisión histórica de la visión de la sexualidad desde la cultura occidental pasando por tradiciones religiosas como son el judaísmo y el cristianismo y su herencia en cuanto a doctrinas religiosas. De igual manera, se hace una revisión de la vivencia de la sexualidad en la antigua Grecia, desde el análisis de la Historia de la sexualidad en el pensamiento de Michel Foucault. También se tiene en cuenta la vivencia de la sexualidad desde el enfoque de culturas prehispánicas y finalmente se hace una revisión de la forma como se implantó la herencia occidental en América por medio de la conquista y la evangelización.

En un segundo capítulo la investigación se centrará en profundizar desde la biopolítica los aspectos del dominio de la vida y del dominio del cuerpo, para comprender como la sexualidad es un instrumento de poder y de dominación. 
En el tercer capítulo se profundiza en la visión del cuerpo y la represión mental que sobre él se ejerce desde la medicina y el nacimiento de la clínica, ahondando en textos de Michel Foucault. Posteriormente en este mismo capítulo a modo de continuación con la represión de orden mental presente en la sociedad se determinan aspectos como la represión moral y la segregación desde la norma. Para finalizar el capítulo se tendrán en cuenta las reivindicaciones legales de los segregados y los avances en cuanto a la igualdad en derechos sexuales y en lo relacionado con el género, desde la implementación de políticas públicas y su respectiva aplicación.

La metodología aplicada en la investigación es la revisión y el análisis de textos sobre elementos de la sexualidad y la vivencia cotidiana de esta en distintos momentos y culturas, con esto se ha hecho un recorrido plural y en ocasiones contradictorio para llegar a encontrar las huellas y la influencia que han tenido aspectos como la educación, la tradición y la religión en la forma como los seres humanos conciben la vivencia de su propia sexualidad. Así entonces se han analizado distintos momentos buscando puntos comunes al profundizar en lo que la historia no evidencia y en aspectos de los cuales las culturas poco hablan como es la vivencia de la sexualidad, aspecto que se debe analizar solamente al buscar historias de lo que se considera privado, de manera que se van dando en el transcurso de la investigación rupturas y distintos puntos de vista, que nos llevan a considerar las preguntas de Michel Foucault en la introducción de la Arqueología del Saber (1979): ¿qué vínculo establecer entre acontecimientos dispares? ¿cómo establecer entre ellos un nexo necesario? (p.4), de manera que en la presente investigación se busca no solo establecer de forma general las razones por las cuales se instituyen ciertas conductas y formas de pensar de los grupos humanos, sino que ahonda en algunos de los aspectos utilizados por Michel Foucault como son el psicoanálisis, el discurso y la teoría social, como investigaciones que en palabras de Foucault (1979): "han descentrado al sujeto en relación con las leyes de su deseo, las formas de su lenguaje, las reglas de su acción, o los juegos de sus discursos míticos o fabulosos" (p.21), de manera que se busca no centrarse en grandes temas específicos, sino que se analizan distintos textos dispares y diversos entre sí, para llegar a establecer como punto común como el cuerpo y alma son concebidos como una prisión o un elemento de dominación tanto desde la religión como desde el capitalismo. 
En esta revisión de textos se sigue el camino de Michel Foucault en cuanto al discurso como elemento de análisis de formas del pensamiento, como lo entiende el autor en la Arqueología del Saber (1979): "El análisis del campo discursivo se orienta de manera muy distinta: se trata de captar el enunciado en la estrechez y la singularidad de su acontecer" (p.45), de manera que en la variedad de discursos se busca encontrar correlaciones a manera no de unidades o categorías generales, sino que se buscan puntos comunes que ayuden a ver el tema principal de esta investigación desde puntos de vista más singulares y particulares, explorando finalmente al propio sujeto. Para tal fin se tendrán en cuenta instancias como la medicina, la psiquiatría y la justicia vistas por Michel Foucault en: El Nacimiento de la Clínica (2004) y La Historia de la locura en la época clásica I y III (1998) y Vigilar y Castigar (2002).

Teniendo en cuenta que esta investigación ahonda en aspectos puramente teóricos pero que tienen profunda implicación en la vida diaria de las personas, al final se encuentra un anexo en el que se aplicó un instrumento tipo encuesta a estudiantes de grado $11^{\circ}$ de cuatro colegios distritales de igual número de localidades de la ciudad Bogotá, con el fin de comparar y convalidar los temas estudiados en la presente investigación y sentar las bases para demostrar que es necesaria la construcción de una propuesta pedagógica basada en la tolerancia y el respeto, que lleve a los individuos a ver al otro como complemento, y que desde el respeto a la sexualidad se pueda llegar a respetar todos los aspectos del ser humano. 


\section{PROBLEMA}

La sexualidad es un aspecto fundamental del ser humano a lo largo de la vida, abarca el sexo, las identidades y los roles de género, la orientación sexual, el erotismo, el placer, el vínculo afectivo y la reproducción. Es influenciada por la interacción de factores biológicos, psicológicos, sociales, económicos, políticos, culturales, éticos, legales, históricos, religiosos y espirituales.

Las influencias sociales en torno a la sexualidad nos afectan a todas las personas, una de estas influencias es el género; es decir, las expectativas acerca de que las mujeres y los hombres, las niñas y los niños han de comportarse de maneras diferentes unas y unos de otros y otras.

A lo largo de la historia las sociedades han aceptado o rechazado esta interacción entre sexualidad y los roles culturales propios del género, dando como resultado una visión única y sesgada sobre el género y la sexualidad, llevando a rechazar las manifestaciones distintas a la aceptada.

A finales del siglo XX surgen como procesos de construcción social otras orientaciones sexuales que recogen las categorías de homosexualidad (lesbiana, gay, bisexual, transgenerista), que cuestionan la posición tradicional de relación entre hombres y mujeres.

En la Grecia antigua la relación homosexualidad-heterosexualidad presenta una clara diferencia respecto de nuestra sociedad, pues en Grecia la homosexualidad era una práctica para nada desconocida y que se puede decir hacía parte de la educación de los jóvenes, pues las mujeres eran consideradas ciudadanas de segunda, no acostumbraban a salir de casa y su responsabilidad era mantener el orden del hogar, de donde se desprenden todos sus deberes entre ellos el más importante: el de madre de familia, lo cual la diferenciaba de un esclavo doméstico. Desde el día del nacimiento hasta el de su muerte, una mujer de la antigua Grecia vivía bajo el control de los hombres fueran estos su padre, sus hermanos, su marido e incluso sus hijos, quienes tomaban decisiones que alteraban su vida.

Para los investigadores Ghul E. \& Koner W (2002): "la mujer era de naturaleza inferior a la del hombre" (p.45) opinión griega que le dio un papel secundario con respecto a los derechos 
cívicos ya que no podían votar ni tener un empleo público, heredar o poseer propiedades y mucho menos compartir la vida intelectual de su marido. Sin embargo una mujer no carecía totalmente de poder, ya que dirigía la casa y controlaba el dinero de la familia, puesto que los hombres pasaron la mayoría de su tiempo lejos de sus casas, la vida del espacio privado griega, fue dominada por las mujeres.

De esta misma manera el arte en cualquiera de sus facetas siempre ha sido dominado por el género masculino, dejando a la mujer como arrinconada y solo desde la perspectiva masculina, y así la mujer aparece como una musa, como objeto o fuente de inspiración más no como agente creativo que sea capaz de expresarse por medio de una obra de arte.

En cuanto a la literatura la mujer siempre ha estado presente desde muchos siglos atrás, en teoría era libre, pero los hechos la mostraban como poco más que una esclava, pues le estaba vedado todo lo que no tuviese que ver con el hogar, la maternidad y las labores domésticas. No es de extrañar entonces que, si se toma en cuenta la historia de la literatura, la lista de escritores es larguísima y la de las escritoras es muy corta, aunque en los últimos tiempos esa lista de escritoras ha aumentado notoriamente.

Por lo tanto no es difícil ver que la mujer pertenece al único grupo humano que sin haber constituido jamás una minoría, se la ha discriminado mucho más sutilmente y ha sido vista y valorada desde el deseo masculino, considerando mal vista a la mujer que se muestre desde perspectivas diferentes.

Por otra parte históricamente la homosexualidad se ha entendido desde lo masculino, pero son muy pocas las referencias hacia la homosexualidad femenina y mucho menos a las identidades trans. Igualmente la homosexualidad y la religión están unidas en una relación con muchos altibajos, puesto que siempre se ha tachado a la atracción de un individuo hacia otro de su mismo sexo como algo antinatural, desagradable, ocasionando en la comunidad manifestaciones de rechazo que van desde rechazo verbal, campañas de satanización hacia la persona, aislamiento e incluso la expulsión del grupo; así, aunque las religiones tienen sus diferencias, todas se encaminan hacia un punto en particular frente a la homosexualidad: $\boldsymbol{e l}$ rechazo. 
Teniendo en cuenta que nuestra Latinoamérica es un continente predominantemente cristiano y con arraigadas costumbres religiosas, así como una moral cristiana bastante estricta, no es de extrañar que este rechazo del cristianismo a la homosexualidad se proyecte en la población hacía personas con una tendencia sexual diferente a la aceptada.

Es desde este contexto que se da dado una reciente preocupación de los teóricos de género el comenzar a desmantelar la dureza, tanto cultural, como conceptual, de las categorías con las que tradicionalmente se ha estudiado y analizado la sexualidad humana. Así, por ejemplo Foucault, considerado el inaugurador de una fructífera corriente de pensamiento al respecto, se pregunta en el primer volumen de Historia de la sexualidad: la voluntad de saber (2007) acerca del porqué de esa: “¿Censura respecto al sexo?”, a lo cual responde: “[...] más bien se ha construido un artefacto para producir discursos sobre el sexo, siempre más discursos, susceptibles

de funcionar y de surtir efecto en su economía misma". (p.16). Con esta respuesta logra poner en entredicho la existencia del sexo verdadero o de una verdad con respecto al sexo, pues deja al descubierto que la fluctuación de discursos de poder, condiciona la aparición de una economía de placeres, fuertemente machista y excluyente.

\section{PREGUNTA}

¿Cuáles son los principales aportes que hace Michel Foucault a una nueva comprensión de la sexualidad y género en el contexto de la biopolítica? 


\section{JUSTIFICACION}

La reflexión filosófica contemporánea, especialmente la reflexión e investigación de Michel Foucault en la historia para desmontar los aparatos ideológicos, que han servido para reprimir a través del sexo la conducta humana, logrando cuestionar la verdad sobre el sexo, han mostrado su precaria solidez y la necesidad de una constante renovación.

Es necesario por tanto, aterrizar la reflexión filosófica sobre un tema de estudio muy actual que a lo largo de la historia en Latinoamérica ha sido tabú y que dada su creciente importancia en la sociedad, me lleva a profundizar en los estudios de la sexualidad humana y el género realizados por Michel Foucault desde la biopolítica, y desde allí hacer la reflexión sobre por qué aún hoy se dan discriminaciones en personas pertenecientes a la comunidad LGBTI.

Para lo cual es importante profundizar en el concepto de minoría, entendido este como los grupos de personas que tienen unas características propias de orden étnico, económico, político, social y cultural, y que por estas mismas características son excluidos y no se consideran que formen parte de los círculos de poder que conducen los destinos de las sociedades.

Tradicionalmente los grupos de personas con opciones sexuales distintas a la normativa se han considerado como uno de estos grupos a los que se les niega la oportunidad de visibilizarse en los denominados círculos de poder y por lo tanto no encuentran representatividad, ni canales de expresión que posibiliten cambiar esta condición de "grupo marginal", de manera que se evidencia una exclusión social, económica, educativa, en salud y política de estas personas, haciendo difícil la creación de procesos de convivencia social democrática y del ejercicio de las libertades públicas y privadas, como el derecho a la salud, el derecho a la igualdad, el derecho a la vida, el derecho a la educación, el derecho a la autodeterminación, el derecho al trabajo, el derecho al libre desarrollo a la personalidad.

Los grupos marginados han sido caracterizados como tal, justamente por quienes sustentan el poder y definen el "deber ser" de los comportamientos sociales de este grupo de población colocándolos en una condición de marginales y clandestinos. El auto rechazo y la auto exclusión son las conductas naturales que impiden que estos grupos se movilicen y exijan ser 
visibilizados y se atiendan sus necesidades, de igual forma esta condición de clandestinidad impide su participación en los proyectos de construcción social ya que por su condición de grupo minoritario se les excluye a pesar de ser una inmensa mayoría.

Es evidente la carencia que tiene la salud pública frente a personas que viven con una enfermedad de transmisión sexual o el SIDA, más aún si no se cuentan con los recursos económicos para obtener servicios mínimos en condiciones de oportunidad y óptima calidad. Para el investigador Manuel Velandia (2007): "la inmensa minoría en salud al igual que las minorías sexuales, son considerados como ciudadanos de tercera, desheredados y excluidos" ${ }^{1}$, lo cual claramente atenta contra la dignidad y la igualdad de todos los habitantes de la nación colombiana, regidos por un Estado Social de Derecho que claramente no debería permitir que se den estas situaciones de evidente desigualdad y vulneración de los derechos humanos.

De esta manera el objetivo de esta investigación será profundizar en las corrientes existencialistas de la filosofía contemporánea, su visión frente a la sexualidad humana y de esta manera articular tales aportes teóricos e investigativos sobre la sexualidad al tratamiento que el ordenamiento jurídico colombiano da a las sexualidades no normativas, haciendo énfasis en la auténtica realidad a pesar de la legislación de inclusión, para llegar a indagar por las causas por las cuales la comunidad LGBTI aún es víctima de discriminaciones, violencia por prejuicio, violencia policial e invisibilización de parejas del mismo sexo.

\footnotetext{
${ }^{1}$ Velandia, M. (2007, julio). Manuel Antonio Velandia Mora, Autografía y Artículos. Recuperado de: http://manuelvelandiaautobiografiayarticulos.blogspot.com/Consultado: 25-05-12.
} 


\section{OBJETIVO}

Identificar e interpretar los aportes de Michel Foucault, para la comprensión de la sexualidad y el respeto por el otro, en el contexto de la filosofía contemporánea y su contribución en la construcción de políticas públicas de género e inclusión.

\section{OBJETIVOS ESPECIFICOS:}

- Hacer una reconstrucción de cómo se ha entendido la sexualidad en la cultura occidental teniendo en cuenta el papel de la mujer, y la homosexualidad, entendida como transgresión a la norma de poder y control social.

- Analizar los aportes de Michel Foucault sobre la sexualidad y su contribución para desmontar los aparatos ideológicos, que han servido para reprimir a través del sexo la conducta humana y construir nuevas categorías frente a la orientación sexual en el siglo XXI.

- Identificar la problemática real actual por el pleno reconocimiento y ejercicio de los derechos humanos de las personas LGBTI (Lesbianas, Gay, Bisexuales, Transgeneristas e Intersexuales) en Colombia. 


\section{MARCO TEÓRICO}

Se trabajan a lo largo de la presente investigación las categorías de sexualidad como elemento vital para el ser humano y mecanismo de represión y subyugación; la biopolítica teniendo en cuenta el problema de la vida y su visión desde el campo de pensamiento político, las relaciones de poder y el papel del Estado y allí mismo el poder como elemento de dominio, utilizado en las relaciones de todos los seres humanos y presente en todas sus relaciones; el cuerpo como elemento receptor de políticas de control policial, social, administrativo, sanitario, económico; homosexualidad como vivencia de la sexualidad, considerada como trasgresión de la norma y contraria a la conducta establecida por la tradición y la cultura.

\section{Sexualidad:}

Haciendo una revisión sobre la perspectiva que ha tenido la filosofía, de la sexualidad, es necesario hacer un rastreo hasta la filosofía moderna, donde se encuentra a Arthur Schopenhauer quien se puede decir es el primer filósofo que se atreve en su obra: el mundo como voluntad y representación, a desligar la voluntad de la razón, y así puede reivindicar para la voluntad una parte importante y fundamental en el desarrollo de la vida del ser humano, como lo expresa el mismo Schopenhauer (2005): "el impulso sexual se confirma como la más decidida y fuerte afirmación de la vida también el hecho de que tanto para el hombre natural como para el animal constituye el objetivo último, el fin supremo de su vida" (p.436), de tal manera que el impulso sexual, equiparado con la voluntad y desligada de la razón, se puede considerar que obra de manera totalmente libre, sin obstáculos racionales sino solamente guiada por la fuerza de la naturaleza, guiada por la voluntad de vivir. Esta voluntad se manifiesta básicamente de dos

formas: la primera de ellas es el deseo sexual como tal y la segunda es el apego a la vida que es la expresión de quien experimenta la voluntad de vivir.

Así, Schopenhauer desliga la voluntad de la razón, de manera que el intelecto deja de ser lo principal en la vida del hombre, pues lo principal es la voluntad y con esto necesariamente se da una inversión a la filosofía, dándole un énfasis más hacia la vida, es decir un énfasis más antropológico y por ende lleva a ver el ser humano como un ser sexual.

Continuando desde esta visión se encuentra Sigmund Freud quien identifica el "instinto sexual", o como lo reconoce Freud (1981): "La ciencia usa en este sentido la palabra lídido" 
(p.1172), como un instinto presente desde la cuna, y una constante búsqueda de placer, aunque en la infancia se niegue. Para Freud el fin de la sexualidad es el acto sexual y los eventos que conllevan a este, sin embargo este instinto sexual se manifiesta como la fuerza motivadora del ser humano, que a lo largo de la vida se disfraza, se sublima, se ignora, y en ocasiones puede ocasionar serios problemas neuróticos para el individuo, lo que expresa Freud (1981): "la tarea de dominar por medios distintos de la satisfacción un impulso tan poderoso como el instinto sexual es tan ardua que puede acaparar todas las energías del individuo” (p.1255).

Esta continua pulsión se origina por la lucha constante de Eros y Tánatos, que engendran en el hombre una continua lucha de pulsiones, donde Eros se puede identificar como el instinto de la vida, el deseo sexual en sentido amplio y Tánatos representa la muerte, complementario y contradictorio de Eros, supone las tendencias autodestructivas o destructivas sin más, esto genera un sistema en el cual las dos pulsiones van indisolublemente unidas y no puede una liberarse de la otra, lo que Freud (1981) expresa: "Las manifestaciones del Eros eran notables y bastante conspicuas; bien podía admitirse que el instinto de muerte actuase silenciosamente en lo íntimo del ser vivo, persiguiendo su desintegración” (p.3050). Este sistema es el psiquismo como expresión de la lucha de fuerzas en actuar constante e inconsciente, regido por la constante búsqueda del placer, en palabras de Freud (1981): "El término libido puede seguir aplicándose a las manifestaciones del Eros para discernirlas de la energía inherente al instinto de muerte" (p.3052).

La vida social, reprime el instinto sexual constantemente y así la sexualidad debe subordinarse al trabajo, a la reproducción monogámica y a las leyes del orden social ya que si los instintos se dejan abandonados a sí mismos, pueden destruir todo. De este modo no es posible según Freud una civilización no represiva, de manera que cuanta más civilización hay más represión.

Continuando con las tesis de Freud se encuentra Herbert Marcuse, que desde la escuela de Frankfurt toma las tesis de Freud al ver el fundamento de la civilización desde la represión de los instintos primarios del ser humano, de manera que la civilización se ha construido desde la supresión de la libertad humana y de los instintos, entre estos el placer que se ha cambiado por el 
trabajo, la sociedad, los compromisos y valores sociales, dando como resultado una constante de renuncias al erotismo y a los instintos. Sin embargo para Marcuse no todo el trabajo debe ser desagradable ni debe necesariamente implicar renuncia, es ejemplo de esto el trabajo creativo y el arte. Otro planteamiento de Marcuse es el desarrollo de la técnica para enajenar los instintos, este desarrollo de la técnica también conlleva la destrucción tanto de la vida como del entorno (planeta), y encasilla las acciones de los seres humanos de acuerdo a la división social del trabajo dando roles específicos. Sin embargo Marcuse da un paso más en este análisis de la relación sociedad y libido, e introduce nuevos aportes: 1. Represión sobrante como principio económico que hace referencia a la cantidad de energía libidinosa que se desvía de sus fines para luego ser necesaria en la construcción de la civilización, que domina al hombre, para Marcuse (1983): "la civilización empieza cuando el objetivo primario —osea, la satisfacción integral de las necesidades- es efectivamente abandonado" (p.27) de esto se encarga el Capital; 2. Principio de actuación es la forma histórica de dominación del placer y enmarcado desde el capitalismo, que ve el cuerpo como un instrumento meramente de trabajo.

En la filosofía contemporánea se encuentra Michel Foucault, quien enuncia en el volumen II de la Historia de la Sexualidad: El uso de los placeres (2007), que no intenta hacer lo que él llama una "genealogía de la sexualidad" (p.9), pero si hace una reconstrucción de conductas y comportamientos sexuales que poco a poco van configurando lo que se conoce como sexualidad, término que según Foucault aparece a principios del siglo XIX. Sin embargo la sexualidad se ha visto en relación con una cantidad de instituciones que la han condicionado, normalizado, estudiado, etc; y así mismo los comportamientos sexuales se ven configurados por instituciones como la iglesia, la familia, la fábrica, la escuela, la clínica.

Así para Foucault (2007): "se trataba... de ver cómo, en las sociedades occidentales modernas, se había ido conformando una "experiencia", por la que los individuos iban reconociéndose como sujetos de una "sexualidad"" (p.7), de manera que la forma como Foucault analiza la sexualidad es desde una cantidad de experiencias dentro de la cultura, teniendo en cuenta: "campos del saber, tipos de normatividad y formas de subjetividad" (p.8). Para hacer este análisis Foucault primero considera al hombre como: "sujeto de deseo" (p.9), distinto de lo que 
considera el cristianismo como la "carne" y concepto con el cual se ha conocido y designado la sexualidad en la cultura occidental desde la religión cristiana.

Sin embargo el interés principal de Foucault al analizar el concepto de sexualidad es examinar desde la historia la forma como los sujetos han reflexionado sobre sí mismos y sus comportamientos sexuales, entendiéndose como sujetos deseantes, que continuamente se encuentran en razón de este deseo inmerso en múltiples relaciones de poder, lo que llama Foucault (2007): “el ejercicio de los poderes” (p.9), de tal manera que la sexualidad se ve entendida desde la continua dominación que las diversas instituciones y relaciones humanas ejercen sobre el sujeto, como lo expresa Foucault (2007): “analizar, no los comportamientos ni las ideas, no las sociedades ni sus "ideologías", sino las problematizaciones a cuyo través el ser se da como poderse y deberse ser pensado y las prácticas a partir de las cuales se forman aquellas" (p.14)

Partiendo de esta continua dominación Foucault ve que la sexualidad se ha entendido como una especie de problematización a la que le atribuye cuatro conductas que desde la antigüedad han sido características de la sexualidad: "la expresión de un temor, un modelo de comportamiento, la imagen de una actitud descalificada, un ejemplo de abstinencia" (p.17), en cuanto al temor se encuentra que quien abuse o malgaste su energía sexual va a sufrir quebrantos de salud y se le va a notar en su semblante; el modelo de comportamiento hace referencia a la invitación a vivir la sexualidad de forma ordenada dentro del matrimonio y teniendo como finalidad la procreación; la imagen hace referencia al comportamiento o conductas de los homosexuales que se hacen notar inmediatamente y son las personas a quienes se les debe descalificar por su forma exagerada de comportarse; un modelo en cuanto la persona se comporta de forma virtuosa siendo capaz de vencer las tentaciones y así ser capaz de dar evidencia de su templanza. Estas cuatro conductas harán parte de la moral cristiana y serán el ideal de forma de comportamiento del cristiano y que finalmente se convertirán en el ideal de comportamiento de la sociedad occidental.

Es decir que la sexualidad ha sido entendida tanto en la antigüedad como en la modernidad y aún hoy desde la represión, que para Foucault se hace más evidente bajo el régimen victoriano y que coincide también con el desarrollo del capitalismo, lo que hace ver el 
autor en el volumen I de la Historia de la sexualidad: La voluntad del saber, bajo la figura de la sexualidad conyugal encaminada a la procreación como la única forma válida y establecida para vivir la sexualidad, según enuncia Foucault (2007): "Tanto el espacio social como en el corazón de cada hogar existe un único lugar de sexualidad reconocida, utilitaria y fecunda: la alcoba de los padres"(p.9), de manera que los demás sitios y formas de vivencia sexual son silenciados y se busca negarlos con el afán de hacerlos desaparecer.

No es casualidad que la única forma aceptada y establecida de sexualidad sea la encaminada a la reproducción en los siglos en los que el capitalismo se encuentra en auge y propone nuevos y eficaces modos de producción, de manera que la sexualidad también se debe encaminar hacia la producción y el rendimiento de fuerzas, para Foucault (2007): "si el sexo es reprimido con tanto rigor, se debe a que es incompatible con una dedicación al trabajo en general.’'(p.12), lo que hace que se necesiten una cantidad de normas y prohibiciones tanto al interior de la familia como en la sociedad para velar que la sexualidad solamente tenga como finalidad la reproducción

Desde allí es entonces que Foucault (2007) entiende la represión sexual desde: “el poder, saber y sexualidad" (p.11), de manera que se construyen discursos respecto a la sexualidad humana que solamente buscan reglamentar las conductas consideradas como anormales y la vivencia de la sexualidad, lo que Foucault (2007) llama: “técnicas polimorfas de poder” (p.19), que son la forma como el poder llega a controlar cada una de las conductas individuales, familiares y sociales del individuo. Así entonces toda palabra que se pueda decir con respecto al sexo está enmarcada dentro de lo que considera Foucault (2007): "la "puesta en discurso" del sexo" (p.19).

\section{Biopolítica:}

Uno de los intereses de estudio y análisis de Michel Foucault (2007), además de las relaciones de poder, es el análisis de lo que llama: El arte de gobernar (p.16), entendido como las muchas maneras que se pueden utilizar para guiar a los individuos y llevarlos a actuar de una manera u otra, tema estudiado por Foucault en los cursos ofrecidos en el College de France en 1978 y 1979, en donde comenzó a utilizar el término Biopolítica. 
Este gobernar se debe entender no solamente desde el guiar una comunidad, ciudad, o nación; también se entiende por gobernar el saber llevar los destinos de la familia, los hijos, la casa, un grupo de creyentes, etc, de manera que quien gobierne debe tener cierto poder para cambiar o intervenir en la vida de los gobernados con el fin de llegar a cierta finalidad, lo que Foucault (2007) expresará como: "reglamentar la vida de sus súbditos...tiene por correlato la ilimitación en el ejercicio del Estado de policía” (p.23), es decir la continua vigilancia, monitoreo y racionalización de todos los aspectos que tienen que ver con la vida del individuo, tal como son: la natalidad, las enfermedades, las prácticas sanitarias y de higiene, la longevidad, la mortalidad, como aspectos que pueden asegurar lo que llama Foucault (2007): "la prosperidad de una nación" (p.30), de manera que el problema de gobernar se relaciona directamente con la vida de los gobernados, pues son ellos quienes finalmente son la mano de obra y el insumo para que funcione y se mantenga prospera una economía, por tanto esta población debe estar siendo continuamente organizada, contada y medida de forma estadística para que el responsable del gobierno proponga nuevas estrategias en las cuales se tenga en cuenta y se mejore la vida del individuo, convirtiéndose este en un interés político primordial.

De esta manera el antiguo derecho soberano de vida y muerte se focaliza ahora en la vida o por lo menos en administrarla, lo que argumenta Foucault en la Voluntad de saber (2007): “el poder reside y ejerce en el nivel de la vida, de la especie, de la raza y de los fenómenos masivos de población" (p.166). Pero el interés fundamental para que se cambie la muerte por la vida o mejor por la preservación y protección de esta se puede decir que tiene un interés hacia el enriquecimiento del Estado, pues en la medida que la población tenga bienestar así mismo será más productiva.

Esto implica que todas estas medidas para procurar el bienestar de los individuos se apliquen al cuerpo, convirtiéndolo en el fundamento de todo lo relacionado con la enfermedad, la alimentación, la higiene, los cuidados, los medicamentos y demás aspectos que llevan a ver el cuerpo como lo denomina Foucault (2007): “cuerpo como máquina” (p.168), donde se configuran todos los sistemas de control descritos anteriormente y el "cuerpo-especie" (p.168) donde confluyen todas las técnicas de medida como son las tasas de natalidad, longevidad, mortalidad, 
etc. De esta manera se establece en el cuerpo lo que llama Foucault (2007): "una biopolítica de la población" (p.168).

Con todas estas medidas de control sobre la población es inevitable establecer conexiones entre el saber y las relaciones de poder, ya que es evidente que son complementarios, pues mientras más discursos de saber y supuesto bienestar de la población, más instrumentos de poder y vigilancia se deben implementar, de manera que el poder va circulando a través de los discursos de la vida diaria con el fin de hacer una población más controlada y productiva. Todo esto Foucault lo expresa (2007): "Habría que hablar de "biopolítica" para designar lo que hace entrar a la vida y sus mecanismos en el dominio de los cálculos explícitos y convierte al poder-saber en un agente de transformación de la vida humana” (p.173).

En esta relación del poder y el saber se hace necesario recurrir a la norma como la forma en la que el Estado lleva a preponderar la vida y evitar la muerte, lo cual lleva a establecer al interior de las sociedades instituciones donde se haga una separación entre lo que se considera dentro de la norma y lo que está separado de ella, dando como resultado lugares como la cárcel, el manicomio, el cuartel, la escuela, la correccional, etc.; lugares en los cuales el individuo es clasificado, vigilado, normalizado, curado, reprendido, formado, castigado, reformado. De esta manera mediante la inclusión forzada a cierta institución se inaugura un nuevo modelo de sociedad: la sociedad disciplinaria, basada en el orden y la norma y por lo tanto basada en el rechazo al otro, a la diferencia, a la alteridad.

Por otra parte la escuela de Frankfurt desde la teoría crítica planteaba la ciencia moderna como origen de la dominación, representante de esta escuela de pensamiento es Herbet Marcuse en su libro: El hombre Unidimensional (1993) trata de reconstruir históricamente el proceso de configuración de la ciencia moderna como poder de dominación. Por ello, dentro del marco abierto por el conocimiento moderno se da un proceso histórico en el cual, "los principios de la ciencia moderna fueron estructurados a priori, de tal modo que pueden servir como instrumentos conceptuales para un universo de control productivo autoexpansivo" (p.185). Por lo tanto, en el método científico está la base de un proceso de dominación efectivo, pues brinda "los conceptos 
puros" y los "instrumentos” (p.185) para efectuar una dominación cada vez menos violenta, pero más efectiva del hombre sobre el hombre, en un contexto ideológico marcado por la neutralidad de la razón teórica.

Por lo tanto, la neutralidad de la razón teórica efectúa la subordinación de la misma a la racionalidad práctica. Marcuse afirma que la tecnología no es sólo un medio de la dominación sino la dominación misma. El carácter represivo de la dominación se hace efectivo en la tecnología, subordinando la autonomía personal al proceso de autoexpansión capitalista, que de paso se nutre de la destrucción de la naturaleza.

Así mismo la tecnología la distingue Marcuse como la forma en que se expande la dominación, pues brinda la fórmula para "racionalizar" el universo cultural, social, económico y político. Bajo estas condiciones represivas, la tecnología se opone a la autonomía personal en la medida en que crea las condiciones propicias para la alienación, lo que para Marcuse (1993) se expresa:

En este universo, la tecnología provee la gran racionalización para la falta de libertad del hombre y demuestra la imposibilidad 'técnica' de ser autó-nomo, de determinar la propia vida. Porque esta falta de libertad no aparece ni como irracional ni como política, sino más bien como una sumisión al aparato técnico que aumenta las comodidades de la vida y aumenta la productividad del trabajo. (Marcuse, 1993, p.186).

La racionalidad tecnológica legitima la dominación, al mismo tiempo que la realiza, de manera que para Marcuse (1993): "Hoy, la dominación se perpetúa y se difunde no sólo por medio de la tecnología sino como tecnología, y la última provee la gran legitimación del poder político en expansión, absorbiendo todas las esferas de la cultura" (p.186). Este aparato técnico aumenta la comodidad y promueve las condiciones para continuar dependiendo de ella, por un creciente proceso de instrumentalización, el cual se ha transferido desde las cosas hasta las personas, de manera que la instrumentalización de las fuerzas humanas convierte a la dominación técnica en un proyecto histórico de dominación política, dando como finalidad que el individuo cada vez sea menos consiente de sí mismo y de su pensamiento. Adicionalmente la productividad represiva supone y alimenta el afianzamiento de la dominación como una condición normal de parte del dominado. 
Marcuse está convencido de que la racionalización moderna no puede ser otra cosa más que la expresión del dominio técnico sobre la naturaleza y el hombre y que no es ajena al sistema político y al contexto histórico en el cual está instalado, por lo tanto la ciencia no es independiente del sistema preestablecido de fines en el que se desenvuelve y para el que trabaja.

En entonces que la mutua implicación entre tecnología y poder político supone que, en medio de la irracionalidad última de los fines genéricos, existe una productividad universal, la cual sirve a los intereses del sistema global. La tecnología es el mecanismo por medio del cual se cosifican las relaciones, no sólo del trabajo sino también las de la vida cultural, por lo cual el individuo está atrapado en un sistema que abarca la totalidad de las actuaciones sociales. Esta máquina de dominación no deja fuera a ningún miembro de la sociedad, pues se devora hasta a quienes administran y manejan el poder.

\section{Cuerpo:}

Si desde la biopólitica el sujeto es continuamente vigilado, controlado y disciplinado, es en el cuerpo donde se reciben todas estas disciplinas y estrategias de control, de esta manera para Foucault el cuerpo se convierte en el territorio en el cual convergen todas las estrategias disciplinarias de la sociedad moderna, todas ellas en nombre de la razón, que para mantener el orden se vale de una cantidad de instituciones que en diversos momentos de la vida se encargan de mantener la vigilancia y control sobre el cuerpo del individuo, con lo cual se da paso a la formación de que llama Foucault en Vigilar y Castigar (2002): una "sociedad disciplinaria" (p.118), que distingue Foucault se da de una manera evidente durante el régimen victoriano que se preocupó por dar a cada cosa un lugar en función de la producción, tal como lo enuncia en la Voluntad de saber (2007): "Lo que no apunta a la generación o está transfigurado por ella ya no tiene sitio ni ley. Tampoco verbo. Se encuentra a la vez expulsado, negado y reducido al silencio" (p.10).

Es decir que todo comportamiento humano se entiende desde la racionalidad, como es propio de la cultura moderna, que proviene de Descartes; dando como resultado una continua oposición entre razón-sinrazón, y desde esta oposición se da entonces la forma como se trata a los individuos llevando a algunos de estos al encierro y a la clínica donde se busca corregirlos y mantenerlos fuera de los límites de la razón. 
Es en estos espacios donde el cuerpo se convierte en el receptor de innumerables disciplinas y la base fundamental de dispositivos que enmarcan la relación entre poder y saber, pues es necesario que el cuerpo se adapte a una sociedad perfectamente ordenada, pero esta adaptación lleva consigo que el cuerpo se desconozca como tal, es decir que tenga una ruptura entre sensibilidad y conocimiento y se haga dócil al sometimiento a políticas de control y vigilancia policial, social, económica, sanitaria, administrativa, etc. De manera que el cuerpo se convierte en un campo de fuerzas de dominio en continua disputa y tensión, pues ahora es visto como el territorio en el que el Estado tiene poder sobre la vida y el primer territorio en donde se puede hablar de una sociedad disciplinada con sistemas de control eficaces que Foucault llama en la Voluntad de Saber (2007): "procedimientos de poder característicos de las disciplinas: anatomopolítica del cuerpo humano" (p.168). Para que estas disciplinas sean eficaces Foucault (2007) entiende el cuerpo desde dos polos: cuerpo como máquina: donde se dan las estrategias correspondientes a la educación, valoración de acuerdo a sus aptitudes y su correspondiente integración a los sistemas de control para hacerlo más útil; y el cuerpo-especie: en él se toman en cuenta todos los procesos biológicos a fin de cuantificar los nacimientos, las enfermedades, las costumbres en cuanto a la salubridad, la mortalidad, etc.

De esta manera el cuerpo entonces se convierte en un cuerpo ideal, carente de discurso, vacío de subjetividad, lo que permite que sea manipulado, modelado, e integrado en dispositivos de poder sin ofrecer ningún tipo de resistencia. Es lo que identifica Foucault en Vigilar y Castigar (2002) como: "cuerpos dóciles" (p.180), es decir como el lugar donde el poder inscribe su anatomía política, resultado de las sucesivas manipulaciones y modelaciones bajo el mecanicismo disciplinario, lo cual lleva a la formación de cuerpos sometidos y útiles.

Siguiendo por la misma senda que traza Michel Foucault sobre la disciplina del cuerpo, encontramos la obra de Giorgio Agamben que expone en el Homo Sacer, desde el advenimiento de la política moderna como la politización de la vida humana, o en términos empleados por Agamben (2006): "el ingreso de la zoé en la esfera de la polis" (p.13). De tal manera que las estrategias políticas convirtieron en su objetivo la especie y el individuo, en cuanto simple cuerpo viviente. La política en el marco del poder como soberanía, conllevaba la reducción absoluta del sujeto a la instrumentalidad de un poder que lo convertía en nuda vida; o algo así como una 
especie de animalización del hombre llevada a cabo por medio de las más refinadas técnicas políticas.

Agamben apunta a considerar la política occidental, desde el inicio, como biopolítica, pues la política moderna se presenta como un desarrollo de este fundamento biopolítico originario, desde la oposición entre zôe y bíos, es decir, entre el simple hecho de vivir, común a todos los seres vivos, y una vida cualificada, propia de un individuo, grupo o comunidad. Esta dicotomía se presenta en la idea que prevalece en el mundo griego, según la cual la vida natural o "nuda vida" debe ser excluida del ámbito público y relegada al espacio invisible de lo privado, al terreno del oîkos. De lo anterior se desprende que hay una vida natural separable y distinta de la vida cualificada, de la existencia política. Se trata, de reconsiderar el sentido de la definición aristotélica citada por Agamben (2006): "la polis como oposición entre el vivir y el vivir bien" (p.16). De manera que se encuentra entonces una implicación de la nuda vida en la vida política.

Para Agamben (2006) el objeto de investigación no es solamente el sentido, los modos y las posibles articulaciones del "vivir bien" como finalidad o "télos de lo político (Agamben, 2006), de esta manera según Agamben, debido a esta concepción de la política como lugar en que "el vivir debe transformarse en vivir bien", es que puede entenderse en qué sentido la zôe, es decir, la vida natural, se incluye por exclusión en la vida de la polis, lo que expresa Agamben: el espacio de la nuda vida que estaba situada originariamente al margen del orden jurídico, va coincidiendo de manera progresiva con el espacio político, de forma que exclusión e inclusión, externo e interno, bios y zoé, derecho y hecho, entran en una zona de irreductible indiferenciación. (Agamben Giorgio, 2006, p.19)

\section{Homosexualidad:}

Sigmund Freud hace un análisis bastante profundo de la sexualidad humana en los Tres ensayos para una teoría Sexual; allí identifica a la persona que desea sexualmente como: objeto sexual y a la acción a la que impulsa el instinto sexual como: fin sexual. Es desde estos dos conceptos que Freud enuncia la homosexualidad, teniendo en cuenta que, según Freud (1981): “A la teoría popular del instinto sexual corresponde la poética fábula de la división del ser humano en dos mitades -hombre y mujer-, que tienden a reunirse en el amor" (p.1172), por lo tanto toda persona que tenga por fin sexual una persona de su mismo sexo se le denomina homosexual o 
invertido, de los que identifica varias conductas: -Invertidos absolutos: que tienen como fin sexual exclusivamente personas de su mismo sexo; - Invertidos anfígenos: los distingue Freud como hermafroditas y su objeto sexual puede ser uno u otro sexo; - Invertidos ocasionales: llegan a alcanzar satisfacción sexual con una persona de su mismo sexo, si por circunstancias no encuentran objeto sexual distinto. La conducta homosexual según Freud puede ser para toda la vida y puede ser tomada de la misma manera que tomaría su conducta un heterosexual o puede ser una cuestión circunstancial, también puede ser descubierta en la infancia o en algunos individuos es descubierta en la vida adulta o en la madurez, después de haber sido heterosexual a lo largo de su vida.

Freud (1981) define la homosexualidad, como: "El primer juicio sobre la inversión consistió en considerarla como un signo congénito de degeneración nerviosa; juicio fundado en que los observadores científicos la hallaron primeramente en individuos enfermos de los nervios o que producían la impresión de estarlo". (p.1174). Es así que se puede entender desde este autor que la homosexualidad es una enfermedad nerviosa y algo que se sale de todo lo que se considera normal en cuanto al deseo sexual.

Con respecto al objeto sexual en los homosexuales, Freud (1981) identifica: "el objeto sexual del invertido es el contrario al del normal. El hombre sucumbiría, como la mujer, al encanto emanado de las cualidades físicas y espirituales masculinas, y, sintiéndose mujer, buscaría al hombre" (p.1177), de manera que la persona abandona su sexualidad para comportarse como el sexo opuesto y llega a sentirse como uno (a) de ellos. Sin embargo para Freud no todos los homosexuales llegan a comportarse así y mantienen en el fondo una atracción por características secundarias del sexo opuesto, aunque lo materialicen en personas de su mismo sexo.

En lo que tiene que ver con el fin sexual de los homosexuales expone Freud que no hay un fin sexual establecido, único, ni definido ${ }^{2}$ y que el fin sexual para los homosexuales hombres es distinto para las mujeres homosexuales.

\footnotetext{
${ }^{2}$ Para Freud el fin último del deseo es la cópula sexual. P.1173
} 
Para Michel Foucault la homosexualidad se puede entender desde la expresión que él mismo utiliza en el volumen I de la Historia de la Sexualidad (2007): "puritanismo moderno" (p.11) y sus tres postulados de "prohibición, inexistencia y mutismo" (p.11), ya que este puritanismo llega a entender toda la sexualidad desde la represión que supone unos fines económicos y políticos en la vivencia y práctica de la sexualidad.

Se entiende entonces la homosexualidad desde la prohibición, para lo cual se debe partir de la identificación histórica que se ha hecho de la sexualidad y el pecado y como se normaliza la sexualidad solamente enmarcada en el matrimonio y con el específico de la procreación, de manera que toda expresión de sexualidad que esté por fuera del matrimonio y alejada de este fin se considera prohibida, lo que expresa Foucault (2007): "ser represivo y reprimir con particular atención las energías inútiles, la intensidad de los placeres y las conductas irregulares”(p.17).

Desde la inexistencia se entiende a partir de los discursos que tienen que ver con la sexualidad, pues el poder se expresa en las prácticas sexuales a través del discurso y por ende la forma de control que se ejerce sobre el mismo. Un ejemplo de esto lo da Foucault (2007): "la evolución de la pastoral católica y del sacramento de penitencia después del concilio de Trento" (p.26), de esta manera se comienza a hablar de sexo con una forma específica determinada por la religión católica, que por medio de la confesión se encarga de dar validez a palabras relacionadas con el sexo y a prohibir o restringir otras que se consideran relacionadas con lo que considera la religión católica "las insinuaciones de la carne" (p.27), con lo cual se invita a los fieles a confesar todos sus pensamientos, palabras y acciones que provengan de los deseos, como lo expresa Foucault (2007): "se plantea un imperativo: no sólo confesar los actos contrarios a la ley, sino intentar convertir el deseo, todo el deseo en discurso" (p.29), pero este discurso debe tener en cuenta unas palabras apropiadas y establecidas desde lo que se considera moralmente aceptable.

Así como se crean discursos sobre la sexualidad, también hay cuestiones relativas a ella que se condenan al silencio, como es el caso de la homosexualidad, pues esta estaría en las situaciones correspondientes a la discreción, como un asunto que es mejor callar y no hablar de él, de acuerdo a lo planteado por Foucault (2007): "no hay un silencio sino silencios varios y son parte integrante de estrategias que subtienden y atraviesan los discursos" (p.37). 
Este silencio se debe a que la homosexualidad se considera "contra natura" y por esto mismo es abominable, pues lo determinado por la naturaleza es la pareja heterosexual al interior del matrimonio. Sin embargo esta situación de silencio se rompe en el siglo XIX cuando la psiquiatría indaga por lo que llama Foucault (2007): "sexualidades periféricas" (p.56) en las cuales se encuentra la homosexualidad de manera que según Foucault (2007): "El homosexual del siglo XIX ha llegado a ser un personaje: un pasado, una historia y una infancia, un carácter, una forma de vida; asimismo una morfología, con una anatomía indiscreta y quizás misteriosa fisiología" (p.56), de manera que la homosexualidad abandona su silencio para convertirse en objeto de discurso de la medicina, la psicología, la psiquiatría, y hoy día la pedagogía, la misma política y el Estado que se interroga sobre cómo garantizar sus derechos e igualdad con respecto al resto de la población. 


\section{CAPITULO I \\ SEXUALIDAD Y CULTURA}

\subsection{La sexualidad en la cultura occidental:}

\subsubsection{La sexualidad en la cultura judía}

La cultura judía se basa en las enseñanzas de la Torah, la sexualidad para la cultura judía es muy importante, la actividad sexual es fundamental en la vida del ser humano, pero se encuentra acompañada de normas y preceptos que la orientan.

La sexualidad en el AT tiene una clara finalidad procreativa. El celibato o la soltería no eran muy aceptados, especialmente tratándose de una mujer. La sexualidad y el matrimonio tenían como finalidad clara la procreación, esta se consideraba en aquella sociedad un gran bien y una bendición de Dios, un regalo del Altísimo. De ahí leyes como el levirato ${ }^{3}$, que suponían garantizar la descendencia de los hijos de Israel, que era lo más importante para la sociedad. Bajo este contexto de fecundidad se pueden comprender las prácticas poligámicas de los patriarcas, quienes con el fin de procrear, tenían descendencia con más de una mujer, habitualmente eran esclavas o concubinas.

El deseo de toda mujer era desposarse y tener descendencia. La mujer es descrita poéticamente como "Tu mujer será como vid que lleva fruto a los lados de tu casa; tus hijos, como plantas de olivo alrededor de tu mesa" (Salmo 128, 3) "Multiplicaré tu descendencia como las estrellas del cielo" (Gn 26,4). Las referencias a la fecundidad y la descendencia son bastante recurrentes en el Antiguo Testamento y con frecuencia hacen parte de las promesas de Dios a sus fieles.

La virginidad no fue estimada por los judíos, salvo como punto de llegada al matrimonio, como regalo sin abrir para el marido. La pérdida de la virginidad implicaba una disminución del precio a pagar por el casamiento, y en consecuencia un peor matrimonio. Las relaciones sexuales

\footnotetext{
${ }^{3}$ Ley mosaica según la cual cuando un hombre casado moría sin descendencia, su hermano tenía que casarse con la viuda. (Dt 25,5)
} 
anteriores al matrimonio se consideraban una insensatez por parte de la mujer, que perdiendo su virginidad degradaba su valor matrimonial.

En cuanto a la poligamia, se encuentra que fue desapareciendo como costumbre en el pueblo judío, pues en los primeros libros de la Biblia los patriarcas del Génesis mantienen una sexualidad poligámica en varias oportunidades. Un ejemplo se encuentra en Gen 16,1: Abraham tiene relaciones sexuales con Agar su esclava, a pesar de estar con Saray su mujer; por lo tanto se puede decir que es una poligamia relativa, un concubinato aceptado y propuesto por Saray con el fin de favorecer la descendencia. En el texto de Gen 29, 15 Jacob tiene dos mujeres, Lía y Raquel, hay un doble matrimonio, con hijos diferentes e incluso más tarde tendrá hijos con su esclava Vila. Estas relaciones poligámicas se encuentran en narraciones anteriores a las de la Alianza, cuando las costumbres de los patriarcas son más cercanas a las costumbres de los pueblos cananeos.

En la revelación del Sinaí se adoptará la monogamia como forma habitual de vivir la sexualidad, con lo cual se subraya la monogamia como forma habitual hebrea. Las leyes del divorcio y del levirato, podrían ser una corrección de la poligamia, puesto que la norma del levirato, presente en Dt 25, 5, buscar dar descendencia en caso de morir sin tener hijos, lo que se puede considerar muy en el fondo como una poligamia aplicada a casos excepcionales.

En cuanto al divorcio (Dt 24,1) se indica como el hombre podía repudiar a su mujer por hallar algo en ella que le desagradara, lo que supone que la mujer queda en una situación de absoluta indefensión.

Otra prescripción importante era la relativa a la fidelidad conyugal, que estaba protegida por la Ley de Moisés. Se consideraba delito, falta muy grave, el adulterio, es decir las relaciones extra-conyugales o engaño en el matrimonio. Era tenido por un pecado muy grave contra Dios, con quien se había establecido una Alianza; y contra el cónyuge, que se consideraba el primer perjudicado. Las razones de ese perjuicio partían del precio pagado por el marido para contraer matrimonio, de tal manera que se consideraba un hurto y un abuso contra la propiedad del otro, siendo la condena semejante al homicidio y al robo. Ejemplo de esto se encuentra en Gn 20ss, donde Dios castiga a Abimelek por tomar a la mujer de Abraham, que aunque no sabía nada y 
peca por desconocimiento, se arrepiente, y trata de compensar a Abraham con propiedades. Algo parecido se encuentra en Gn 39, 7-9, cuando José rehúsa acostarse con la mujer de su amo, para no pecar. La prohibición Mosaica se encuentra en Ex 20, 17: "No codiciarás la casa de tu prójimo, ni codiciarás la mujer de tu prójimo, ni su siervo, ni su sierva, ni su buey, ni su asno, ni nada que sea de tu prójimo", o en Ex 5, 18: "No cometerás adulterio".

El castigo está en Dt 22, 22: "Si se sorprende a un hombre acostado con una mujer casada, morirán los dos; el hombre que se acostó con la mujer y la mujer misma. Así harás desaparecer de Israel el mal". El castigo por adulterio es la pena de muerte que posteriormente Jesús corrige al perdonar a la adúltera "aquel de vosotros que esté sin pecado, que le arroje la primera piedra" Jn 8,7 .

En cuanto al matrimonio, este era habitualmente contratado por los padres, normalmente atendiendo a razones políticas, sociales o económicas. Estos se realizaban en edades muy tempranas alrededor de los 15 a los 20 años de edad, tanto para mujeres como varones. No obstante también aparecen casos de jóvenes enamorados, como es el caso la hija de Saúl que se enamora de David $(1$ Sam 18,20) y se casan tras pagar la dote el propio David.

La prostitución es desaconsejada por considerarla seducción y engaño por parte de la mujer para el hombre: "el hombre es conducido y seducido a ella y va como buey al matadero, atrapado por una trampa de caza" (Prov 7,4). Las prostitutas están consideradas socialmente muy mal, pues se les considera pecadoras públicas.

Por otra parte son condenables en el Antiguo Testamento conductas como el incesto, las relaciones entre padres con hijos o nietos, con hermanos o con la suegra, al igual se castiga el bestialismo, las relaciones sexuales con animales. (Dt 27, 20-23). Igualmente se condena la homosexualidad: "No te acostarás con varón como con mujer, es una abominación" (Lev 18, 22), esta práctica no estaba mal vista en el mundo griego, como se verá más adelante, donde era corriente que además de la mujer se tuviera algún esclavo joven, con el que mantener relaciones.

Aunque la legislación judaica es rigurosa con respecto a los temas sexuales permite dentro del matrimonio las relaciones sexuales no solo para la reproducción sino también para recreación, 
ya que el sexo dentro del matrimonio es mitzvá: precepto divino, así la tradición judía establece que es necesario conocer los misterios de la sexualidad para comprender la belleza y misterios de la ley de Dios.

Se observan también cuestiones relacionadas con la pureza o impureza como ritual, así se encuentra que la menstruación de la mujer y el flujo hacen a la mujer impura, y convierten todo lo que toca en impuro; según la legislación del Levítico 15 se permanecía en impureza hasta la tarde teniendo que lavarse en la mikve $e^{4}$, cuyo rito de lavado garantiza la pureza de la mujer para tener relaciones con su esposo. En el mismo sentido, tras el parto la mujer quedaba impura varios días en función del sexo del hijo, siete días después del nacimiento de un varón y treinta y tres días después del nacimiento de una niña. También las poluciones seminales fuera de la relación marital hacían que el varón permaneciera impuro, incluido todo lo que tocara.

La masturbación se puede considerar negativamente, aunque no hay ningún texto suficientemente claro al respecto, sin embargo en Gn 38, 6-10, aparece Onán que se niega a cumplir la ley del levirato eyaculando fuera de la mujer. Se quería así desentender de la posible descendencia, cosa que a Yahvé le pareció mal. Este relato de Onán se ha utilizado para condenar la masturbación, y así pasó al cristianismo.

En los libros sapienciales se encuentran recomendaciones sobre la fidelidad conyugal: "Gózate en la mujer de tu mocedad, cierva amable, graciosa gacela; embriágate en todo tiempo sus amores, su amor te apasione para siempre. ¿Por qué apasionarle, hijo mío, de una ajena, abrazar el seno de una extraña?" (Prov 5, 18-20), con respecto a este tema hay mayor flexibilidad para el hombre y rigidez para la mujer, aun si la infidelidad se da desde una violación: "Si un hombre seduce a una virgen, no desposada, y se acuesta con ella, le pagará la dote, y la tomará por mujer, y si el padre de ella no quiere dársela, el seductor pagará el dinero de la dote de las vírgenes" (Ex 22, 15-16). Es decir que si la infidelidad es causada por el marido no se le va a castigar y bastará con pagar dinero, pero si la mujer es la infiel la pena es inexorablemente la muerte por lapidación. Se hace evidente entonces la desigualdad y la posición ventajosa del

\footnotetext{
${ }^{4}$ pequeña alberca que está unida a una fuente de aguas naturales que fueron recolectadas en forma natural (Ilamada "otzar"), a las que se les agrega luego agua limpia y templada. Westheimer, R.,Jonathan, M. (1997). Sexo divino, Sexualidad en el Judaísmo. Pg.122.
} 
hombre sobre la mujer, a tal punto que él tiene la decisión de acusar a la mujer y aplicarle la sanción, sobre todo en la pena de adulterio ya que esta pena tiene que ver más con la propiedad y la posesión de los bienes que con la castidad.

En conclusión se puede comprobar que la sexualidad como experiencia vital fue apreciada y sirvió en ocasiones para explicar el amor de Dios a su pueblo. En Oseas se hace la comparación del amor despreciado en el adulterio o la prostitución con el amor de Dios por su pueblo. La sexualidad se convierte en un signo del amor profundo de Dios. Algo parecido sucede en el profeta Jeremías, quien emplea la imagen del amor juvenil como reflejo de la ternura de Dios; o en Ezequiel 16 y 23, donde se encuentran historias de amor y sexualidad, de pecados y adulterios, espejos del perdón y la misericordia de Dios, siempre dispuesto a encontrarse con su pueblo. También en este sentido se encuentra en el Cantar de los Cantares la relación de amor de una pareja, empleado como paralelo al amor de Yahvé a su pueblo. Un amor que debe ser único, igualitario, permanente y fiel, fuerte y libre. La sexualidad era muy valorada en el matrimonio y considerada como un hecho fundamental de la vida humana, y muy prohibida fuera del mismo, es en este sentido que la moderación sexual y el autocontrol son esencia de la santidad; de igual manera la soltería y el celibato no son aceptados en el antiguo testamento ni en la tradición judía.

\subsubsection{La sexualidad en la cultura griega}

Michel Foucault en el volumen II de su obra: La historia de la sexualidad: El uso de los placeres (2007) hace un acercamiento de cómo los individuos llegaron a indagar sobre el estado de sus propios deseos y el contexto de la Grecia clásica y grecolatina de los primeros siglos de la era cristiana.

En el capítulo 1: La problematización moral de los placeres: Encuentra el autor que en los griegos no se haya una palabra que encierre todo el término "sexualidad", pero si disponían de varias palabras que designan la relación o el acto sexual: Synousia, homilia, plêsiasmos, misis, ocheia, sin embargo utilizaban el término ta aphrodisia que determina más o menos lo mismo que los latinos traducen por venerea como "Cosas" o "placeres del amor", "relaciones sexuales", "actos de la carne", "voluptuosidades". 
La conducta sexual se ve determinada por la dietética que se ocupa del tema del cuerpo, la económica con el tema del matrimonio, la erótica con el tema de los muchachos y la filosofía con el tema de la verdad.

1. Aphrodisia: El contenido más elemental del concepto Aphrodisia es "actos u obras de Afrodita" (p.37), según definición de Hesiquio, citado por Foucault (2007). Sin embargo se trata de actos, gestos, contactos, que buscan cierta forma de placer. Sus elementos están fuertemente ligados unos con otros. Para Aristóteles sólo los placeres del cuerpo revelan la intemperancia, akolasia. El contacto se da con la boca, la lengua y la garganta en cuanto a comida o bebida y con otras partes del cuerpo con respecto al sexo. La epithymia como el deseo, el movimiento hacia lo que "da placer", ya que como lo enuncia Foucault (2007):"el objeto del deseo es lo agradable" (p.42), dando origen a una ontología del comportamiento sexual que busca unir actos, placeres y deseos. Tal es lo fundamental de la experiencia ética de las aphrodisia. Lo que distingue a unos de otros hombres es la intensidad de la práctica. En Platón se da la diferencia "conforme a natura" o "contra natura". Las prácticas contra natura no se explican como efecto de una naturaleza anormal. La inmoralidad de los placeres del sexo radica en la exageración, la demasía y el exceso. Tal la línea de partida moral del comportamiento sexual, la gradación cuantitativa.

En la práctica sexual existen dos polos: la del sujeto y la del objeto, cada uno de ellos tiene un papel y una función: los actores pasivos corresponden a las mujeres, esclavos y muchachos y los actores activos son los hombres adultos y libres. El exceso y la pasividad son las dos formas mayores de inmoralidad en la práctica de las aphrodisia. Así entonces ni el acto ni el placer son malos, todo lo contrario, ya que restauran una forma consumada de ser del hombre.

El placer ejerce una presión sobre el deseo, haciendo que la actividad sexual se desborde, la fuerza del placer es excesiva, lo moral es enfrentar esta fuerza, dominarla y asegurar su economía. En la cultura antigua se asocia fácilmente la moral de la mesa y la moral del sexo. Así la problematización moral en la época clásica, es muy similar ya que se ponen en relación la dinámica de los placeres, las relaciones y los actos.

2. Chrêsis: Se relaciona en general con la actividad sexual desde la categoría del tiempo advirtiendo que existen momentos del año o de la vida en que es buena la actividad sexual, 
considerando desde el uso de los placeres una triple estrategia: la de la necesidad, la del momento y la del estatuto.

1. La estrategia de la necesidad:

La necesidad es el principio rector, pues el hombre se encuentra inmerso en cantidad de necesidades que debe suplir, como son la de comer, beber, satisfacer sus apetitos sexuales, con respecto a este último, se trata de mantener el placer por la necesidad que se provoca por el deseo y es mediante la espera y la privación que se logra dicho placer. Para lo cual se hace necesario cultivar la templanza como aquello que en palabras de Sócrates, citado por Foucault (2007) es "capaz de hacernos soportar las privaciones, y es por esto mismo capaz de hacernos gozar" (p.56).

2. La estrategia del momento oportuno, el kairos:

En el uso de los placeres, la moral es un arte del momento. Para los griegos es muy importante dar un momento para cada cosa y un uso debido de las cosas, lo cual es importante desde el plano moral y también desde la ciencia y la técnica. Se dan entonces diversas razones dietéticas para no comenzar muy joven los placeres, al igual que existen argumentos de decencia, motivos religiosos como realizar la práctica sexual en la noche, con el fin de no interferir las prácticas religiosas del siguiente día. De otra parte se identifica el incesto como una consecuencia de desconocimiento del tiempo. De manera que encontrar el momento oportuno para la práctica sexual garantiza un equilibrio entre el placer y las actividades que cada hombre debe desempeñar. Foucault cita la frase de Platón (2007): "cuando es debido y en tanto sea debido" (p.56), con la cual se puede establecer la forma como los griegos entienden que el momento y la medida adecuada son la forma para alcanzar la felicidad, al igual que al usar los placeres, como lo argumenta Foucault (2007): “el arte de hacer uso de los placeres" (p.56).

3. El uso de los placeres se modula según quien lo usa y según el estatuto que le convenga:

Es el amor al honor y la alabanza que permite sobrellevar peligros y privaciones, encontrando que la templanza que permite el uso apropiado de los placeres es propia de quienes tienen rango, posición, responsabilidad en la ciudad. Distingue Foucault la sôphrosynê como la diferencia que se establece entre quienes mandan y quiénes obedecen. En el estado temperante, las pasiones de la multitud viciosa están dominadas para Foucault (2007): "por las pasiones y la 
inteligencia de una minoría virtuosa"(p. 60), la aplicación de este equilibrio de los individuos temperantes es la technê, que no es una norma de acción, sino una actitud que modula e individualiza la acción.

3. Enkrateia: Se define como la forma de relación con uno mismo, desde una "actitud" que permite un buen uso de los placeres, como una forma activa de dominio. Domina los placeres y los deseos, lucha y vence, su mérito es mayor en tanto su lucha es más fuerte. Este término se utilizó cercano a Sôphrosynê incluso alternándolas sin embargo se puede decir de ella que es el estado que asegura que la conducta sea acorde al deber, ante hombres y dioses, hace al hombre piadoso, justo y valeroso. El dominio que ejerce la enkrateia requiere un esfuerzo y una dinámica de control continua sobre sí mismo, como lo expresa Foucault (2007): "la dinámica de un dominio de uno mismo por sí mismo y al esfuerzo que requiere” (p.63). Esta continua práctica de dominio implica una relación agonística, en primera medida con los adversarios y luego con uno mismo.

1. Relación agonística con los adversarios: Como los animales, tenemos apetitos inferiores, que pueden hacernos esclavos; ante lo cual se hace necesaria una continua lucha por el poder entre la temperancia y los apetitos inferiores, entre dominarlos o dejarse dominar por ellos, así para Foucault (2007): "La larga tradición del combate espiritual, que había de tomar tantas formas y tan distintas, se había claramente articulado ya en el pensamiento griego clásico" (p. $65)$.

2. Relación agonística con uno mismo: La lucha que se sostiene por el poder es una lucha entre uno y uno mismo, pues los apetitos inferiores se encuentran dentro de cada uno, de manera que para Foucault (2007): "luchar contra "los deseos y los placeres" es medirse con uno mismo" (p.66).

3. El término debe ser la victoria: El temperante no carece de deseos, y eso hace que su continua lucha sea más meritoria pues es capaz de llegar a dominarse a sí mismo, lo cual expresa Foucault (2007) citando a Aristóteles en la Ética nicomaquea "el temperante no es aquel que carece de deseos, sino aquel que desea "con moderación y no más de lo debido ni cuando no se debe" (pg.68). Para llegar a alcanzar la temperancia el sujeto continuamente establece consigo mismo relaciones de "dominación-obediencia", "mando-sumisión", "señorío-docilidad", a lo que se le da el nombre de: 
4. La forma heautocrática: Está representada por el coche con caballos y cochero de Platón, el niño y el adulto de Aristóteles, de manera que así como el niño debe vivir bajo la guía de su tutor, el temperante debe dominar, como a sus servidores, a sus deseos, así como se domina en la casa. De otra parte siguiendo el modelo de la ciudad de Platón se establece que la virtud individual se estructura al igual que la ciudad.

5. Para la lucha es necesario entrenarse: La mathêsis como la relación consigo mismo no basta para dominarse sin una askêsis como el entrenamiento fuerte tanto para el cuerpo como para el alma. El dominio de sí y de los demás tiene la misma forma para el gobierno de una casa o de una ciudad. Formar las virtudes personales enkrateia es igual que formarse para superar y dirigir a los demás.

La askêsis moral como entrenamiento práctico, es parte de la paideia que desde la infancia, forma la virtud, inspira el deseo de ser un ciudadano cumplidor; que manda y obedece según la justicia del hombre que tiene que desempeñar un rol en la ciudad. La askêsis no es una práctica singular, sino una repetición continua de lo que se va aprendiendo con el objeto de ser señor de las propias pasiones, dando como resultado una vida virtuosa, para Foucault (2007): "la vida del hombre "libre" en su sentido pleno, positivo y político del término". (p.76).

4. Libertad y verdad: El buen uso de los placeres asegura la felicidad y el buen orden de la ciudad, pues para que esta alcance la perfección es necesario que los ciudadanos sean virtuosos y por lo tanto sean libres, pues se han dominado a sí mismos. También con respecto a la ciudad se hace alusión a quien ejerce el poder en ella, pues quien ha aprendido a dominarse a sí mismo es quien tiene las cualidades perfectas para gobernar a los demás, pues no abusará de su poder y por lo tanto no violentará a sus súbditos.

Esta representación del verdadero hombre libre como quien es capaz de dominar, afirma Foucault (2007): “es el carácter "viril” de la templanza" (p.80), pues tanto en la casa como en la ciudad el hombre es quien ostenta el poder y desde este ejercicio de dominación respecto de uno y respecto de los demás como dominio de jerarquía y autoridad es de donde se desprende un modelo de virilidad social, en un contexto de virilidad ética, que autoriza para el hombre una virilidad sexual. 
En cuanto a la mujer si quiere ser temperante debe ejercer virilidad respecto a sí misma y aceptar su papel desde el modelo de dominación ejercido por el hombre. De otra parte la intemperancia es comparada a la pasividad y por consiguiente a la femineidad del tal forma que el hombre que no domina sus placeres, es femenino. Para los griegos el hombre que se deja llevar por sus propios deseos puede llegar a tener gusto por los dos sexos lo cual constituye la negatividad ética por excelencia, que para Foucault (2007) implica: "ser pasivo respecto de los placeres" (p.83).

Quien se comporta de forma intemperante se comporta de acuerdo a la ignorancia, de tal forma que la relación con el logos en el uso de los placeres para los griegos ha sido vista desde: la templanza: sometimiento de todos los deseos al logos de acuerdo a los momentos y necesidades, de tal forma que la relación con la verdad convierte el actuar diario en lo que denomina Foucault (2007): "una estética de la existencia" (p.87) entendida desde el uso moderado y oportuno de los placeres.

Es claro que para los griegos el uso de los placeres no se determina de acuerdo a la ley o a la norma establecida por la cultura, sino que se determina desde una forma de dominarse totalmente a sí mismo como construcción del sujeto moral y en relación con el dominio de sí mismo, el momento y el uso adecuado y medido de las cosas.

En el capítulo 2: La dietética, plantea Foucault una paradoja aparente: Los griegos practicaron, aceptaron y valoraron relaciones entre hombres y muchachos mientras los filósofos edificaron una moral de la abstención. Por lo tanto los griegos admitieron que los hombres casados buscaran placeres sexuales fuera del matrimonio y los filósofos concibieron la fidelidad a la esposa.

Los griegos nunca creyeron que el placer sexual fuera un mal. Los médicos se inquietaron por la salud, por lo tanto diseñaron un régimen para reglamentar una actividad reconocida como importante para la salud al cual se le denomina "Dietética".

\section{Del régimen en general}


Se plantea la dietética como el origen de la medicina, ya que determina qué alimentos pueden consumir los que se sienten con algún tipo de dolencia, pero por el cambio en las costumbres de vida, el sentido de la dietética también cambió y esta aparece como medicina para tiempos de la molicie. La "dieta", se constituye como el régimen que debe determinar de forma fundamental la conducta humana.

1. El valor casi canónico del régimen: Cita Foucault (2007) el libro VI de las Epidemias de Hipócrates, en el que se miden los ejercicios (ponoi), los alimentos (sitia), las bebidas (pota), los sueños (hypnoi) y las relaciones sexuales (aphrodisia) (Foucault, 2007), para llegar a deducir que el ejercicio de todos ellos debe ser "medido", para tener así un buen cuidado del cuerpo.

2. El régimen establece una medida: Fija lo que está y se debe realizar en justa medida. El régimen físico, según Platón, citado por Foucault, se da según una estética general de la existencia que busque equilibrio corporal según la jerarquía del alma. Existe un peligro por el "exceso atlético" llevando desarrollo exagerado del cuerpo y el exceso "valetudinario" o excesiva atención en todo momento, al cuerpo y a todos los males.

3. La dieta hace útil y feliz a la vida: La dietética es un arte estratégico, responde de manera útil, a las circunstancias.

4. El régimen se dirige al alma y le inculca principios, Sócrates expresa que un hombre de bien sabe lo que es útil y exhorta, según lo cita Foucault (2007): a "mirar por su salud"(p.101) y a tener una atención vigilante de uno mismo.

\section{La dieta de los placeres:}

La dietética establece la práctica sexual como actividad a la que debe darse libre curso en conjunto o ponerle freno según referencias cronológicas. Foucault (2007), cita a Hipócrates quien considera que son la alimentación y los ejercicios los dos factores fundamentales del régimen y explicando que la actividad sexual no aporta al cuerpo sino que tiene efectos: adelgazamiento por evacuación, -calentamiento por ejercicio (ponoi) y eliminación de líquido húmedo y-consumición de las carnes por el ejercicio. Además como parte de este régimen establece un calendario de salud según un almanaque de estaciones que regula las aphrodisia, fija lo conveniente de relaciones sexuales frecuentes para hombres de más edad y de los placeres sexuales según variaciones estacionales evocando principios generales de equilibrio. De manera 
que el régimen no fija ni cantidades ni ritmos, sino que trata la práctica sexual como una “actividad" que se debe practicar de acuerdo a referencias cronológicas.

\section{Riesgos y peligros:}

Como régimen de las aphrosidias, modera la práctica, modula el uso de los placeres según el estado del cuerpo y las circunstancias externas, sin embargo la vigilancia hacia la práctica sexual, para Foucault se realiza por dos razones:

1. Consecuencias del acto sobre el cuerpo del individuo: Los griegos juzgaban que la actividad sexual era más provechosa para algunos organismos y menos para otros, sin embargo para muchos de ellos esta actividad es más nociva que provechosa para la salud. Foucault (2007) cita a Pitágoras cuando se le preguntaba por el momento propicio para el amor: "cuando uno quiere debilitarse" (p.110), de igual manera, cita a Aristóteles que cree que el cerebro es de los órganos que más se resiente por el acto sexual, pues tal acto tiene un efecto de enfriamiento. Los griegos entendían que las enfermedades relacionadas con el sexo se dan como consecuencia del exceso. La abstinencia en los hombres es conservación de fuerzas, acumulación y concentración y esta no perjudica. En cambio las mujeres necesitan del acto sexual para los derrames.

2. Inquietud por progenie: Cita Foucault (2007) a Platón en las Leyes, pues fija una serie de cuidados a raíz del primer acto sexual entre cónyuges, explicando que es un dios el que da el origen, por lo tanto se debe en la pareja tener precauciones porque no se sabe en qué momento el dios estará prestando su ayuda para la procreación. Uno de estos cuidados es no procrear en estado de embriaguez para asegurar la más bella descendencia, al igual que tener en cuenta la edad correcta de procreación tanto del hombre como de la mujer para asegurar la salud niño.

\section{El acto, el gasto, la muerte:}

Si bien los griegos no encuentran el acto sexual como malo, pues no hay descalificación ética en él, los médicos y filósofos si lo encuentran inquietante. Para Foucault (2007) tal inquietud radica en "que en la actividad sexual se reúnen el dominio, la fuerza y la vida del hombre" (p.117).

- La violencia del acto: La actividad sexual conlleva también algo de mal pues se pasa por diversos estados de excitación e incluso se llega a decir que se llega a la muerte después de los 
placeres y se le llega a comparar entonces con un mal menor, por tanto se puede decir que toda la excitación del acto sexual implica en sí misma violencia por la agitación que origina en el cuerpo.

- El gasto: el origen del semen fue un tema de discusión entre los filósofos y los médicos pues para unos y otros era inquietante como el semen era capaz de transmitir la vida y que diera vida a otro ser humano. De tal manera que esta simiente sale de la misma vida del hombre, por eso se considera sumamente valiosa, llegando a considerarse en el Timeo, citado por Foucault (2007) como "la bisagra del cuerpo y del alma, de la muerte y de la inmortalidad" (p.123). Por tanto el acto sexual es costoso porque expulsa el semen extraído de todo el organismo tras un largo proceso de elaboración.

- La muerte y la inmortalidad: Hay un vínculo entre los placeres sexuales y la reproducción, de hecho esta se plantea como su finalidad y así llega a ser el escape de la muerte, pues en la descendencia se da la sobrevivencia de la especie, en palabras de Foucault (2007): "la actividad sexual se inscribe pues en el horizonte amplio de la vida y de la muerte, del tiempo, del porvenir y de la eternidad" (p.127).

En el capítulo 3: La económica: Se da inicio a la sabiduría del matrimonio donde se plantea el tema del comportamiento del marido al interior del matrimonio, tema en el que se puede encontrar que para los griegos no fue una cuestión de preocupación tener relaciones sexuales fuera del matrimonio, para lo cual Foucault (2007) cita a Demóstenes: "Las cortesanas existen para el placer; las concubinas, para los cuidados cotidianos; las esposas, para tener una descendencia legítima y una fiel guardiana del hogar" (Contra Neera, 122). (p. 132) de donde concluye que las funciones en cuanto al placer están bien determinadas y en la Atenas clásica las -esposas-, están ligadas por su situación jurídica y social y tienen una función en el hogar más no aparecen como fundamentales en el placer sexual del matrimonio, toda su actividad sexual se sitúa al interior de la relación conyugal y su marido es compañero exclusivo, lo cual se regula con leyes severas como prohibir a la mujer adúltera aparecer en ceremonias de culto público, de manera que la mujer que no respete la exclusividad de su marido será objeto de escarnio público. Mientras que el hombre no está ligado sexualmente sólo a su mujer, y tener relaciones solamente con ella no era parte de sus obligaciones, pero si está imposibilitado de contraer otro matrimonio, entablar relaciones con mujeres casadas o que estén bajo la tutela de su padre, pues se constituye un delito contra la autoridad masculina de la que depende la mujer, más no una falta contra su 
esposa, de tal manera que según Foucault (2007): “el matrimonio de un hombre no lo liga sexualmente" (p.135). Por lo tanto la sexualidad de hombre y mujer en el matrimonio no está basada en principios de corresponsabilidad y reciprocidad, ya que la verdadera función del matrimonio era ligar las familias de los esposos y por supuesto procurar una descendencia. Es evidente que al reflexionar sobre el matrimonio se reflexiona sobre el oikos, la casa y el hogar por encima de la conducta de los esposos, aunque si se le pide al esposo un cierto modo de comportarse, sobre todo con respecto a sus hijos. Para ilustrar lo anterior, Foucault da el ejemplo de:

\section{El hogar de Iscómaco}

Jenofonte en su Económica establece un tratado de la vida marital, es la forma como se administra el patrimonio y los medios para llegar a este fin, pero sobre todo es el arte de mandar y esto se hace desde la forma de dirigir el oikos, lo cual constituye ya mandar, labor que no considera distinta para la casa y la ciudad. En el texto al hablar de oikos no se hace referencia solamente al hogar sino que se incluyen también las tierras y todos los bienes que están fuera de la casa, pues según Jenofonte, al citarlo Foucault (2007): "la casa de un hombre es todo lo que llega a poseer” (p.141), por lo tanto el mandar implica un ejercicio donde el hombre debe desempeñar varias actividades que también le dan posibilidad de dirigir en el plano político o militar. En esta tarea de dirigir su casa el hombre no está solo pues la mujer es quien se encarga directamente de manejar sus propiedades, pero esta tarea la desempeña ella según la forma como el marido le haya enseñado a hacerlo. Esta es la enseñanza que ilustra Foucault de Iscómaco que tomó una muchacha demasiado joven por esposa y debió formarla a fin que ella se ocupara de su casa y él pudiera sobresalir en otros oficios.

1. El principio del matrimonio: El matrimonio en su origen se da desde una simetría pues el hombre puede decidir por sí mismo con quien casarse, mientras que la familia decide por la muchacha, al tiempo que el matrimonio tiene la doble finalidad de la casa y los hijos, lo cual implica para la mujer que antes que lleguen los hijos es necesario que ella sea una buena ama de casa. Por tanto el matrimonio se establece para Foucault (2007): "por la mediación de una finalidad común, que es la casa” (p.145) y desde esta que se dan los papeles de cada uno de los miembros de la pareja.

2. Funciones en la familia: Ya que la casa es el lugar donde se aprovisiona la familia para vivir es tarea del hombre llevar los bienes a la casa, como es de la mujer mantener y distribuir 
según las necesidades, por lo tanto marido y mujer organizan su actividad de forma diferente, como diferente es el empleo del tiempo, pues por las necesidades del oikos, cada cónyuge tiene una naturaleza, actividad y lugar diferente, Nomos significa la práctica regular según las intenciones de la naturaleza, práctica que permite que se sostengan uno al otro, así el atentar contra esto, es atentar contra la naturaleza.

3. Parquedad sobre las relaciones sexuales: Según Foucault el texto de Jenofonte no entra en descripciones en cuanto al comportamiento sexual de los miembros de la pareja y el contrario considera que el dominio de sí es lo que da valor a la vida de la pareja. Por tanto no es necesario utilizar adornos ni maquillaje, porque estos constituyen elementos de engaño entre la verdad y el placer, pues el marido conoce a su mujer tal como es, pues la ve todos los días.

De esta manera el matrimonio, se llega a ver como una comunidad de bienes en la que cada cual olvida lo que aportó, tanto de prosperidad de patrimonio, como de cuerpos, por lo tanto los cónyuges no deben tratar de engañarse uno al otro respecto del cuerpo y es allí en donde reside la verdadera atracción sexual, pues desde la naturalidad de pareja es que se dan las relaciones sexuales.

Al igual la estabilidad de la pareja se da desde la capacidad que tenga la mujer de administrar la casa como una comunidad de bienes "koinonia” y así se garantiza la fidelidad del marido en cuanto al reconocimiento de los privilegios de la mujer en el matrimonio, y esta es la fidelidad del marido sobre la exclusividad sexual que el matrimonio impone a la mujer.

\section{Tres políticas de la templanza}

Cita Foucault tres textos: las Leyes o Reglas de Platón, un texto de Isócrates sobre el matrimonio, un tratado de la Económica de Aristóteles; en los que se recomienda al marido: moderación sexual como base de la regulación política, como una auto-imposición del hombre sobre sí mismo, una autolimitación reflexionada del propio poder del hombre.

1. En las leyes se establecen algunas regulaciones coercitivas:

- Que los ricos eviten casarse entre sí, por ventaja para el Estado.

- Que los jóvenes no tengan relaciones fuera de la esposa cuando sea tiempo de procrear. 
- La ley no es el mecanismo más adecuado y por lo tanto se deben tener en cuenta los instrumentos de persuasión para conseguir los efectos:

1. la opinión en cuanto a temas como el incesto.

2. la gloria tomando como ejemplo la abstención de los atletas para conseguir la victoria.

3. el honor del ser humano ya que no es el hombre un animal de manada y en el momento de procrear necesita alejarse con su pareja (Foucault, 2007).

4. la vergüenza

Es la relación del individuo consigo mismo: respeto, vergüenza, honor o gloria, son virtudes impuestas a la obediencia y tienen como fin facilitar una legislación para que los esposos cumplan con una finalidad, como lo expresa Foucault (2007): "ser progenitores de nuevos ciudadanos" (p.156), lo cual tendrá como resultado el procurar el equilibrio de la ciudad.

\section{La templanza y el ejercicio del poder político:}

Nuevamente se hace alusión a la conducta personal en lo que tiene que ver con el dominio de sí mismo y el gobierno, al igual que la forma como se gobierna la casa para poder gobernar una ciudad. Esta forma de comportarse de parte del gobernante le da la autoridad para exigir un comportamiento igual de parte de todos sus gobernados ya que al estado le sirve la incitación general a la virtud y el modelo contra el relajamiento.

\section{La Económica atribuida a Aristóteles:}

Lo cita Foucault como un manual del amo en el que se señala como su primera preocupación: su esposa, entonces cita la Ética a Nicómaco que presenta al hombre como un ser destinado a vivir en pareja, y allí mismo se dan unas funciones específicas a los cónyuges, así como la planeación de la economía familiar, pero a pesar de esta responsabilidad compartida los miembros de la pareja no se encuentran en igualdad de condiciones y la forma política de dicha desigualdad es la aristocracia. Igualmente cita la Ética a Eudemo, donde Aristóteles dice que la relación entre padres e hijos no puede ser justa, porque éstos no son independientes. Tampoco lo es la relación entre amos y siervos, salvo en cuanto se refiera la justicia económica e interna de la casa. Respecto del hombre y la mujer, su relación se acerca a la de la justicia política (Foucault, 2007). Por lo tanto en este contexto de una distribución desigual de poderes es donde el marido 
debe conceder privilegios a su mujer y esto lo puede hacer solamente desde su propia moderación y dominio de sí.

En el capítulo 4 dedicado a la erótica plantea Foucault lo que denomina:

\section{Una relación problemática}

Para los griegos un tema que si representaba inquietud era tener costumbres relajadas, es decir no resistirse a las mujeres ni a los muchachos. Se puede decir que eran bisexuales sin que esto implique una doble estructura del deseo, pues para Foucault (2007): "Los griegos no oponían, como dos elecciones exclusivas, como dos tipos de comportamiento radicalmente distintos, el amor del propio sexo y aquel del otro" (p. 172) de tal manera que se permitían una libre elección, pues la belleza no dependía del sexo, el apetito busca esa belleza. El apetito sólo es más noble en cuanto se dirige a lo más bello y honorable. Cita Foucault a Jenofonte en el Banquete, que refiere que el amor más antiguo, noble y razonable sólo se hacía con el sexo masculino. Elegir una muchacha o un muchacho no tiene una doble forma de deseo, sino una decisión personal. Amar a los muchachos era una práctica libre, legal y aceptada por la opinión de los ciudadanos libres.

1. Las reflexiones filosóficas y morales sobre el amor masculino no cubren todas las relaciones posibles: Las relaciones entre jóvenes adolescentes eran naturales. Asimismo se citan sin vergüenza relaciones entre hombres que se hayan prolongado a lo largo de la vida.

2. Los moralistas están animados por una inquietud pedagógica: Se establecen los papeles:

- El erasta: Toma la iniciativa, persigue, tiene derechos y obligaciones, muestra y modera su ardor, regala y sirve, tiene funciones que le dan derecho de esperar una justa recompensa.

- El erómeno: Es amado y cortejado, no cede con facilidad, no acepta demasiados homenajes, no da sus favores por interés ni alocadamente, valora a su compañero, reconoce todo lo que el amante hace por él.

3. La vida matrimonial es otro foco de interés e interrogación: Tomar algo a la fuerza del enemigo es muy placentero, mientras que de los muchachos, lo más dulce, es lo que se da voluntariamente.

4. La cuestión del tiempo: El cuerpo masculino entre los griegos es bello y ya no se trata aquí de encontrar el mejor momento para tener actos sexuales, la preocupación aquí es encontrar 
a partir de qué momento un muchacho ya es demasiado mayor para mantener una relación amorosa o para que el erasta lo corteje.

5. Reflexiones sobre el amor: Eros une a los seres humanos, independientemente de su sexo. Entre cónyuges es el oikos lo que fija los principios de la conducta. Entre un hombre y un muchacho, independientes ambos, se rigen según la naturaleza de su propio movimiento que los une con afecto recíprocamente.

\section{El honor de un muchacho}

1. En los textos de Platón y Jenofonte hay una preocupación que según Foucault se encuentra en los dos textos: un marcado juego que hace permanente referencia al honor y a la vergüenza.

2. El muchacho griego: Siguiendo con el tema del honor se hace referencia al tema de muchachos de reputación dudosa que llegaban a las más elevadas funciones políticas. Hay un período de prueba, en el cual el joven es deseable, su honor, frágil. Se prueba su valor, se forma, se ejerce y se mide.

3. La prueba: Se necesita para saber sobre el honor del muchacho, para evitar descuidarse en el cuidado del cuerpo evitar la rhathymia: la molicie, las miradas por el pudor aidös, la forma de hablar como silencios, temas graves y ligeros y sobre la calidad de la gente que se frecuenta (Foucault, 2007). De tal manera que la reflexión moral se dirige más a caracterizar el tipo de actitud y de relación con uno mismo que se requiere entre los muchachos.

4. Las formas gestuales: Synêtheia significa tanto, vida común, como relación sexual. No es necesario que el muchacho se conduzca pasivamente, que se deje dominar, que ceda sin combatir, que se haga complaciente compañero de los placeres de otro, de sus caprichos y demandas por molicie, por gusto del deleite o por interés. Existe un principio de honor que se evidencia en comportamientos del muchacho como es no aceptar al primero que pase, conceder sus favores al que ofrece más.

5. La reflexión filosófica: En la dietética el tema de reflexión es el dominio sobre sí y sobre la violencia de un acto peligroso. En la económica: El poder que se ejerce sobre uno mismo, en la práctica del poder se ejerce sobre la mujer. En la erótica el saber asegura el dominio sobre el muchacho. El muchacho: En la moral y el pensamiento griego era un elemento difícil y delicado. Su vida (bios), es una obra común, una obra que se perfecciona con el 
esplendor que le dan todos. Luego en la cultura europea es la joven y la mujer el tema de preocupación privilegiado. Lo peculiar del placer con el muchacho entre los griegos radica en que se aceptaba dicho placer con dificultad y que esa complejidad dio lugar a una elaboración cultural.

\section{El objeto del placer}

El comportamiento social y las relaciones sexuales conllevan según Foucault la misma forma puesto que en el comportamiento sexual hay un papel intrínsecamente honorable.

Cita Foucault a Aristóteles en la cuestión del gobierno de manera que el gobernar esclavos no es gobernar seres libres, gobernar a una mujer es ejercer un poder político en relaciones de permanente desigualdad, y el gobierno de los niños es real porque descansa en el afecto y la superioridad de la edad. Lo que no pasa con el someter al muchacho pues no es un objeto prohibido, existen leyes en Atenas que protegen a los niños libres, aunque cualquier adolescente es compañero sexual de un hombre, se prohíbe la prostitución masculina como un caso de deshonra pública. Para Foucault (2007): "en el juego de las relaciones de placer, cuando se desempeña el papel del dominado, no se podría ocupar válidamente el lugar del dominante en el juego de la actividad cívica y política” (p. 202).

De esta manera se reconoce al joven como objeto de placer, pues nadie puede censurar al que disfrute de un muchacho porque lo ama, siempre que respete las leyes y convenciones. Pero el muchacho no puede aceptarse en esta relación siempre pensada como dominación, no puede ni debe identificarse con su papel, pues para Foucault (2007): “...si se admite con toda evidencia como natural experimentar placer con un muchacho, es mucho más difícil aceptar como natural lo que hace de un muchacho el objeto de placer" (p.204). Luego cita a Platón en cuanto a la aceptación del amor a los muchachos, pero expone que en sus obras últimas se "corrige" al punto de condenarlo "contra natura". Concebir al muchacho como objeto de placer, dio lugar a emplear expresiones generales: "hacer la cosa", evitando nombrar la situación, recurriendo a metáforas: "ceder", "someterse", "ponerse a las órdenes". Según Sócrates, entre el hombre y el muchacho no puede haber comunidad de placer. Jenofonte refiere que a quienes más se condena, por sus maneras, maquillajes, adornos, perfumes, es a los muchachos que encuentran placer en desempeñar el papel. 
Charizesthai significa el hecho de aceptar y conceder, por parte del muchacho, sus favores, de manera que hay algo más que una rendición, se ha aceptado sin precipitación ni mala gana, dar placer a otro, poniendo condiciones y estableciendo el beneficio que se puede obtener, de manera que para Foucault:

... el muchacho ha de dar por complacencia y por algo más que por su propio placer algo que su compañero busca por el placer que va a proporcionarle: pero éste no puede pedírselo legítimamente sin la contrapartida de regalos, beneficios, promesas y compromisos que son de muy distinto orden que el "don" que se hace" (Foucault, Michel, 2007p. 207).

Consolidando así la transformación del amor en un vínculo definitivo y socialmente preciado, la philia.

En el capítulo cinco Foucault trabaja el tema del verdadero amor, para este tema también inicia con la reflexión sobre los muchachos y la forma como estos llegan a complacer a quienes los cortejan, es decir se hace la reflexión sobre porque los muchachos acceden a lo que su amante les propone y en qué casos es necesario y conveniente que los muchachos no accedan. Entonces desde el tema del consentimiento se plantean las primeras explicaciones sobre el amor verdadero, la primera de ellas es la ofrecida por Aristófanes en el Banquete, a quien cita Foucault (2007): “al explicar la partición de los seres primitivos por la cólera de los dioses y su separación en dos mitades (machos y hembras, o ambas del mismo sexo, según que el individuo originario fuera andrógino o por entero masculino o femenino)" (p.212), de manera que el amor se basa en la búsqueda de la mitad perdida en el origen, con lo cual se explica porque los muchachos acceden unos con más facilidad que otros, ya que buscan su mitad hombre y en su adultez lo seguirán haciendo al buscar a los muchachos.

La siguiente visión tratada por el autor es la explicación del amor dada por la Erótica socrático-platónica que inicia su reflexión sobre la pregunta: ¿Qué es el amor en su ser mismo?, para lo cual se hace la diferencia entre el amor del cuerpo y el amor del alma, de este sale el amor verdadero y se transforma en amistad, "philia" es el principio que da valor a toda relación.

En la erótica platónica se parte de la pregunta sobre el lugar que deben ocupar las aphrodisia en las relaciones amorosas, pero nuevamente se parte del consentimiento de los 
muchachos frente a quienes los aman y los que no, pues quien ama no se encuentra verdaderamente consiente, mientras el que no lo hace se mantiene en la realidad.

Es evidente que el comportamiento sexual en los griegos era entendido desde lo masculino desde el dominio de sí mismo, pues el sujeto es quien constituye su propia conducta moral desde la Dietética que determina el uso medido y oportuno de las aphrodisia; la Económica como una forma de templanza que garantiza el dominio sobre la mujer y la administración efectiva de sus bienes y el poder; la Erótica desde con quien se deben compartir las conductas sexuales que llevan al hombre a dominarse de tal manera que sea sujeto de conducta moral para sí mismo.

\subsection{La sexualidad en el marco del cristianismo}

La raíz para entender el papel de la sexualidad en el cristianismo primitivo es la concepción dualista del ser humano, que no tiene su origen ni en la tradición judía, de la que arranca el cristianismo, ni en Jesús de Nazaret, con quien se inicia el itinerario de la fe cristiana. Platón está en el origen de esta concepción antropológica, Pablo de Tarso le da un tono moralista y Agustín de Hipona ofrece una fundamentación teológica de la misma dando como resultado la teoría y práctica oficiales en el cristianismo.

La concepción antropológica dualista distingue en el ser humano dos elementos que se oponen frontalmente: el cuerpo o la parte material y el alma o la parte espiritual. Lo que identifica al ser humano es el alma, que constituye la esencia de la persona. El cuerpo no sólo no forma parte de la estructura esencial del ser humano, sino que es lastre, peso, carga; más aún, es la cárcel donde vive presa el alma durante su peregrinación por la tierra y de la que tiene que liberarse, lo cual expresa claramente Platón en el Fedón: "Mientras tengamos el cuerpo y esté nuestra alma mezclada con semejante mal, jamás alcanzaremos de manera suficiente lo que deseamos", "Preciso es considerar que el cuerpo es pesado, torpe, terrestre y visible. Y que, poseyéndolo, el alma es entorpecida, retenida y atraída de nuevo por la esfera de lo visible" (p.10). El cuerpo y todo lo que tiene que ver con él, es la causa de lucha, contienda y conflicto,

\footnotetext{
${ }^{5}$ Platón: Fedón o Acerca del alma. Recuperado de: www.philosophia.cl / Escuela de Filosofía Universidad ARCIS. Consultado: 11-abril-2013. (p.10)
} 
con lo cual no puede dedicarse a reflexionar y difícilmente se dedica a la filosofía, así mientras el cuerpo este presente no es posible contemplar la verdad ni conocer nada de forma pura.

Por esta razón es necesario castigar el cuerpo, reprimir sus instintos, renunciar a todo lo que pueda ser considerado placer corporal, para así llegar a la plena liberación que finalmente llegaría con la muerte y dejaría el alma en plena libertad

Mientras estemos en vida, más cerca estaremos de conocer, según parece, si en todo lo posible no tenemos ningún trato ni comercio con el cuerpo, salvo en lo que sea de toda necesidad, ni nos contaminamos de su naturaleza, manteniéndonos puros de su contacto, hasta que la divinidad nos libre de él" (Platón, p.10).

Pablo de Tarso defiende una antropología unitaria en sintonía con el pensamiento hebreo en el que fue educado. Sin embargo en sus cartas, aparecen ciertos rasgos de dualismo antropológico, como demuestran las exhortaciones morales que hace a los cristianos y cristianas de las comunidades fundadas o animadas por él. Buena parte de las listas de pecados que aparecen en dichas cartas tienen que ver con la sexualidad, y las actitudes morales que recomienda a los creyentes en Cristo son claramente represivas del cuerpo. Carne y espíritu aparecen como dos principios que caminan en dirección contraria. Escribe a los cristianos de Galacia:

Proceded según el Espíritu, y no deis satisfacción a las apetencias de la carne. Pues la carne tiene apetencias contrarias al espíritu, y el espíritu contrarias a la carne, como que son entre sí tan opuestos que no hacéis lo que queréis... Las obras de la carne son conocidas: fornicación, impureza, libertinaje, idolatría, hechicería, odios, discordias... Los que son de Cristo han crucificado la carne con sus pasiones y sus apetencias” (Gálatas 5,16 ss).

San Pablo compara la unión matrimonial con la unión de Cristo con su Iglesia, por lo tanto condena toda relación sexual fuera del matrimonio: "el hombre en cuanto cuerpo pertenece ya aquí a la esfera del Espíritu, por lo que nuestro cuerpo carnal es ya espiritual (1 Cor 6,17), en espera del gran día de la resurrección" (1 Cor 6,14). De tal manera que todas las relaciones sexuales fuera del matrimonio son claramente condenadas: “¿No sabéis acaso que los injustos no heredarán el Reino de Dios? ¡No os engañéis!...Ni los impuros, ni los idólatras, ni los adúlteros, ni los afeminados, ni los homosexuales" (1Cor 6,9); "Porque tened entendido que ningún fornicario o codicioso - que es ser idólatra- participará en la herencia del Reino de Cristo y de 
Dios" (Ef 5,3-5); "Por eso, mientras vive el marido, será llamada adultera si se une a otro hombre" (Rom 7,3); "Sólo se oye hablar de inmoralidad entre vosotros y una inmoralidad tal, que no se da ni entre los gentiles, hasta el punto de que uno de vosotros vive con la mujer de su padre" (1Cor 5,1); "Porque esta es la voluntad de Dios: vuestra santificación; que os alejéis de la fornicación” (1 Tes 4,3); “¡Huid de la fornicación! Todo pecado que comete el hombre queda fuera de su cuerpo; mas el que fornica, peca contra su propio cuerpo" (1Cor 6,18). Así Pablo condena la impureza como una falta grave, siendo muy severa su condena de las relaciones homosexuales, el incesto, el adulterio, la prostitución; llegando incluso a asociar desorden sexual e idolatría, con la consecuente pérdida de la herencia del Reino de Dios; así mismo toda forma de fornicación es una falta contra el amor que niega el sentido de la sexualidad y ofende a la dignidad humana.

Del mismo modo las cartas paulinas enumeran a menudo la castidad entre los principales signos de conversión a Cristo, y la exige al hombre cristiano que vive según el espíritu de Cristo: “en pureza, ciencia, paciencia, bondad, en el Espíritu Santo, en caridad sincera” (2 Cor 6,6); "Procura, ser para los creyentes modelo en la palabra, en el comportamiento, en la caridad, en la fe, en la pureza" (1 Tim 4,12); del mismo modo a las mujeres también las invita a vivir la castidad desde el matrimonio y la fidelidad a sus maridos: "a ser sensatas, castas, hacendosas, bondadosas, sumisas a sus maridos, para que no sea injuriada la Palabra de Dios” (Tit 2,5).

Para el cristianismo primitivo es muy importante teniendo en cuenta la sexta bienaventuranza "Bienaventurados los limpios de corazón porque ellos verán a Dios" (Mt 5,8), mantener la pureza interior, que procede del corazón, pues no basta con no cometer adulterio, sino que es preciso conservar limpia la mirada. La pureza del corazón es el preámbulo de la visión de fe, mientras que la corrupción sexual hace que el hombre se vuelva ciego a las realidades espirituales, pues el mantener la pureza lleva al creyente a buscar hacer la voluntad de Dios con un compromiso íntegro e indiviso, de manera que ve al otro como prójimo, más no como objeto de deseo sexual y además considera el cuerpo humano, tanto el propio como el del otro como un templo del Espíritu Santo y una manifestación de la belleza divina. 
San Agustín luego de pasar por el neoplatonismo y leer las cartas de san Pablo, hizo suya la concepción antropológica dualista en su vida, al renunciar a los placeres del cuerpo, después de su conversión, por considerarlos un obstáculo para la salvación, como en su doctrina, proponiendo como ideal cristiano la abstinencia sexual. Es así que la actividad sexual para que no sea un impedimento para que el hombre llegue a la salvación, solamente se puede realizar al interior del matrimonio cristiano, tema sobre el cual el santo de Hipona dedica varios de sus escritos; en "la bondad del matrimonio", Agustín sienta las bases del matrimonio cristiano en la sociedad:

La primera alianza natural de la sociedad humana nos la dan, pues, el hombre y la mujer conyugados. A los cuales no los creó Dios por separado, uniéndolos luego como si fueran extraños, sino que creó a una del otro, significando así la virtud unitiva en el costado, de donde la mujer fue extraída y formada. ${ }^{6}$

Sin embargo esta alianza según San Agustín también necesita de la unión sexual que tendrá como resultado los hijos, como uno de los tres bienes del matrimonio cristiano, es recurrente en varios textos sobre el matrimonio que esta institución ha sido creada por Dios para la procreación y educación de la prole.

Así, en su comentario al Génesis, al interpretar Gn., 2,18 dirá: "Cuando se pregunta para qué clase de ayuda del varón es hecho aquel sexo (la mujer), a mi parecer solamente a causa de la prole, para que a través de ella la tierra se llene" ${ }^{7}$, así entonces para san Agustín la mujer debe contraer matrimonio solo para la función de ser madre. En Contra Faustum, San Agustín expresa:

Por eso, la ley eterna, es decir la voluntad de Dios creador de todas las criaturas, tomando consejo para la conservación del orden natural, no para servir el deseo, sino para cuidar la preservación de la raza, permite que el placer de la carne mortal sea liberado de la razón en la cópula, solamente para propagar la especie. ${ }^{8}$

\footnotetext{
${ }^{6}$ Agustín, la bondad del matrimonio. Recuperado de: www.augustinus.it/ Consultado: 11-abril-2013

${ }^{7}$ Agustín, Comentario al génesis. Recuperado de: www.augustinus.it/ Consultado: 11-abril-2013

${ }^{8}$ Agustín, Contra Faustum. Recuperado de: www.augustinus.it/ Consultado: 11-abril-2013
} 
Se puede decir que toma san Agustín un argumento totalmente estoico donde se manifiesta una profunda desconfianza frente al placer en general y al sexual en particular, ya que para la moral estoica es prohibido hacer algo por placer, solo el acto sexual originado en una intención procreativa es honesto y bueno. De lo contrario y si es ejercido en el matrimonio, es como un adulterio leve, pues no se traspasan los límites de la fidelidad conyugal. En este aspecto, Agustín considera que hay dos clases de bienes al interior del matrimonio: aquellos que son dignos de ser buscados por sí mismos como serían, la sabiduría y la amistad; y otros que son medios de acuerdo a la finalidad para la cual han sido creados, como es el caso del comer, el beber y las relaciones sexuales, entonces actúan de manera correcta ante este último tipo de bienes, aquellos que los usan para alcanzar la finalidad natural que tienen, en el caso de la relación sexual es la procreación y sólo así se obra conforme a la naturaleza.

San Agustín destaca la amistad espiritual, o relación interpersonal de amor entre esposo y esposa, que tiene su valor propio, de tal modo que en este plano y permaneciendo en "amistad" los esposos no están obligados a buscar la procreación y esta basta para asegurar el valor del matrimonio, este es el caso de las personas ancianas o de los que han optado por renunciar a la intimidad sexual conyugal, como María y José permaneciendo en unión de amistad. Es claro que esta unión espiritual, para Agustín, será más fuerte en la medida que los esposos se aparten de lo que llama "atracción de la carne", como expresión de la continencia absoluta. Esta opción se puede comparar con el vínculo indisoluble de Cristo y la Iglesia, basándose en la caridad y la fidelidad.

Otro tema que vale la pena desarrollar en la visión dualista de San Agustín, es el cuerpo, considerado en la historia del cristianismo elemento clave para la salvación y así mismo para la condenación. En este tema se evidencia la concepción dualista pues si no se controlan las pasiones, se pone en juego la vida eterna. Por esta razón muchos de los santos antiguos decidían alejarse del mundo con el fin de dominar el cuerpo y menospreciarlo al no cuidarlo. Para la tradición cristiana la mejor forma de frenar las pasiones y de proteger el cuerpo y el alma de los cristianos, sobre todo, de las mujeres cristianas, es renunciar al ejercicio de la sexualidad, vivir en estado de virginidad, como lo hicieron José y María en el inicio del cristianismo, así la salvación 
depende en buena medida de la castidad que se haya observado y la vivencia de esta en la intimidad del matrimonio.

Con respecto al cuerpo de la mujer, la tradición cristiana lo ve como motivo de tentación, causa de pecado y caída para al hombre. Por tanto el cuerpo de la mujer por considerarse un elemento que lleva a la sensualidad, debe ocultarse, en lo posible no enseñarse, castigar para ser dominado y por tanto no cuidarlo, no exhibirlo y mucho menos embellecerlo, pues es ocasión de obstáculo para llegar a la vida eterna, así mismo no es portador de gracia, sino de pecado y en el único caso que el cuerpo de la mujer sirve al hombre es para la procreación y la asistencia de los hijos.

\subsection{La sexualidad en el nuevo mundo}

Las culturas prehispánicas transmitieron una visión cosmogónica a la inferioridad de la mujer, equiparándola con la tierra, frente al cielo, que era masculino, o con la luna, frente al sol vencedor y masculino. Así, en la cosmogonía prehispánica se han proyectado numerosas representaciones femeninas, una de ellas es Pachamama: la madre Tierra para los pueblos habitantes de la región andina. Chicómecoatl, en náhuatl es la diosa de la subsistencia del maíz, principal patrona de la vegetación y de la fertilidad. Coatlicue es una divinidad azteca asociada con la madre de Huitzilipochtli, por eso recibía el nombre de madre de los dioses, representada como una mujer usando una falda de serpientes y Tlazolteotl, en la cultura náhuatl, relacionada, con la tierra y con el nacimiento, además de ser la diosa más relacionada con la sexualidad, además de tener la misión de sacar del mundo todo el sufrimiento y lo negativo.

Para la investigadora Carola Reyes en las sociedades Mesoamericanas "el hombre era responsable del bienestar de su familia" ${ }^{9}$, pues era el encargado de proveer todo lo necesario para que su familia estuviera bien y además se responsabilizaba de pagar los impuestos para el gobierno. Mientras que según Reyes: "las tareas de la mujer también requerían de mucha energía" (p.8) ya que la mujer se encargaba de todas las tareas domésticas entre ellas el hilado y el tejido además del cuidado de los niños. Mientras que en las sociedades de los Andes las tareas

\footnotetext{
${ }^{9}$ Reyes C. (2005). Culturas precolombinas. Unitec Auckland. Consejería de educación en Australia y Nueva Zelanda. Consultado: 25-abril-2013. p.8
} 
de las mujeres se determinaban según su posición social, de manera que las mujeres pertenecientes a clases modestas debían ayudar a sus maridos en las tareas agrícolas y también responder por las obligaciones domésticas y el cuidado de los hijos. Desde la más tierna infancia los niños debían ayudar a sus padres en las tareas y actividades de acuerdo a su sexo, los varones ayudaban a sus padres en tareas como el cultivo de la tierra, caza, pesca, etc. y las mujeres ayudaban a sus madres en tareas como hilado, tejido y demás labores domésticas.

Con respecto a la crianza de los hijos en la cultura Inca, Reyes refiere: "tanto ricos como pobres sin distinción eran bastante severos con lo respecta a la crianza de los niños” (p.9), de manera que los niños recibían pocas muestras de cariño y en cambio su educación se encaminaba a aprender lo necesario para dedicarse al trabajo arduo que les correspondía realizar.

Para la cultura Náhuatl es importante la educación que los padres les den a sus hijos y los consejos que esto les den para su vida adulta. Muestra de esto es la poesía náhuatl: “Consejos de un padre a su hija", en las palabras del padre se van transmitiendo todos los ideales de los antiguos mexicanos, presentados hermosa y tiernamente en forma entendible para su hija, además de las recomendaciones de valores morales y sexualidad propios del comportamiento de la mujer. Así se puede analizar que los Aztecas daban una gran importancia a la pureza a través de los consejos que los padres transmitían a sus hijos respecto a la moral sexual y la pureza:

No como si fuera un mercado busques al que será tu compañero, no lo llames, no como en primavera lo estés ve y ve, no andes con apetito de él. Pero, si tal vez tú desdeñas al que puede ser tu compañero, el escogido del Señor nuestro, si lo desechas, no vaya a ser que de ti se burle, en verdad se burle de ti y te conviertas en mujer pública ${ }^{10}$

Otro consejo que daba el padre a su hija y que se refiere directamente a la moral sexual y la integridad del cuerpo de la niña: "Pero, prepárate, ve bien quién es tu enemigo, que nadie se burle de ti, no te entregues al vagabundo, al que te busca para darse placer, al muchacho perverso", también se puede ver la importancia que dan los Aztecas a la unión con la pareja:

Que tampoco te conozcan dos o tres rostros que tú hayas visto. Quien quiera que sea tu compañero, vosotros, juntos, tendréis que acabar la vida. No lo dejes, agárrate de él, cuélgate de él aunque sea un pobre hombre, aunque sea sólo una aguilita, un tigrito; un infeliz soldado, un pobre noble, tal vez cansado, falto de bienes, no por eso lo desprecies.

\footnotetext{
${ }^{10}$ www.ecovisiones.cl/tradiciones/articulos/cartanahuatl.htm. Consultado: 25-abril-13
} 
Otra característica de la unión con la pareja es la disposición de esta para toda la vida, la tradición y los antepasados:

Sé cuidadosa, porque vienes de gente principal, desciendes de ella, gracias a personas ilustres has nacido. Tú eres la espina y el brote de nuestros señores. Nos fueron dejando los señores, los que gobiernan; los avales allá se fueron colocando en fila, los que vinieron a hacerse cargo del mundo en el mundo; dieron renombre y fama a la nobleza.

Escucha: mucho te he dado a entender que eres noble. Mira que eres cosa preciosa, aun cuando seas tan sólo una mujercita. Eres piedra fina, eres turquesa. Fuiste forjada, taladrada, tienes la sangre, el color, eres brote y espina, cabellera, desprendimiento, eres de noble linaje.

En las enseñanzas del padre a su hija también se pueden encontrar las indicaciones que tienen que ver con el honor:

Que nunca sea vano el corazón de alguien, nadie diga de ti, te señale con el dedo, hable de ti. Si nada sale bien, ¿cómo será tu fracaso? Por eso, ¿no vendremos nosotros a ser vituperados? Y si ya nos recogió el Señor nuestro, ¿acaso por esto no se nos vituperará por atrás, acaso no seremos reprendidos en la región de los muertos? En cuanto a ti, ¿acaso no pondrás en movimiento en tu contra el palo y la piedra? ¿No harás que contra ti se dirijan?

Pero si atiendes, ¿también entonces podrá venir la reprensión? Tampoco seas ensalzada por otros en exceso, no ensanches tu rostro, no te ensoberbezcas, como si estuvieras en el estrado de las águilas y los tigres, como si estuvieras luciendo tu escudo, como si todo el escudo de Huitzilopochtli estuviera en tus manos. Como si gracias a ti estuviera levantando la cabeza, y a nosotros nos acrecentaras el rostro. Pero si no haces nada, ¿no serás entonces como una pared de piedra, no se hablará de ti, apenas serás ensalzada? Pero sé en estas cosas como lo desea para ti el Señor nuestro.

He aquí otra cosa que quiero inculcarte, que quiero comunicarte, mi hechura humana, mi hijita: sabe bien, no hagas quedar burlados a nuestros señores por quienes naciste. No les eches polvo y basura, no rocíes inmundicias sobre su historia, su tinta negra y roja, su fama.

No los afrentes con algo, no como quiera desees las cosas de la tierra, no como quiera pretendas gustarlas, aquello que se llama las cosas sexuales y si no te apartas de ellas, ¿acaso serás divina? Mejor fuera que perecieras pronto.

También se puede encontrar enseñanza sobre la misión de la mujer en la familia y las labores del hogar: 
He aquí tu oficio, lo que tendrás que hacer durante la noche y durante el día, conságrate a las cosas de Dios, muchas veces piensa en el que es como la Noche y el Viento. Hazle súplicas, invócalo, llámalo, ruégale mucho cuando estés en el lugar donde duermes. Así se te hará gustoso el sueño. Y hecho esto, cuando ya estés lista, ¿qué harás? ¿Cómo cumplirás tus deberes femeninos? ¿Acaso no prepararás la bebida, la molienda? ¿No tomarás el huso, la cuchilla del telar? Mira bien cómo quedan la bebida y la comida, cómo se hacen, cómo quedan buenas, cómo se hacen una buena comida y una buena bebida.

Estas cosas que de algún modo se llaman "las que pertenecen a las personas" son las que corresponden a las señoras, a los que gobiernan, por esto se las llamó "cosas propias de las personas", la comida propia de los que gobiernan, su bebida: sé diestra en preparar la bebida, en preparar la comida.

Pon atención, dedícate, aplícate, aplícate a ver cómo se hace esto, así pasarás tu vida, así estarás en paz. Así serás valiosa. No sea que en vano alguna vez te envíe el infortunio el Señor nuestro. Acaso crezca la pobreza entre los nobles. Míralo bien, abrázalo, que es oficio de mujer: el huso, la cuchilla de telar.

En el nuevo mundo en el marco de la conquista y la evangelización se hace evidente un riguroso control religioso y social al comportamiento sexual de las personas y de las parejas, así como de la reproducción y la formación de los hogares. Plantea Asunción Lavrin en el texto Sexualidad y matrimonio en la América hispánica Siglos XVI-XVIII, que "el estado y la iglesia también han visto en la institución familiar un medio de socialización de la moral y la política"(p.10), lo cual explica porque tanto interés de estas dos instituciones en regir el comportamiento en pareja para las personas, ya que constituye este una forma de dominio y garantía de orden social, ya que la simple elección de la pareja como una elección personal se convierte en una elección que atañe al núcleo social, convirtiéndose esta simple elección en un compromiso de familias y otros grupos sociales, donde además entra en juego la herencia y el patrimonio familiar.

Para garantizar este último es donde aparece el Matrimonio como el mecanismo que garantiza social y económicamente la unión de intereses familiares, o de un determinado grupo, más que ser este la respuesta emocional de una persona a su deseo de vivir en pareja, lo cual expresa Lavrin (1991): “En la América Latina colonial el matrimonio no era ni el resultado 
exclusivo del noviazgo ni el único canal de expresión sexual” (p.14), entonces se puede formular la pregunta: ¿es el matrimonio solamente una institución que garantiza el orden social durante la colonia?, ya que avanzando en el texto se encuentra que las cuestiones relativas a las prácticas sexuales de las personas como son homosexualidad, bigamia y poligamia, relaciones clandestinas entre clérigos y seglares, etc., son prácticas bastante frecuentes en los siglos XVI y siguientes. Plantea Lavrin que las relaciones personales y domesticas son el punto de partida para entender el papel de la iglesia y el estado como mecanismos de control, que la reglamentación convenida entre las dos instituciones llevo a mantener un orden social basándose en el equilibrio de la influencia que estas podían ejercer en la sociedad. (Lavrin, 1991)

Así el Estado se concentraba más en aspectos legales con relación al comportamiento sexual y el matrimonio, con respecto a este era interés del estado dar legalidad a la unión marital para garantizar la herencia y la división de los bienes entre padres e hijos. Mientras que la Iglesia se interesó en enmarcar la unión marital de forma sacramental para darle vínculo con lo espiritual, es decir dar a la sexualidad un carácter teológico, en palabras de Lavrin (1991) "la salvación del alma” (p.15), así la Iglesia tenía más influencia en la vida privada de las personas y su comportamiento sexual.

Esta necesidad de control fue motivada porque la Iglesia y los conquistadores llegan al nuevo mundo y se encuentran con unas costumbres de moralidad sexual prescritas en las culturas, en algunas más rigurosas que en otras, y con el uso de la violencia las prácticas sexuales tanto de los conquistadores como de los conquistados no tuvieron mayores pautas morales y se dieron de forma libre uniones entre españoles e indígenas o negras. Es entonces a partir de 1530 cuando se siente la necesidad de ejercer un control sobre las prácticas sexuales e imponer reglamentación de acuerdo al modelo español y el comportamiento cristiano; para Lavrin (1991): "Su objetivo consistía en estimular la formación de familias según modelos ibéricos y aplicar sus procedimientos legales" (p.16), bajo este modelo la familia se revirtió en el núcleo social básico y el matrimonio su punto de partida. Este no era muy aceptado por los indígenas sobre todo por los grupos con costumbres poligámicas, lo cual se constituye en motivo de gran preocupación y esfuerzo para los teólogos que buscan convencer a esta población del sentido del matrimonio. 
En el nuevo mundo estaba cambiando la población y en el siglo XVII la mayoría de esta era mestiza, lo cual representa para la iglesia el nuevo reto de controlar el crecimiento de esta "población heterogénea", lo cual fue interés de la Iglesia bajo la visión del concilio de Trento (1542-1563) con la reglamentación establecida por este para los casamientos y para el comportamiento sexual en el Nuevo Mundo, un ejemplo de norma sobre este comportamiento, cita Lavrin (1991), lo que respecta a la palabra de matrimonio: "las promesas verbales eran revocables, siempre y cuando no hubiera habido relación sexual. El carácter central de la unión física era de suma importancia” (p.18), con el concilio de Trento se reglamentó el rito del matrimonio dando importancia a la palabra a futuro de la pareja lo cual implicaba un compromiso de las partes, además del carácter público que le da Trento, para evitar encubrimientos y escapar al control de la Iglesia en la relación de la pareja, mientras que el estado mediante el derecho civil mantiene control sobre la herencia y la propiedad en la familia como unidad social básica.

Estas leyes sobre el matrimonio se reglamentaron a fines del siglo XVI, mediante los concilios provinciales de Lima en 1582 y Nueva España en 1585, mientras que en Brasil se había reglamentado desde 1707. Ritualmente estas leyes se veían reforzadas mediante el sermón y la confesión, medios que los sacerdotes utilizaban para dar a sus feligreses normas de conducta, entre ellas las relaciones entre hombres y mujeres y cuyo incumplimiento se creía que llevaba a la condenación del alma, así la Iglesia se aseguró de mantener mecanismos de control de índole personal y social valiéndose de su influencia en el plano espiritual.

Es de resaltar la confesión como uno de estos elementos de control utilizados por la Iglesia al explorar por medio de ella el alma y las debilidades humanas, así como la incidencia de la sexualidad en la vida de los indígenas y la población de la época, es también la confesión el medio que posibilita a la iglesia un completo conocimiento de la forma de pensar y de actuar de la población en su comportamiento sexual, dándole la viabilidad de construir todo un conjunto de normas que no daban posibilidad de una mala conducta sexual. Estas normas van formando a las nuevas generaciones que creen en su validez y a ellos también se les formó en la idea que el incumplimiento de esas normas se entiende como pecado, pero la población aún al entenderlo así no dejaba de cometerlo, auto encubrirlo y luego confesarlo aprovechando la obligación de la iglesia de perdonar los pecados. 
Se plantea además que en el contexto del mundo indígena la confesión se utilizó como la forma para hacer llegar los ritos y el mensaje de conversión a los nahuas en la nueva España, lo que Lavrin (1991) expresa: "La confesión es una técnica psicológica de persuasión, una sutil forma de subvertir valores culturales, de conseguir la aceptación y lograr la aculturación” (p.22), convirtiéndose la confesión en la forma para que los sacerdotes terminaran convenciendo a los indígenas de las enseñanzas cristianas y haciéndolos olvidar las propias. Especialmente este proceso se dio para sustituir los valores de comunidad de los grupos indígenas por una experiencia de individuo que diera más una costumbre de religión personal.

Otro aspecto importante es el concepto del honor como un complejo conjunto de normas de conducta que regían el comportamiento personal y social, los actos de los individuos llegan a afectar de manera positiva o negativa la sociedad y esto mismo lo lleva a ser considerado como un sujeto honorable, lo cual era importante en una sociedad distinguida y estratificada por factores étnicos, culturales y económicos. El comportamiento sexual es el elemento que más afecta el honor, por ser una conducta con múltiples consecuencias sociales, además de ser el foco de cantidad de reglas impuestas por la iglesia para garantizar la familia desde la autoridad patriarcal y como mecanismo de control de los padres hacia los hijos y es este mismo orden el que impone bastantes restricciones a la mujer para cuidar su honor tanto personal como familiar y así garantizar la legitimidad de los hijos como medio de mantener la posición socioeconómica.

Es parte del concepto del honor para la mujer la conservación de la virginidad, teniendo esta un significado físico y moral en la tradición cristiana llevando consigo connotaciones sociales. Se entiende desde el orden físico porque garantiza la castidad y la pureza de la novia al llegar al matrimonio libre de toda mancha, lo que también avala que la familia sea honorable; en la colonia la virginidad es un parámetro de superioridad moral y por lo tanto social, tanto que la doncella es distinta a la mujer soltera, ya que la primera es virgen y la segunda no y eso determina dos posiciones sociales bien distintas; esto es evidente en la sociedad colonial donde son frecuentes las relaciones sexuales fáciles con mujeres de clase socio-étnica baja, lo cual establece diferencia con las mujeres de posiciones sociales más altas. 
Pero la virginidad no es lo único importante en el concepto del honor ya que en el matrimonio tanto mujeres y hombres debían mantener unas conductas propias de su condición, siendo las de la mujer la fidelidad y el recogimiento las virtudes que garantizan el honor de una esposa y el de su familia, además de las buenas cualidades propias de las mujeres mencionadas por Fray Martín de Córdoba en "Jardín de nobles doncellas" citado por Lavrin (1985): "entre las buenas cualidades de las mujeres mencionaba la vergüenza, la piedad, el respeto" y entre las "malas cualidades se encuentran: intemperancia, locuacidad, obstinación y la inconstancia" (p.36), pues estas malas actitudes constituían una clara tentación con respecto a la sexualidad femenina y un claro atentado contra la castidad y la virginidad, considerados como los mayores triunfos de una mujer.

A todas luces el matrimonio es el mecanismo del que se valen tanto la iglesia como el estado para mantener el orden social y económico de la sociedad colonial, además de ser el medio por el cual se conservó el status social de la familia y se mantuvo la pureza racial. Además de legitimar el comportamiento sexual tanto de hombres como de mujeres; para los hombres hay cuatro normas que definen su responsabilidad y alcance en el matrimonio:

1. Dar el apoyo material necesario a la familia

2. Respetar a la esposa y su persona

3. Mantener una conducta adecuada en las relaciones sexuales

4. Mantenerse fiel a su esposa.

La Iglesia así como daba normas estrictas de comportamiento moral, también debió dar normas para cubrir consecuencias a las trasgresiones a la norma, como son: los hijos ilegítimos, los huérfanos, los divorcios, los casos de maltrato de uno de los miembros de la pareja al interior del matrimonio.

\subsubsection{La condición de la mujer en la Colonia}

Investigar la historia de la mujer en América Latina durante los siglos XVI a XVIII supone según la historiadora Asunción Lavrin encontrarse con la dificultad de intentar conocer íntimamente los pensamientos de las mujeres debido a los pocos escritos tales como diarios y cartas (Lavrin, 1985) que puedan mostrar la forma como las mujeres se veían a sí mismas y como 
ellas de primera mano cuentan su vida y sus costumbres, pero hay pocos escritos producidos por las mujeres y más bien lo que se conoce de la forma de vida de la mujer es lo que escriben los hombres sobre ellas o los manuales que escriben algunos hombres, sobre todo clérigos, para las mujeres. Esto se debe a que la gran mayoría de las mujeres apenas sabía leer, esto con respecto a las mujeres blancas, no las indígenas y las negras; y las monjas que se pueden considerar como las mujeres ilustradas de la época tienen escritos, pero estos no hablan sobre su vida secular, de manera que no dan gran detalle. De otra parte la mujer se encargaba del hogar con las tareas que este comprendía como cuidar de los hijos y del esposo, además de dedicarse a la oración y a las obras benéficas en el caso de las mujeres blancas y dedicarse al trabajo en el caso de las mujeres negras e indígenas, por lo tanto escribir no se encontraba dentro de las tareas asignadas a las mujeres en su diario vivir.

La mujer en Latinoamérica ha sido determinada por la etnia indígena de origen, por su procedencia étnica negra o blanca y sus respectivos mestizajes; en primer lugar las características de la mujer de etnia indígena, que se prolongan hasta nuestros días, son decisivas para entender el papel de la mujer en la historia latinoamericana, teniendo en cuenta que a la llegada de los conquistadores hay gran cantidad de mujeres indígenas y ellos por medio del sometimiento van interactuando con ellas de tal manera que las costumbres de las mujeres indígenas, su moral, su forma particular de subordinación al hombre y, sobre todo, su participación en el trabajo de la comunidad aborigen e inclusive de la descendencia, dan un sello peculiar al proceso de opresión. Así a pesar de la colonización española, la mujer indígena siguió conservando en algunas comunidades su estilo de vida comunitaria. Ante esto el español también usó estrategias para lograr consolidar lo que había conquistado por la fuerza, lo primero que hizo fue utilizar el matrimonio con mujeres indígenas influyentes para consolidar la hegemonía y dominación patriarcal, un ejemplo de esta situación lo muestra Lavrin (1985): "los españoles rápidamente se dieron cuenta de que por medio de su matrimonio con pallas incas, sus hijos alcanzarían una posición de mando en la sociedad indígena" (p.128), de manera que los conquistadores utilizaron no solamente la violencia, sino también la astucia para imponerse a las comunidades aborígenes e ir así determinando el estilo de vida de la sociedad colonial desde la familia patriarcal, llegando a que en algunos sitios los propios caciques aborígenes contribuyeron a consolidarlo aún con la 
resistencia de algunas mujeres indígenas que buscaban mantener el reconocimiento que habían logrado en sus clanes.

Es así que durante tres siglos se va consolidando y afianzando el patriarcado en la sociedad blanca y mestiza, al mismo tiempo que las comunidades aborígenes iban siendo llevadas a este mismo régimen, así mismo las comunidades negras también se van haciendo parte del régimen al depender de sus patrones. De esta manera toda la sociedad se ve implicada en este modelo patriarcal que va a ser un factor decisivo en el proceso de opresión de la mujer que poco a poco se va a aceptar y hacer costumbre que las funciones de la mujer, especialmente la de ama de casa, eran producto de una condición natural, llegándose a convertir en costumbre cultural. Para las mujeres indígenas acostumbradas en algunas comunidades a compartir labores agrícolas con sus parejas, esta costumbre de procurar para la mujer oficios meramente domésticos, es una cuestión extraña pues le sometía aún más, sobretodo en cuanto al tema económico, aunque no se puede desconocer que en algunas comunidades indígenas las mujeres fueron quienes activamente participaron en la manutención de la comunidad, debido a que se había menguado sustancialmente el número de hombres al interior de las comunidades y por otra parte porque los hombres debían producir para los terratenientes españoles.

En este sentido la fuerza de trabajo comenzó a separarse para hombres y mujeres, pues los hombres producían más en función de sostener una economía más abierta encaminada a la exportación, mientras las mujeres se concentraban en producir lo necesario al interior de la comunidad, de manera que el trabajo de las mujeres fue asimilado al trabajo doméstico, y el de los hombres al nuevo tipo de producción social para la exportación. Así mismo la principal labor de la mujer fue cumplir con su tarea de madre, procurando mantener la descendencia del conquistador, con respecto a este tema en un principio ante la ausencia de mujeres blancas en el nuevo mundo, el conquistador tomó la mujer indígena y en varios casos se dieron matrimonios con ellas, con lo cual las costumbres de las mujeres indígenas en cuanto a la producción y sostenimiento del grupo fueron cambiando para ir encerrándose en el hogar, espacio propio de la mujer y donde tendrá algo de autonomía e importancia en el caso de las mujeres blancas de alta posición social que se consideraba eran más importantes que los trabajadores al servicio de su esposo. 
Este espacio del hogar y el trabajo de las mujeres con respecto a los hombres es distinto para las mujeres de origen blanco, las indígenas, negras, mestizas y mulatas, las primeras, recluidas en el hogar, reproducían hijos para consolidar el sistema de dominación colonial y de clase y sufrían de esta manera el peso del patriarcado, mientras que las mujeres indígenas tenían que producir un excedente para pagar tributos además de la producción de lo necesario para vivir y el consumo comunal, como lo expresa Lavrin (1985): “. . las actividades de la mujer consistían en hilar y tejer para el uso de la casa familiar y para el tributo; la recolección y venta de granos y otros productos" (p.124), lo cual muestra que la mujer indígena tiene un papel importante en la producción y subsistencia de sus comunidades, ya que la mayoría de los hombres debían realizar forzosamente trabajos en las encomiendas de las minas y haciendas cumpliendo fuertes jornadas de trabajo y poniendo su vida en la explotación minera, esta situación de trabajo férreo ocasiono que las comunidades indígenas perdieran gran parte de sus miembros varones, por lo que la mujer se vio obligada a suplir esa fuerza de trabajo con su propio esfuerzo.

Adicional a esto la mujer indígena se puede decir que fue quien recibió en su cuerpo la violencia de la conquista, pues al ser violentada sexualmente recibía todo el peso del sometimiento del conquistador, lo cual expresa Asunción Lavrin (1985): "El violador dice implícitamente: "Yo soy tu amo; tú tienes que someterte a mí"”" (p.128), de manera que la mujer indígena se convierte en el símbolo de dominación de todo un pueblo y un territorio, pues la violencia ejercida sobre ella constituye claramente el propósito del conquistador de subyugar y oprimir, y así mismo los conquistadores se apropiaron de la capacidad reproductora de la mujer, perdiendo esta paulatinamente su capacidad erótica en esta función sexual-reproductora, separada del placer.

Esta forma de dominación desde la violación sexual se puede decir que es la base para que los hombres blancos impongan su dominio y que a lo largo del tiempo la subordinación sexual de la mujer al hombre se aceptara y se replicara en otros planos de la existencia, dando como resultado las familias patriarcales en la sociedad colonial y las familias tradicionales de América Latina. No obstante cuando pudo la mujer indígena utilizó a sus hijos mestizos para presionar al padre blanco, pues comprendió que por medio del establecer parentesco con los conquistadores también era posible que este tuviera ciertas consideraciones con ella, con su hijo y con su familia, como eran la exención de tributos y sobre todo para lograr una mayor movilidad social. 
Sin embargo, esta división de trabajos para el hombre y la mujer en algunas comunidades indígenas se mantuvo según sus propias costumbres antes de la llegada de los españoles, como es el caso de comunidades del sur de América, donde el trabajo en el campo siguió siendo para una economía tradicional de subsistencia y de tributos, ahora no para los señores Incas sino para los españoles y los pocos productos que quedaban como excedentes se comercializaban con grupos aledaños en esta región andina, según decía el cronista Cieza de León (1944): “las mujeres son las que labran los campos y benefician las tierras y mieses, y los "maridos hilan y tejen y se ocupan de hacer ropa"(p.272).

En centro América también se encuentran este tipo de costumbres como se ve en las investigaciones realizadas por la antropóloga Laurette Sejourné (1971), en la Nicaragua colonial, las mujeres indígenas se dedicaban al comercio, mientras los hombres se ocupaban de la agricultura y del hogar, como lo expresa la autora: "el mercado es el dominio de la mujer, quien no admite en él a hombres más que si son extranjeros. Los hombres del lugar no pueden pararse en él, ni siquiera por curiosidad" (p.131).

En cuanto a la situación de la mujer negra, es mucho más difícil encontrar escritos elaborados por mujeres negras y que describan su situación y sus vivencias en el nuevo mundo, pues desde su llegada la población negra se consideró como una mercancía y su función se determinó por su fuerza de trabajo, acompaña esta situación una fuerte ideología racista que fundamentó el comercio de esclavos a tierras americanas, considerándolos solamente "elementos" de trabajo. En el caso de las mujeres negras llegan ellas a trabajar en las tareas domésticas, al servicio de los patrones, en las casas señoriales del campo y la ciudad, lo cual explica la investigadora Rosa Soto Lira (1992) al referirse a la mujer negra: "en la hueste conquistadora, ella y la indígena "trabajaban" como sirvientas domésticas, encargadas de trasladar parte de los pertrechos, cocinar y lavar para su amo; los conquistadores además, las hacían servir como concubinas.” (pg.21), de manera que las mujeres negras son tratadas totalmente como objetos incluso para satisfacer sexualmente a sus dueños que aunque tenían como práctica constante utilizarlas sexualmente muy pocas veces aceptaron esta situación y desconocieron los hijos resultantes de estas uniones, de manera que estos niños se convertían también en parte del mercado de esclavos y con ellos se negociaba para pagar deudas o efectuar transacciones entre haciendas, de manera que la familia para los esclavos estaba totalmente sujeta 
a la propiedad del amo o a la voluntad de estos por darles su libertad. Es decir que la situación de la mujer negra se determinó por su fuerza de trabajo y la procreación de nuevos esclavos que constituían mano de obra para las plantaciones y las minas, así como los trabajos pesados del campo y la ciudad; en algunos sitios se dio la libertad a las esclavas, más no a sus vientres, de manera que sus hijos pertenecían a la mano de obra servil.

En cuanto a las mujeres blancas y mestizas, se puede decir que son quienes garantizan y continúan el predominio de las costumbres y el estilo de vida y cultura europea, en primera medida: la institucionalización de la familia monógama patriarcal, implantada en la Colonia, en el que las funciones de la mujer quedan reservadas al hogar en donde las tareas realizadas toman un carácter doméstico y servil, lo que propicia la calificación de ser secundario, débil o inferior por naturaleza, de manera que se comienza a valorar meramente por su función procreadora, mientras en los grupos indígenas la mujer se consideraba indispensable en el desarrollo del grupo y en las tareas agrícolas.

De esta manera se fue abriendo paso al interior de la sociedad colonial la ideología machista acerca de las virtudes naturales de la mujer: delicada, necesitada de protección, madre ejemplar, esposa sumisa cuya misión es cuidar y formar los hijos esmeradamente, ideología que aún hoy se encuentra presente en las sociedades mestizas latinoamericanas. Para Asunción Lavrin (1985): "El carácter patriarcal de las familias españolas y portuguesas se ha supuesto que sido el modus vivendi típico de todas las familias de la América Latina desde el siglo XVI hasta el XX”. (p.25)

De otra parte con la llegada de los españoles y portugueses se impuso por primera vez en América el tema de la Virginidad, como herencia de la tradición judeo-cristiana y elemento de dominación sexual, la virginidad para los grupos prehispánicos tenía un sentido totalmente distinto al presentado por los europeos, lo cual expresa Laurette Sejourné:

la causa, del repudio sería la falta de rectitud; la falta moral no era la pérdida de la virginidad, sino la mentira (...) Que las vírgenes no fueran buscadas por el hecho de serlo, que lejos de ser una condición para el casamiento constituyera la virginidad únicamente un factor físico como otro cualquiera, susceptible de atraer o de repeler, supone una libertad en la mujer tanto más verdadera, que, a la vez que se daba a la joven la facultad de prostituirse antes de la boda sin que eso fuera 
motivo de escándalo, existía el voto de virginidad fuera de toda implicación religiosa (...).

(Laurette Sejourné, 1971, p.128)

De tal manera que la virginidad en los grupos indígenas prehispánicos no tiene una connotación de pureza como lo tiene en el cristianismo, ni es condición necesaria de la mujer para llegar al matrimonio como lo establecieron los europeos. Los cronistas de indias muestran asombro ante tales costumbres, sobre todo en la libertad de las mujeres para vivir su sexualidad, así lo hace ver López de Gómara (2003), refiriéndose a las mujeres de Cumaná: "No se les da nada por la virginidad"(p.92), de igual manera Fernández de Oviedo al referirse a las costumbres de los indios resalta que la mujer guarda fidelidad a quien ella considere que lo debe hacer y que para las mujeres jóvenes es normal la práctica del aborto:

después que conocen algún cristiano carnalmente, le guardan lealtad sino está mucho tiempo apartado o ausente, porque ellas no tienen fin a ser viudas, ni religiosas que guarden castidad. Tienen muchas de ellas por costumbre que cuando se empreñan toman una yerba con que luego mueven y lanzan la preñez, porque dicen que las viejas han de parir, que ellas no quieren estar ocupadas para dejar sus placeres, ni empreñarse, para que pariendo se les aflojen las tetas, de las cuales mucho se precian..." (Gonzalo Fernández de Oviedo, 1950, p.122).

En cuanto a la maternidad, esta se convirtió en la condición biológica que garantiza una posición social preferente para la mujer a diferencia del hombre, quien ahora se ve en la necesidad de legitimar los hijos, de tal manera que se hace necesario implantar una institución en la cual se garantice la paternidad y así mismo garantice que los bienes familiares se conserven al interior de esta. Es entonces que se ve la necesidad del matrimonio monógamo, que durante la Colonia fue una institución sólo generalizada a nivel de la clase dominante española y criolla, y permitía blindar a la clase social de emparentarse con personas de grupos sociales dominados. Sin embargo para conservar este mismo orden en toda la sociedad se fue haciendo extensivo para los indígenas y luego los negros, aunque con estos últimos el matrimonio estaba sujeto a las conveniencias económicas de los amos, como lo señala la historiadora Ermila Troconis de Veracoechea (1984):

A pesar del interés de las autoridades civiles y eclesiásticas por mantener ciertas normas de moralidad, al promover los matrimonios entre esclavos, evitando así en lo posible las uniones ilícitas entre ellos, la realidad socioeconómica se imponía y muchos dueños de hatos y haciendas se oponían a la legalización de esas uniones. Esto se debía a que si se producía un casamiento 
entre esclavos de distintos amos, se planteaba el problema de que la mujer debía vivir en el mismo 'repartimiento' donde habitaba el marido, lo cual entorpecía su trabajo dentro de las propiedades de su amo. En algunos casos, éste prefería espontáneamente venderla al dueño del marido ${ }^{11}$.

Aunque la familia y el hogar constituían el sitio por excelencia de la mujer, el matrimonio de carácter patriarcal no le otorgaba casi ninguna compensación, la cual ni siquiera podía elegir su pareja, ya que los matrimonios a menudo eran pactados por los padres de los novios, lo cual convierte al matrimonio en un acto ritual, sin amor ni consenso, en el que prevalece la conveniencia económica y la garantía de la descendencia y el traspaso de la herencia a los hijos legítimos, dándole continuidad al patriarcado. Se fijaba una dote o contribución de la mujer al matrimonio, con el fin de garantizar un "buen matrimonio" para la hija; dote que, además, creaba una categorización social para las mujeres y garantizaba la estabilidad y fidelidad de parte de estas hacía sus maridos.

Paralelamente, los conquistadores europeos introdujeron en el nuevo mundo el concepto machista aristotélico de que el verdadero generador de la vida es el hombre, que provee con su esperma la materia viva, mientras que la mujer es solamente la receptora del esperma, lo que la convierte en un sujeto pasivo, cuya función es propagar la especie, lo cual se hará al interior del matrimonio, donde las mujeres, especialmente blancas y mestizas, se fueron haciendo inconscientemente reproductoras del sistema de dominación patriarcal al ser amas de casa y educadoras de sus hijos, lo que se consideraba eran sus principales tareas y de donde se desprendían sus valores en la sociedad. De manera que la familia blanca y mestiza es el espacio de lo que se considera privado, pues allí se da la procreación, la formación inicial de los hijos y es allí donde la mujer se hace importante, aunque en las comunidades indígenas la familia tenía un carácter público pues hacía parte del clan, lo que estos grupos intentaron mantener durante la colonia.

En este mismo contexto de la familia constituida sobre un modelo patriarcal, se establece el terreno de confrontación entre el poder del hombre y la sumisión de la mujer y su dependencia económica de este. Una muestra de trato patriarcal que daba la sociedad a la mujer son los

\footnotetext{
${ }^{11}$ Troconis de Veracochea, E. (1984) "Aspectos generales de la esclavitud en Venezuela". Revista Tierra Firme, (8). p. 445. Recuperado de: http://www2.scielo.org.ve/
} 
diversos manuales didácticos, escritos por clérigos para la educación de las mujeres como esposas ideales. Algunos de estos manuales citados por Asunción Lavrin (1985) son: Jardín de nobles doncellas de Fray Martín de Córdoba en el que enseña reglas de conducta para seguir siendo una buena mujer; textos como el ensayo escrito por Fray Hernando de Talavera con expresiones como: "el hombre es "en todo y por todo más perfecto que la mujer", y como consecuencia, es razonable que las mujeres sigan y obedezcan en todo las decisiones de los hombres" (p.37), y finalmente el texto que se convirtió en manual para todas las jóvenes esposas "La perfecta casada" de Fray Luis de León, quien invita a las esposas a conservarse puras y fieles para sus maridos y ayudarles en la administración de los bienes, así como dedicarse a la práctica de la oración y la caridad.

De otra parte la sexualidad sólo era permitida en el matrimonio, pero se puede decir que a medias, pues la sexualidad se permite siempre y cuando se realice en función de la procreación, es decir, de la supervivencia de la especie. El historiador Ricardo Rodríguez Molas, cita en su libro "Divorcio y familia tradicional" (1984) un manual para casados en el cual Fray Luis de Granada recomendaba en 1556 a los hombres: "usarás del matrimonio con toda honestidad conforme al fin que se ordena (...) aquel acto carnal se ordena a la multiplicación del linaje humano para que no se venga a acabar"(p.16), igualmente cita al religioso Pablo de León quien en 1553 en su libro Guía del cielo, expone: "la simple fornicación no es sino conjunción para engendrar" (p.16). De esta manera, basándose en el criterio de que el matrimonio es sólo para la procreación, los españoles trataban de casarse con adolescentes ya que mientras más jóvenes fueran las mujeres para matrimonio, mayor era el tiempo disponible para aumentar la descendencia, por eso se hacían frecuentes las uniones entre hombres mayores, incluso de más de cincuenta años con jóvenes quinceañeras, obligadas a casarse por la fuerza y por la imposición de los padres.

Es así que finalizando este apartado se puede ver que la Iglesia Católica junto con los conquistadores europeos fueron portadores de formas de opresión y normalización de la vida sexual de los habitantes del nuevo mundo, con enseñanzas como la virginidad de la virgen María, que en un primer momento se hace algo inentendible para los indígenas, pero que luego se va incorporando como la madre para los desprotegidos, de manera que aunque los indios talvez no 
entendían como podía ser madre de Dios, si la veían como la mujer madre y para ellos fue más accesible que el Dios crucificado, por tanto se le dan muchas significaciones como: "auxiliadora de los pobres, "consuelo de los débiles", "madre de los huérfanos", etc. Sin embargo detrás de todas estas significaciones se encuentra también un modelo de femineidad, pues es María la mujer sin mancha, sin pecado concebida, mediadora de la salvación, madre de Dios y ejemplar, por lo tanto es completamente el reverso de Eva, quien cedió a sus caprichos y desobedeció a Dios.

\subsection{Los temas sexuales}

\subsubsection{La doble moral}

En cuanto a la sexualidad, la influencia de las religiones y de la cultura, determinan que se den ciertas normas o preceptos en cuanto a los comportamientos sexuales de cada individuo, Freud (1981) argumenta que: "Nuestra cultura descansa totalmente en la coerción de los instintos" (p.1252), lo que genera en el individuo una renuncia a comportamientos y tendencias derivadas del erotismo, de tal forma que estas renuncias determinan su forma de ser y relacionarse con la sociedad, así como establecer unos comportamientos que se caracterizaran como morales e inmorales de acuerdo al criterio dado por la sociedad y las creencias religiosas.

Freud considera que: la religión, ha sido un mecanismo que sanciona y pone límites a todos los instintos y que considera las renuncias que hace el hombre en cuanto a lo erótico, como una ofrenda o sacrificio a Dios y expone como sagrado la conducta resultante. (Freud, 1981). De esta manera el individuo renuncia constantemente a la sexualidad que es una fuerza bastante grande presente en su ser y en cambio la canaliza hacia una finalidad distinta, lo que distingue Freud como "sublimación”, que a su vez le implica al ser humano un gran gasto de energía al estar constantemente haciendo el ejercicio de encaminar el instinto sexual hacia un fin totalmente distinto y que al final causará en el ser humano una serie de enfermedades neuróticas y padecimientos nerviosos.

Por otra parte la sexualidad se ha considerado en función de la reproducción por encima de la consecución del placer, lo cual constituye una renuncia aún más profunda, además de esto a 
los individuos se les pide ejercer su sexualidad solamente con una persona y con ella para toda la vida, teniendo como finalidad la procreación. Es así que gran parte de la excitación sexual presente en los seres humanos debe ser reprimida o canalizada y solamente una pequeña parte se utiliza para el esporádico acto sexual. Freud (1981) expresa que: "La "doble" moral sexual existente para el hombre en nuestra sociedad es la mejor confesión de que la sociedad misma que ha promulgado los preceptos restrictivos no cree posible su observancia”. (p.1256). Es entonces que la mayoría de individuos sigue unas costumbres aceptadas, pero en su interior sienten y quisieran hacer totalmente otras y aún más pregonan algo y hacen totalmente lo contrario. Esta dinámica se repite en las relaciones sexuales, ya que según los preceptos religiosos son solamente válidas las relaciones que se dan al interior de los contratos sociales o religiosos consagrados como matrimonios, con ceremonias y celebraciones fastuosas, pero en la realidad se mantienen relaciones sexuales ocultas y en muchas ocasiones inseguras porque la vida sexual inicia cada vez a más temprana edad y sin atender los cuidados personales, todo esto con el fin de guardar en lo externo las reglas sociales. Un claro ejemplo de estas reglas sociales y religiosas impuestas como conductas morales incluso a los grupos no confesionales, son las que tienen que ver con el uso de preservativos, el aborto, las relaciones fuera del matrimonio y las diversas formas de prostitución.

Por otra parte está la mujer quien de una forma más estricta se ve oprimida por las normas y preceptos culturales que le llevan a vivir su pulsión sexual con miras al matrimonio y solamente en función de la procreación. Para Freud (1981) es evidente que: "el matrimonio ha cesado de ser hace mucho tiempo el remedio general de todas las afecciones nerviosas de la mujer" (p.1257), además que para la mujer es mucho más difícil buscar mecanismos de sublimación, pues toda su humanidad se debe orientar hacia la vida matrimonial y maternal. Pero como el matrimonio no es suficiente para satisfacer el instinto sexual femenino, entonces se hace necesario buscar nuevas alternativas como la infidelidad conyugal que también supone una desventaja para la mujer frente al hombre, pues culturalmente la infidelidad masculina ha sido asociada con la hombría del individuo, mientras la infidelidad femenina simplemente no es aceptada culturalmente, pues la mujer se debe asociar al hogar y la educación de los hijos, lo cual supone una contradicción con la infidelidad. 
Por lo tanto la misma sociedad cae en la doble moral, pues no es capaz de mantener unas mismas normas y juicios para hombres y mujeres, pues acepta en ellos ciertas conductas que en ellas se consideran perjudiciales para el sostenimiento de la familia y por ende de la sociedad, por lo tanto la mujer hace un esfuerzo mayor al del hombre al buscar sublimar su impulso sexual en función de la familia, lo cual la lleva a encaminar hacia sus hijos toda su afectividad, sin embargo esto no alcanza para satisfacer el impulso sexual femenino y esto mismo le lleva a lo que llama Freud la nerviosidad moderna.

\subsubsection{Tabús}

La palabra tabú ha sido sinónimo de lo que se puede considerar como prohibido o inicialmente como algo peligroso, por lo tanto el tabú se puede relacionar con lo religioso y en nuestra sociedad de tradición cristiana se puede decir que está intrínsecamente relacionado con las normas, las prohibiciones, los preceptos y la forma de comportarse, es decir da una disciplina para ser aceptado en la sociedad y al mismo tiempo va configurando una organización familiar, como base de aceptación social. Esta aceptación se da desde el momento del nacimiento y va construyendo una identidad desde la diferenciación de los sexos y el papel de estos desde la religión, así como las actitudes, los valores, la forma de pensar y actuar de acuerdo al sexo de la persona. Es decir que el primer tabú desde lo religioso es la identidad y el rol que se le da a cada persona según su sexo, determinando una forma específica de comportarse y mostrarse dentro de la sociedad.

Desde la tradición judío-cristiana ha sido evidente que muchas de las prescripciones se han dado hacía la mujer, específicamente hacía la sexualidad, la menstruación, el embarazo y el post-parto. Según la antropóloga Carmen Castilla estas prescripciones encaminadas a la diferenciación de la mujer y el hombre se dan desde los ritos de los sacramentos (Castilla, 2009), iniciando con el bautismo en el cual se da el nombre, con lo que se integra el individuo a la sociedad, ya que el nombre da una identidad personal y sexual al niño y a la niña, dándole por otra parte una identidad social.

Con el concilio de Trento se hizo énfasis en que los sacramentos acompañaran la vida de las personas y fueran signos presentes en la vida de los fieles; uno de los sacramentos en los que 
más se insistió fue en la Eucaristía y la iniciación en él, la primera comunión, que a partir del siglo XVII se convertirá en un ritual público, para la antropóloga Carmen Castilla (2009): “El rito de la primera comunión adquiere entonces un significado social al marcar el paso de la niñez a la juventud" (p.3), sin embargo es en el siglo XIX que este rito se populariza y se convierte en un signo social para el niño que ahora pasa a ser joven, puesto que a quien recibe por primera vez la comunión se le permitirá sentarse en la mesa principal, servirse él mismo los alimentos y en el caso de los muchachos se pueden colocar pantalón largo oscuro, en el caso de las niñas se visten de blanco para recibir la comunión, y este color se considera signo de pureza, que se relacionará con el culto de la Inmaculada Concepción, dogma proclamado en 1854 por el papa Pio IX, dogma que considera que la única mujer que no tiene pecado original es la virgen María. Al vestir las niñas de blanco se da el mensaje de querer ver a las niñas como pequeñas réplicas de la virgen María, quien es la mujer ideal en el cristianismo, porque se considera libre de pecado, además ser modelo a seguir como ejemplo de pureza y virginidad. Así entonces la niña pasa a ser vista como mujer cuyo valor virginal debe ser guardado y solamente perdido al interior de otro sacramento: el Matrimonio.

En este sentido, el cristianismo ha considerado como tabú mantener relaciones fuera y antes del matrimonio, esta prescripción aplica especialmente para la mujer quien se debe mantener pura y virgen hasta el matrimonio, lo cual es fundamental para ser considerada una "mujer decente", así mismo, también se considera tabú hablar sobre ello y aún más que la mujer tenga un papel activo en la vivencia de su sexualidad, considerando el sexo como actividad realizada por los hombres para su exclusivo placer. Las mujeres, sujetos pasivos de dicha actividad, bajo la mirada de la religión deben cumplir con sus deberes conyugales prestándose a los requerimientos sexuales de su pareja, sin encontrar placer en el contacto sexual, pues la sexualidad femenina está estrechamente ligada con la procreación y la maternidad, de donde también salen formas de comportamiento propias de las mujeres, como son la ternura, la dulzura y la entrega incondicional a sus hijos, aún por encima de sus propios gustos y necesidades.

Retomando lo dicho al inicio de este apartado sobre los tabúes que tienen que ver con la menstruación o con el post-parto, en diferentes culturas y sociedades el paso de niña a mujer y la aparición de la menstruación tiene a su alrededor una serie de creencias y costumbres que van 
encaminadas a enseñar a la niña que desde que aparezca la menstruación se debe preparar para guardar una serie de preceptos con relación a este momento del ciclo vital, en palabras de Castilla (2009): "las niñas aprenden que cuando empiezan a menstruar su mundo cambiará para siempre" (p.5), pues los tabúes menstruales o las costumbres relacionadas con la menstruación tienen formas generalmente negativas. Estos tabúes van desde los que requieren el aislamiento de la mujer menstruante, hasta los que consideran la sangre menstrual como un líquido peligroso y venenoso, pasando por los que prohíben las relaciones sexuales en este período, los que prohíben a la mujer menstruante preparar o consumir determinados alimentos bajo el riesgo de contaminarlos, o los que impiden visitar lugares sagrados o tomar parte en liturgias religiosas. En la Biblia, el libro del Levítico dedica el capítulo XV a las impurezas de la menstruación, el estado menstrual es considerado como una inmundicia e indica que la mujer menstruante debe ser aislada, pues se considera que el estado menstrual es capaz de transmitir esta condición a cualquier objeto o persona que se ponga en contacto con la mujer en aquellos días.

Por otro lado, existen culturas donde es también muy frecuente el tabú posparto, las mujeres tras dar a luz, tienen que evitar las relaciones sexuales durante un período de tiempo culturalmente determinado. Además y también relacionado con determinados momentos del ciclo vital femenino encontramos normas alimenticias impuestas desde la religión. Así, hay culturas en las que por cuestiones religiosas, en determinados momentos tales como la gestación, el puerperio, la lactancia y la primera infancia, las mujeres no pueden ingerir una serie de alimentos considerados prohibidos.

Así, entonces desde el punto de vista de las religiones, la sexualidad, y todo lo que tenga que ver con ella, sean personas o situaciones, son temas tabú, cuestiones inamovibles cobijadas bajo los preceptos religiosos.

\subsubsection{Pecado}

En la revelación bíblico-cristiana, el pecado se interpreta como una negativa contra la divinidad, lo cual es una interpretación común con otras religiones. En el cristianismo se encuentra una visión de Dios que da un paso más que en la revelación bíblica, esta revelación es 
la dada por Jesús de Nazaret mediante sus enseñanzas y obras. A continuación se hace un acercamiento en lo relativo al pecado desde la tradición bíblica:

En la revelación bíblica la primera toma de conciencia sobre el pecado se da sobre los opresores de Israel en Egipto a quienes Moisés confronta, luego esa misma opresión fue apareciendo de distintas formas al interior del pueblo de Israel: idolatrías a varios dioses, monarquías basadas solo en el poder, ricos, ajenos e insensibles a los clamores de los más pobres, lo cual lleva a concluir que el pecado no es algo propio solamente de Egipto, sino que está en el corazón de todos los hombres "el corazón del hombre es lo más retorcido" (Jr 17,9), ante lo cual se advierte que el pecado es de todos y se plantea entonces el pecado de los orígenes presente en el texto del capítulo 3 del génesis, lo cual lleva a dar universalidad al pecado.

Esta universalidad del pecado es objeto de análisis por Pablo en la carta a los Romanos, donde plantea Pablo que el pecado es "aprisionar la verdad con la injusticia" (Rom 1,18), lo cual sería contrario a la verdad de Dios de vivir en el amor y la justicia, que se constituye en una misión para todos y al no hacerlo entonces los hombres "son inexcusables" (Rom 1,20), esta universalidad también incluye a los cristianos.

El pecado como traspiés, tropiezo, desviación de lo que Dios mismo interiormente sugiere, es posibilidad de todos los hombres. Criaturas llamadas a ser más de lo que somos, con anhelos profundos de justicia y con deseos egoístas de seguridad, fácilmente frustramos nuestra vocación. El pecado no es una necesidad del hombre salido de manos de su creador con defecto de fábrica; no es la naturaleza humana la que está contaminada; el pecado sobreviene cuando los hombres ejercen su libertad en la historia. (Espeja, 2002, p.111)

El pecado no es ajeno a ningún hombre por eso también la revelación de Dios a través de Jesús es para todos los hombres.

Siguiendo en el Antiguo Testamento, se encuentra otro momento en el que se da una nueva connotación al pecado, es bajo la Alianza en la que Yahvé promete a su pueblo ser fiel, es decir hace un compromiso de amor con ellos y así el pecado es la infidelidad contra el amor de Dios, es decir una falta de correspondencia y desamor contra Dios y contra el prójimo también incluido en la alianza, y contra el mismo pecador que se aparta de su verdadera vocación (ser fiel 
a Dios al pertenecer a su pueblo). Esta nueva connotación de pecado cambia la percepción que inicialmente hay del mismo ya que ahora no es una cuestión inherente a todos los seres humanos, sino que es una elección libre de cada uno permanecer fiel o no a Dios y la alianza con su pueblo. En el Nuevo Testamento esta alianza de Dios con los hombres se renueva por medio de Jesucristo de una manera definitiva, así los cristianos "permanecen en Cristo" (Jn 15,5) y el pecado es rechazar el favor que Dios le ha concedido en el bautismo, es decir volver a la esclavitud antigua.

En el contexto de la presente investigación se encuentra que el pecado entró al mundo por medio de Adán y Eva, como consecuencia de su desobediencia al mandato de Dios y encuentra su contraposición a esta desobediencia en la docilidad y obediencia de María mediante su "fiat" en la anunciación, que se extendería por toda su vida mediante la figura de la mujer entregada a su marido y a su hijo Jesús, permaneciendo obediente y virtuosa en su hogar sin ni siquiera preguntar o dudar de su misión frente a la de su hijo.

Con la primera pareja de pecadores tradicionalmente se ha entendido su pecado como inherente a la sexualidad y esta se expresa en los rasgos definitivos del pecado: contra la verdad de Dios: en Gn3,6 en la narración de la caída del hombre se presenta que este no acepta a Dios como Señor único y absoluto al atreverse a desobedecer, se puede entender entonces la sexualidad como la capacidad del ser humano de ser dueño absoluto de sus emociones y sus pasiones y desconocer su dependencia de Dios; contra la verdad del hombre: en el relato de la creación es claro que el hombre es una creatura hecha a imagen y semejanza de Dios, pero totalmente dependiente de él, cuando el hombre pretende ser Dios se vuelve contra sí mismo porque necesariamente esta conducta se traduce en dominación sobre los demás que también son imágenes de Dios, sin embargo pareciera que esta conducta de dominación es tolerante y hasta mandato de Dios frente a la mujer "tantas haré tus fatigas cuantos sean tus embarazos: con dolor parirás los hijos. Hacia tu marido irá tu apetencia, y él te dominará” (Gn3,16); contra la comunidad: con la desobediencia de Adán y Eva se hacen agresivas las relaciones entre ellos como pareja pues se establece una continua dominación y necesidad de liberación e igualdad de parte de la mujer, entre los humanos y la creación porque la pareja se debe someter a unas leyes naturales, e incluso el trabajo que se interpreta como castigo y la fuente de sustento de la familia, 
pero indicado solo para el hombre, quien aprovechará su situación de proveedor para dominar y someter a la mujer.

\subsubsection{Infidelidad}

Desde el cristianismo la infidelidad se entiende como la desobediencia a Dios y el culto a otras divinidades o prácticas religiosas distintas a las establecidas por la religión cristiana. Para la presente investigación se verá el concepto de fidelidad desde la pareja y desde el matrimonio, como el centro de amor mutuo entre hombre y mujer que se entregan desde su propia voluntad y forman una comunidad de vida donde ya no son dos personas sino una sola realidad ya que las dos personas deben dejar de lado algo de sus actividades e intereses y entregarse al otro para sostenerse mutuamente. Sin embargo el matrimonio como sacramento en el cristianismo tiene otra finalidad: la procreación, no solamente como el acto mismo de transmitir la vida, sino también como el fruto del amor de la pareja manifestado en los hijos, quienes vienen a reafirmar el compromiso adquirido por la pareja en el matrimonio. Compromiso que visto desde el sacramento del matrimonio es el consentimiento libre y mutuo de los esposos y visto desde la fe, en palabras de Jesús Espeja (2002): “el amor conyugal es asumido en el amor divino y se rige y enriquece por la virtud redentora de Cristo y la acción salvífica de la Iglesia” (p.155), así entonces si el matrimonio es prolongación del amor de Cristo por su Iglesia, entonces la pareja se compromete en fidelidad perpetua, servicio desinteresado, respeto hacia el otro y respeto de su libertad, no como imposiciones sino como exigencias dadas desde el propio sacramento y aceptadas desde la voluntad de la pareja.

La infidelidad entonces no es solamente que uno de los miembros de la pareja tenga relaciones sexuales con otras personas fuera de esta, sino el incumplimiento de su compromiso ante la fe, ante su cónyuge y ante la sociedad manifestada en los hijos.

En el cristianismo el adulterio es castigado por igual para el hombre y la mujer, ya que, según Jesús Espeja (2002): es un atentado contra el "templo del Espíritu Santo” (p.157), es decir el cuerpo y por tanto hombre y mujer están obligados a evitarlo. En nuestra cultura se puede encontrar que aunque la religión condena a los dos cónyuges por igual, la sociedad es mucho más drástica con la infidelidad si esta es cometida por la mujer y condescendiente con el hombre 
cuando es este el que es infiel, tal vez esta situación se da por la misma educación que se da al interior de las familias y la diferencia de roles y responsabilidades que se le dan a las mujeres y a los hombres, teniendo en cuenta que la mujer es el eje del hogar, sobre quien recaen todas las responsabilidades, la educación y el ejemplo de los hijos, mientras los hombres se educan para ser proveedores y solventar las necesidades básicas de los miembros de la familia, lo cual los hace más despreocupados y desprendidos del hogar, situación que de alguna manera justifica que el hombre fuera del núcleo familiar tenga otras relaciones. Mientras que si la infidelidad viene de parte de la mujer entonces inmediatamente se ve afectado el orden y la estabilidad familiar, así como el ejemplo y la educación de los hijos. 


\section{CAPITULO II \\ BIOPOLITICA Y SEXUALIDAD}

\subsection{Dominio de la vida}

Se puede distinguir en los trabajos de Michel Foucault como la sociedad controla y disciplina a los individuos, una sociedad que se preocupa por dominar al ser humano desde sus acciones antes de tener que castigarlo por ellas, es en el siglo XIX que se hacen grandes construcciones para retener allí a los que violan, a los que roban, a los que matan, la sociedad se siente orgullosa de sus cárceles porque estas reemplazan los espectáculos del patíbulo y el escarnio público del dolor del cuerpo para quien comete una falta; esta sociedad llega a maravillarse de no castigar ya los cuerpos y dedicarse en adelante a corregir las almas. Pero no solamente es la cárcel la garantía de encerrar para hacer dóciles a los individuos, también son necesarios el hospital, el ejército, la escuela, los talleres; es decir para cada momento de la vida se plantea un lugar para mantener vigilancia sobre el individuo a través de ejercicios, maniobras, calificaciones, rangos y lugares, exámenes, registros, como una manera de someter los cuerpos, dominar las diferencias humanas y manipular sus fuerzas, como la garantía para mantener la disciplina y garantizar un individuo dócil y sobre todo productivo. Son estas instituciones las que conforman toda una maquinaria de control de poder, de vigilancia continua sobre las libertades de las personas, hasta hoy día tener la habilidad tecnológica de conocer y controlar los movimientos, las relaciones, los gustos y hasta las conversaciones de cada uno de los individuos.

Del siglo XVI al siglo XIX se fue dando el gran paso hacia el reconocimiento de libertades individuales, pero al mismo tiempo se fue dando una evolución en la forma como el Estado controla y garantiza que el sujeto de libertades sea un sujeto productivo y controlado desde sus mismas libertades y esto se da desde la forma como la sociedad hace creer al hombre que es dueño de su vida, sus libertades y sus decisiones, mientras que el progreso y la tecnología lo van involucrando en un proceso de mecanización que involucra sus actividades, su toma de decisiones y lo lleva solamente a involucrarse en un mundo que le propone el progreso, el dinero, la productividad y el consumismo como la forma en la que está ejerciendo su individualidad.

En este capítulo se profundiza en el dominio y la represión física que se ejerce sobre los individuos, a través de diversas formas de control y represión. 
Teniendo en cuenta que el poder entre los hombres es una cuestión de naturaleza humana y ha estado presente a lo largo de la historia, es el primer tema que se desarrolla en este capítulo. Para lo cual se aborda el diálogo de Noam Chomsky y Michel Foucault (1971) en el cual se puede ver que para estos dos autores tan importantes en el siglo XX, el concepto de naturaleza humana es totalmente contrario y conlleva un desarrollo histórico y social distinto, de manera que Chomsky utiliza términos relacionados como "lenguaje innato o conocimiento instintivo" (p.8), ya que entiende la naturaleza humana como un "conjunto de esquemas o principios de organización innatos que guían nuestro comportamiento social, intelectual e individual” (p.8), todo ello entendido como algo innato, natural y biológico de los seres humanos, pero a su vez imposible de explicar científicamente. Chomsky se pregunta cómo es posible que sobre la base de un grupo de experiencias, los individuos sean capaces de aprender su lenguaje y usarlo de manera creativa?, ante lo cual responde a partir de sus análisis, que debe haber una cierta estructura biofísica en el pensamiento que nos permite tanto a individuos y a toda la especie llegar a unificar una cantidad de experiencias por medio del lenguaje, ante lo cual insiste que debe haber algo en la capacidad mental de todos los seres humanos que los lleve a hacer este tipo de unificación como es el lenguaje. (Chomsky, 2006)

Para Michel Foucault, siguiendo su metodología arqueológica, al no partir de conceptos sintetizadores asumidos a priori, el concepto de "naturaleza humana" no es muy claro y prefiere verlo desde la historia y la sociedad y no como un concepto universal, evitando la pregunta totalizante y abstracta sobre la naturaleza humana y reemplazándola por: cómo ha funcionado la naturaleza humana en nuestra sociedad? es decir prefiere ver como la naturaleza humana se ha materializado en prácticas económicas, tecnológicas, políticas, sociológicas que pueden llevarlo a dar una idea global del concepto, para lo cual toma las ciencias de la vida del siglo XVIII como ejemplo al tener en cuenta la clasificación y distinción entre los marcos conceptuales de "vida" y "naturaleza humana", que en su opinión tuvieron poca importancia en la forma como se dio el cambio y desarrollo propio de cada disciplina científica. Así para Foucault:

"no es por la naturaleza humana que los lingüistas descubrieron las leyes de la mutación consonante, o, Freud los principios de los análisis de los sueños, -los antropólogos culturales las estructuras de los mitos. -En la historia del conocimiento, la noción de naturaleza humana a mí me ha parecido principalmente haber jugado el papel de... designativo (designante) de ciertos tipos de 
discursos en relación a, o en oposición a, la teología, o la biología o la historia.”(ChomskyFoucault, 2006, p.9)

Con lo cual se nota claramente que desconfía de las verdades que se dicen universales, como sería en este caso el concepto de "naturaleza humana", que no contradice pero si busca darle explicación desde la historia, enfáticamente desde el estudio de las prácticas sociales, más no desde el abstracto del concepto.

Frente al problema de la naturaleza humana un segundo punto de opinión entre los dos autores es el de la política, que para Chomsky tiene que ver con el concepto universal -una vez más- de naturaleza humana desde la libertad y la creatividad, como una necesidad de todos los seres humanos de reaccionar a una situación nueva, es decir la curiosidad propia del niño, lo cual en la sociedad está reprimido por la tecnología y la ciencia: "la ciencia podrá abordar el problema de la creatividad normal e incorporarlo como un tema propio. Pero no creo que la ciencia, al menos en un futuro razonable -y sospecho que usted estará de acuerdo- pueda entender la verdadera creatividad" (p.14), que para Chomsky es un acto humano normal y hace parte de la naturaleza humana, que en la sociedad se encuentra reprimida por la organización social y política de esta misma y solo se puede cambiar con la búsqueda de una sociedad más justa guiada por la razón y la naturaleza humana.

Foucault defendiendo su planteamiento de no deducir desde los universales, en este caso la política, cambia la pregunta de por qué, por el cómo influye y se entiende la política, como un problema de la sociedad en que vivimos, su economía y las formas de poder presentes en nuestra sociedad ya que para Foucault (2006): "la esencia de nuestra vida consiste en el funcionamiento político de la sociedad en la que nos encontramos" (p.22), lo que se evidencia en el control del poder social que oprime y reprime, en palabras de Foucault (2006): “es una costumbre considerar, al menos en la sociedad europea, que el poder está en manos del gobierno y que se ejerce a través de ciertas instituciones determinadas, como la administración, la policía, el ejército y los aparatos de Estado" (p.23), ante lo cual el llamado de Foucault es a criticar desde la política todas las instituciones que ocultamente se han convertido en instrumentos de control y violencia política, sin que en su naturaleza esté el desarrollar esta tarea de control y esta tarea crítica se debe desarrollar desde el desenmascaramiento de las clases dominantes y sus intereses 
en cuanto a la dominación en términos políticos y la explotación económica. Contribuyen en esta dominación también las ciencias humanas, que han construido discursos basados en enunciados que benefician a unos cuantos e invisibilizan a muchos otros.

A este respecto Chomsky (2006) se muestra de acuerdo, pero añade dos tareas intelectuales al respecto, primera: "crear una teoría social humanista" (p.24), a fin de crear una sociedad donde sea posible la justicia, como parte importante de la naturaleza humana; segunda: “comprender cabalmente la naturaleza del poder" (p.24), que además conlleva terror, destrucción y opresión en la sociedad. Esto además llevaría a comprender la forma como las instituciones propias de nuestra sociedad, como son las instituciones sociales, financieras y económicas ejercen opresión y poder sobre la sociedad, y lo hacen desde las fuerzas de mercado en una sociedad no igualitaria. Sin embargo y a pesar de todas las dificultades que supone una sociedad totalmente consumista, Chomsky no renuncia a entender la naturaleza humana como libertad, dignidad, creatividad y desde allí la construcción de una estructura social donde sea posible la realización de la libertad, dignidad y creatividad como sentido pleno de la naturaleza humana.

En esta investigación se tendrá en cuenta la visión de Foucault partiendo del análisis histórico de las relaciones de poder entre los hombres que en todas las culturas se han configurado desde la dominación tanto de territorios, costumbres e imposición de una cultura ajena.

$* * *$

En esta misma línea de análisis de pensamiento de Michel Foucault la investigación se centra en este apartado en el estudio de los lineamientos teóricos que definen su enfoque político y que servirán para hacer un acercamiento a su visión del poder.

Para el marxismo el poder debe estar centrado en el Estado, quien garantiza la dominación del capital sobre el trabajo a través de la existencia de la propiedad privada de los medios de producción, para Foucault el poder no se encuentra concentrado en el Estado y su aparato represor representado en la policía, sino que el poder circula por toda la sociedad, ya sea desde el médico, el político o el psicólogo, siempre y en todas las sociedades se ha encontrado, lo que manifiesta Foucault (1996): "intentamos hacer aparecer aquello que ha permanecido hasta ahora 
más escondido, oculto y profundamente investido en la historia de nuestra cultura: las relaciones de poder" (p.29), de manera que la dominación y explotación capitalista y su manifestación en las relaciones de poder, no se encuentra solamente en el poder policial cuando reprime las protestas sociales contra el orden dominante y garantiza el dominio del capitalismo, sino que se hace presente en todas las relaciones sociales ya sean presentes u ocultas, conscientes o inconscientes e incluso las relaciones que se consideran como privadas, son relaciones que se pueden considerar políticas, ya que en todas ellas hay relaciones de poder y dominación de unos sujetos sobre otros. Esto es lo que llama Foucault "micropoderes", de manera que el poder no se encuentra en manos de una persona o un grupo particular, como sería la clase capitalista, sino que se ejerce de manera relacional y trasversal en toda la sociedad, siendo el poder "micro" pues en la mayoría de ocasiones no es observable, aunque circula a través de las instituciones como los hospitales, manicomios, las escuelas y las cárceles y en todas las relaciones de poder en las que se evidencia que toda relación entre los hombres es también una relación política.

Michel Foucault encuentra el poder presente en todas las relaciones de la sociedad, pero también encuentra que hay revolución y toma de poder, al igual que lo plantea el marxismo; pero esta revolución no solamente se alcanza con la lucha violenta contra el sistema capitalista, sino que debe alcanzar una transformación por medio de la continua lucha contra las diversas formas de dominación en las relaciones sociales, los diversos micro-poderes que se encuentran en las instituciones como las escuelas, los hospitales, los manicomios, las cárceles y que permiten la perpetuación de los mecanismos de dominación de orden gubernamental, lo que expresa Foucault (1990): "es sin duda prudente no tratar acerca de la racionalización de la sociedad o de la cultura como un todo, sino analizar ese proceso en varios dominios, que se arraigan cada uno de ellos en una experiencia fundamental: locura, enfermedad, muerte, crimen, sexualidad, etc" ${ }^{12}$.

Distingue Foucault formas de lucha ante esta sociedad: la lucha por el discurso y la lucha por las prácticas microscópicas de dominación del sistema, en estos dos campos hay varios tipos de disciplinamiento de la sociedad, que se imponen por medio de discursos y prácticas que asignan a los individuos cómo pensar, qué decir, cómo actuar, cómo y cuándo hablar. Es hacia

\footnotetext{
12 Foucault, M. (2010,02).Omnes et singulatim: hacia una crítica de la «razón política. Recuperado de: http://estafeta-gabrielpulecio.blogspot.com/
} 
estas prácticas muy presentes en la sociedad hacia las que se debe volcar según Foucault el objeto de lucha política. Esta lucha no implica en lo absoluto la vía violenta, esta lucha se logra según Foucault no solamente siguiendo el camino iniciado por Kant en cuanto a la invitación de dejarse guiar por la razón para salir de la minoría de edad, sino que plantea un cambio de actitud, lo que Foucault llama (2006) "un ethos filosófico que se podría caracterizar como crítica permanente de nuestro ser histórico"(p.87), de manera que la crítica se hace desde los límites de la modernidad para traspasar los límites impuestos por esta, en palabras de Foucault (2006):

Se debe evitar la alternativa del afuera y del adentro, hay que estar en las fronteras. La crítica es en verdad el análisis de los límites y la reflexión sobre ellos. Pero si la cuestión kantiana era saber qué límites debe renunciar a franquear el conocimiento, me parece que la cuestión crítica hoy debe ser invertida como cuestión positiva: en lo que nos es dado como universal, necesario, obligatorio, cuál es la parte de lo que es singular, contingente y debido a coacciones arbitrarias. Se trata, en suma, de transformar la crítica ejercida en la forma de la limitación necesaria en una crítica práctica en la forma de franqueamiento posible" (p.97)

Así entonces la crítica que plantea Foucault busca revisar las estructuras formales que históricamente han tenido un valor universal, no para escapar del sistema, sino hacer una revisión histórica que permita hacer visibles lo que llama Foucault (2006): "los acontecimientos que nos condujeron a constituirnos, a reconocernos como sujetos de lo que hacemos, pensamos, decimos" (p.97).

\subsection{Dominio del cuerpo}

Para el segundo momento de este capítulo se hará un análisis del cuerpo y sus diversas visiones en la filosofía, iniciando esta revisión desde la Grecia antigua con base en la visión de Platón, Epicuro y los Estoicos.

En Fedón o diálogo sobre el alma, sobre las últimas horas de Sócrates, en un primer momento en el diálogo de Sócrates con Simmias sobre la inmortalidad del alma, se hace énfasis en la necesidad del filósofo de abandonar los placeres del cuerpo para dedicarse solo a su alma, que es la que le posibilitará un verdadero acercamiento a la ciencia ya que el buscar la verdad con el cuerpo lo conduce constantemente al error 
¿y no razona mejor que nunca cuando no se ve turbada por la vista, ni por el oído, ni por el dolor, ni por el placer; y cuando, encerrada en sí misma, abandona el cuerpo, sin mantener con él relación alguna, en cuanto esto es posible, fijándose en el objeto de sus indagaciones para conocerlo? (Platón,p.8-9)

Así se considera el cuerpo como un impedimento para llegar a conceptos como la justicia por ejemplo, ya que con ningún sentido ha llegado a conocer la esencia de ésta, ni de las demás cosas, por lo tanto es necesario acercarse a estas cosas solo por medio del pensamiento sin intentar utilizar los sentidos corporales, ya que el cuerpo constituye un obstáculo para el verdadero conocimiento: "el cuerpo nunca nos conduce a la sabiduría"(p.9), ya que las pasiones provenientes del cuerpo limitan el acercamiento a la filosofía y por consiguiente el llegar a la verdad, por lo tanto el alma sola se debe dedicar a acercarse a lo que quiere conocer para llegar a la verdadera sabiduría, lo cual plantea el autor se dará después de la muerte y no durante la vida a menos que se dé un alejamiento del cuerpo y de todas sus necesidades.

En un tercer momento del diálogo, esta vez con Cebes, se plantea la naturaleza del cuerpo y del alma, siendo el primero de naturaleza visible y material y el alma de naturaleza invisible e inmaterial y que se mantiene siempre lo mismo, mientras que el cuerpo se mantiene en continua mudanza, lo que considera el autor que el alma se acerca más a lo divino y el cuerpo se acerca más a lo mortal, obligándolo a ser obediente y esclavo del alma:

Mira, pues, mi querido Cebes, si de todo lo que acabamos de decir no se sigue necesariamente que nuestra alma es muy semejante a lo que es divino, inmortal, inteligible, simple, indisoluble, siempre lo mismo y siempre semejante a sí propia; y que nuestro cuerpo se parece perfectamente a lo que es humano, mortal, sensible, compuesto, disoluble, siempre mudable, y nunca semejante a sí mismo. (Platón, 2011, p.22)

De manera que el alma debe renunciar a todos los placeres del cuerpo, a sus deseos, tristezas y temores porque estos le llevan a experimentar los males sensibles comunes a todos los hombres y no dejan al alma abandonar totalmente el cuerpo al momento de la muerte.

La visión del cuerpo en Epicuro se basa en el cuidado de este para llegar a la felicidad, en la carta a Meneceo, señala que la salud es indispensable para llegar a tener una vida feliz "todo 
lo hacemos, para no tener dolor en el cuerpo ni turbación en el alma" ${ }^{13}$, por lo tanto el tener buena salud, como ausencia de dolor es la garantía de mantener una armonía entre el cuerpo y el alma, pero también es la aceptación del cuerpo al reconocer el placer como "el bien primero" por considerarlo algo natural y la base para toda elección, sin embargo no todos los placeres se deben elegir pues de muchos de ellos se sigue el dolor o "una molestia mayor", por eso algunos se consideran como un mal. El placer no es entendido como goce desmedido, todo lo contrario se considera como la satisfacción de las necesidades sin caer en excesos, pues estos no garantizan una vida feliz, es decir el goce es lo que permite: "no sufrir dolor en el cuerpo ni turbación en el alma”, por eso es importante practicar las virtudes de las que sobresale la Prudencia, esta para Epicuro se entiende: "la prudencia es incluso más apreciable que la filosofía; de ella nacen todas las demás virtudes, porque enseña que no es posible vivir feliz sin vivir sensata, honesta y justamente, ni vivir sensata, honesta y justamente sin vivir feliz", por eso el mantener el cuerpo sano y el alma tranquila se da desde la vivencia de las virtudes en el uso de los placeres, pues las virtudes garantizan el uso correcto de estos sin caer en los excesos que pueden causar dolores en el cuerpo.

El cuidado del cuerpo se convierte así en el principio más importante y ese cuidado se da desde el cuidado de uno mismo que se debe convertir en una actitud de toda la vida. Para Epicuro solamente la filosofía puede ser el ejercicio constante para el cuidado de uno mismo: "Que nadie, siendo joven, tarde en filosofar, ni siendo viejo se canse de la filosofía. Pues no es para nadie ni demasiado pronto ni demasiado tarde para asegurar la salud del alma"14. Esta misma idea del cuidado del cuerpo la toma Séneca y la transmite en una de sus cartas a Lucilio:

Así como un cielo sereno no es susceptible de una claridad más viva aun cuando, a fuerzas de ser barrido, reviste un esplendor que nada empaña, así el hombre que vela por su cuerpo y por su alma, para construir por medio del uno y la otra la trama de su felicidad, se encuentra en un estado perfecto y en el colmo de sus deseos. ${ }^{15}$

\footnotetext{
${ }^{13}$ López, C. (Febrero 2004). Epicuro: Textos. Biblioteca Virtual Antorcha. http://www.antorcha.net/biblioteca_virtual/filosofia/epicuro/epicuro.html\#2. Consultado: 13-octubre-13 ${ }^{14}$ Ibíd.

${ }^{15}$ Séneca, L. Epístolas de Seneca a su buen amigo Lucilio. Biblioteca Virtual Miguel de Cervantes. Consultado: 7-nov13
} 
En cuanto a los estoicos, inicialmente con Zenón consideran que Dios es el alma del mundo que lo rige todo con estricta determinación según sus planes. Por esta razón el hombre no puede modificar su destino y lo más lógico será conformar su voluntad con la divina, de allí que su norma ética sea "vivir según la naturaleza", es decir seguir esa razón universal que lo gobierna todo, por lo tanto es necesario dominar las pasiones para ser señor de sí mismo (autarquía) y no turbarse por nada (apatía). La virtud consiste en obrar razonablemente, en liberarse de todo lo que pueda esclavizar y conseguir la imperturbabilidad, de manera que la única libertad posible es obrar conforme a la razón.

En la Stoa nueva, retomando a Séneca se puede ver que la virtud es suficiente para la felicidad, de modo que todo lo demás como riquezas, placeres, vanidades no son necesarios y solo valen si están subordinados a la virtud. Sin embargo en la carta XIV a Lucilio reconoce la importancia del cuerpo y la forma como se debe tratar y atender, teniendo cuidado de no llegar a ser esclavo de este al exagerar con sus cuidados, sin olvidar que es necesario para vivir, pero siempre teniendo en cuenta la razón "Brindémosle el más diligente de los cuidados, reservándonos, si así lo exija la razón, la dignidad, la fe, el derecho de entregarlo a las llamas""16, por lo tanto también se debe mantener el cuerpo alejado de todo lo que atente contra él o represente algún peligro, esto Séneca lo muestra en tres aspectos: la penuria, la enfermedad, lo que se deriva de la violencia de los más poderosos, de estas tres la que más puede hacerle daño al cuerpo es la violencia proveniente de los otros teniendo en cuenta que cuanto más violento y doloroso sea el aparato de tortura que se utilice de manera que más sufrimiento pueda infringir al cuerpo más capacidad de sometimiento tendrá. Sin embargo los otros males como las enfermedades y las necesidades también son capaces de disminuir el cuerpo y el espíritu, pero no exhiben tanta crueldad como lo puede hacer la violencia proveniente de otros, por eso recomienda Séneca mantener el cuerpo libre de riquezas y elementos que puedan ser motivo de riña "A aquel que va desnudo, el ladrón deja pasar; incluso en el camino más mal frecuentado hay paz para el pobre" ${ }^{17}$.

\footnotetext{
${ }^{16}$ Seneca, cartas a Lucilio. Carta XIV. España. Editorial Juventud. http://www.editorialjuventud.es/1933.html. Consultado: 7-nov-.13

${ }^{17}$ Ibíd.
} 
Con el fin de mantener el equilibrio se deben evitar tres cosas: odio, envidia y desprecio, teniendo en cuenta que el caer en envidia puede llevar a despreciar y pisotear a otros corriendo el riesgo de ser también pisoteados y de allí pasar al odio. La mejor forma de alejarse de estos tres adversarios es siguiendo con "modestia y tranquilidad" las enseñanzas de la filosofía, que para todos, incluso para los malvados es honorable y no despreciable. Así se recalca una vez más que el cuidado del cuerpo se debe dar desde el cultivo de la razón y la dirección de las enseñanzas filosóficas. Es esta la tarea que debe seguir el sabio "cultivar el arte de vivir y ofrecer al género humano directivas de vida sin ofender a los poderosos"18 y no participar en política y evitar las extravagancias en su vida. Esto es el equilibrio que garantiza una buena salud, acompañada de la templanza para evitar emprender muchas empresas que perturban muchas veces el destino de los pueblos y no permiten ni siquiera el descanso adecuado y si propicia el desgaste del cuerpo.

Finalmente advierte el autor sobre el peligro de la riqueza "el que depende de la riqueza, teme por ella" y este temor atenta contra el equilibrio del cuerpo pues "A nadie sin embargo aprovecha una fortuna que inquieta"19.

En la carta XV como continuación de la carta anterior se hacen unas recomendaciones generales de cómo cuidar y mantener la salud; la primera recomendación es filosofar con el fin de mantener sano el espíritu y con esto el cuerpo también se mantendrá saludable y fuera de perturbaciones, sin embargo aquí advierte Séneca que es mucho más importante estar pendiente de la salud del espíritu para estar contento y equilibrado consigo mismo, mientras que cuando se dedica a ocuparse y cuidar mucho el cuerpo aunque se cultiven los músculos y se tengan muchas habilidades físicas no vale la pena concentrarse en estas actividades, lo cual expresa Séneca: "cuando contento de ti mismo hayas terminado de engrasarte y dilatar tus músculos, no habrás igualado ni el vigor ni la corpulencia de un buey gordo" 20 , por eso es mucho más importante el cultivo y el cuidado del espíritu que el cuidado del cuerpo.

Además, los ejercicios para ejercitar el cuerpo pueden ser muy agotadores, lo cual representa dificultad para concentrarse al realizar actividades de estudio, de igual manera cuando

\footnotetext{
${ }^{18}$ Ibíd.

${ }^{19}$ Ibíd.

${ }^{20}$ Seneca, cartas a Lucilio. Carta XV. España. Editorial Juventud. http://www.editorialjuventud.es/1933.html. Consultado: 7-nov-.13
} 
se ingiere demasiado alimento, sobre todo bebidas para reponer lo que se transpira con el ejercicio. Sin embargo propone el autor realizar unos ejercicios sencillos para aflojar el cuerpo y así facilitar la concentración en los estudios. La ejercitación del cuerpo debe ir encaminada a la salud del alma y a la conservación de la salud del cuerpo, según lo expresa Séneca: "Lo que sea que hagas, dirígete prontamente del cuerpo al espíritu, ejercita éste día y noche. Un esfuerzo moderado lo nutre, ni el frío ni el calor impiden su entrenamiento"21.

Para finalizar el texto propone Séneca a Lucilio tener cuidado de depender de la fortuna y no estar satisfecho de lo que se tiene, porque lo que se tiene es fruto del propio esfuerzo y de la propia superación de manera que no tiene sentido mirar a quienes están delante o detrás, ya que cada uno hace su esfuerzo y finalmente el esfuerzo propio no depende ni afecta el esfuerzo de los demás y lo importante es superarse a sí mismo, superar la debilidad humana que tiene la disponibilidad de amontonar, para lo cual se aspira a conseguir los bienes que más tarde pasan a ser un elemento más y acrecientan el deseo de poseer bienes, lo cual dificulta el cultivo del espíritu, según Séneca: "Instituye fronteras que no puedas franquear aunque quieras; que desaparezcan de una vez por todas esos bienes insidiosos, mejores cuando esperados que cuando alcanzados",22.

En un segundo momento de esta revisión sobre la visión del cuerpo se da paso a la cultura occidental, donde la visión de cuerpo que ha prevalecido es la visión heredada del cristianismo que plantea la pregunta: ¿Qué es el hombre? respondiendo desde el lenguaje bíblico encuentra que el hombre es una unidad que ni siquiera la muerte puede dividir y exalta primordialmente tres funciones del hombre, expresadas en sus órganos: su corazón, su lengua, sus manos, que manifiestan íntegramente al hombre. Sin embargo en las categorías habituales del cristianismo se encuentra aún el dualismo de la filosofía griega, como es posible ver en las enseñanzas que da el Catecismo de la Iglesia: "Dios creó al hombre a su imagen, a imagen de Dios lo creó, hombre y mujer los creó... en su propia naturaleza une el mundo espiritual y el mundo material" (1992. No. 354), considerando que el hombre es un ser corporal y espiritual, en donde el término alma según la sagrada escritura es la vida, el aliento de vida que Dios sopló en la nariz del hombre, al igual

\footnotetext{
${ }^{21}$ Ibíd.

${ }^{22}$ Ibíd.
} 
que es lo más íntimo del hombre, de tal manera que "alma” es el "principio espiritual" del hombre.

El cuerpo se encuentra animado por el alma espiritual y se considera "templo del espíritu" (1992. No. 363), considerando que la unión de alma y cuerpo se da cuando el alma le da forma al cuerpo: "gracias al alma espiritual, la materia que integra el cuerpo es un cuerpo humano viviente; en el hombre el espíritu y la materia no son dos naturalezas unidas, sino que su unión constituye una única naturaleza" (1992. No. 364).

De esta manera, después de hacer un recuento de como el cuerpo ha sido objeto de dominio en la cultura occidental, desde la antigua Grecia hasta nuestros días, y teniendo en cuenta que la enseñanza y tradición del cristianismo permea con sus enseñanzas sobre este tema, se puede entonces llegar a determinar que para los griegos el cuerpo es un elemento que ha sido visto bajo la subordinación de otro elemento, sea el alma, la virtud, la razón o la concentración en el estudio, es decir el cuerpo por sí mismo no tiene una validez propia, incluso se le considera incapaz de llegar a conocer el bien por medio de los sentidos, es decir el cuerpo es más bien un medio desde el cual el individuo puede llegar a alcanzar la virtud o puede llegar a ser mejor estudiante, para lo cual el cuerpo debe ser dominado e instruido rigurosamente en la alimentación, el ejercicio y solamente atendido en cubrir sus necesidades básicas.

Desde el cristianismo esta realidad del cuerpo no es muy distinta a la desarrollada por los griegos y también se puede encontrar que el cuerpo es inferior al alma quien es la responsable de darle la vida, además de ser de condición inmortal, lo cual la coloca sobre el cuerpo mortal que debe subordinarse a esta, ya que es en esta que el espíritu de vida que Dios sopla en el hombre se puede encontrar; así el cuerpo se continua entendiendo desde la visión dualista platónica, sin darle una identidad específica, sino más bien dependiente del alma, como responsable de darle la vida, además de verlo como inferior y por lo tanto se le debe educar y formar para que responda a los principios de vida dados por Dios a través del alma.

En el siglo XX Michel Foucault a través de la investigación de archivos históricos plantea que el cuerpo fue involucrado con la violencia, la sexualidad, la locura, la prisión, el saber y poder. Libros como Vigilar y Castigar, la Historia de la Locura, la Microfísica del Poder, dan 
cuenta de estas investigaciones sobre el cuerpo, así como la construcción de una historia que descubre los ocultamientos y las relaciones de poder que se van evidenciando en este, encontrándolo como "origen del origen" del poder y objeto de múltiples estrategias de disciplinamiento, para tal fin el cuerpo ha sido supliciado, torturado, desmembrado, además que se ha visto subordinado a minuciosos dispositivos y disciplinas que lo cercan, lo marcan, le imponen unos signos, se ve sometido a una sociedad disciplinaria la cual, emplea técnicas y procedimientos para formar individuos, lo cual se origina desde el hogar, el colegio y el trabajo como los lugares por excelencia donde se mantienen vigiladas las personas y se puede hacer un seguimiento o evaluación de todos sus movimientos y actitudes.

Es importante mencionar que además de esta relación estrecha entre el cuerpo y el poder, Foucault enuncia en la Arqueología del saber (1979) al referirse al cuerpo desde las formas del discurso, como "rejilla de especificación”, de la cual dice: “el cuerpo como volumen tridimensional de órganos que están unidos por esquemas de dependencia y de comunicación" (p.69); de tal manera que desde el discurso el cuerpo se entiende solamente como una masa en relación con el alma y con la vida y la historia del individuo.

En Vigilar y Castigar, plantea Foucault que el poder forma parte de la existencia del hombre, ya que es necesario y está presente en cualquier manifestación humana: en las relaciones laborales, en el mundo de la ciencia, la lectura, el matrimonio, en el sexo, en el arte, etc, y es en estas formas y prácticas sociales que el cuerpo entra a forma parte de lo que Foucault (2002) designa una "anatomía política" (p. 19), de manera que entre el poder y el cuerpo se establece una relación indestructible, pues es el cuerpo donde en primera medida se evidencia el poder y el instrumento de sumisión de este, como se demuestra en el siguiente apartado:

\subsubsection{El cuerpo y el Poder}

En el planteamiento filosófico de Michel Foucault el cuerpo se encuentra sumergido en un campo político en donde establece relaciones con otros cuerpos, relaciones que reciben el nombre de "Relaciones de poder", lo que expresa Foucault (2002): "Pero el cuerpo está también directamente inmerso en un campo político; las relaciones de poder operan sobre él una presa inmediata; lo cercan, lo marcan, lo doman, lo someten a suplicio, lo fuerzan a unos trabajos, lo 
obligan a unas ceremonias, exigen de él unos signos"(p.18), de tal forma que el cuerpo está imbuido en las relaciones de poder, no puede escapar a ellas, solo puede actuar dentro de estas relaciones, convirtiéndose en una presa inmediata del poder en sus múltiples dimensiones, desempeñándose como autor principal de las relaciones de poder.

De manera que para Foucault, el cuerpo desde lo más individual representa un pequeño poder, un micro-poder; que entra en relación con otros micro-poderes, que se manifiestan en diversos campos como son lo social, económico, político, religioso, cultural entre otros. De tales relaciones de los micropoderes, resulta la creación de normas, contratos, convenios, acuerdos, formas de propiedad, en fin, diversas relaciones que involucran al cuerpo. Así el cuerpo ha sido utilizado como objeto y blanco de poder; objeto en el sentido que ha sido visto y valorado como instrumento productivo, exigiendo algunos ejercicios y maniobras que lleven a tal fin, y como blanco de poder, porque se ha visto inmerso en un campo político, que lo envuelve en relaciones de dominio y sumisión. El cuerpo se encuentra involucrado como principal autor de las relaciones de poder, como las establecidas en el seno de un hogar, en donde se observa las relaciones de poder de los padres hacia los hijos y de éstos hacia los padres mismos. En esa misma dinámica se encuentra también el Jefe y el obrero y viceversa; el profesor y el estudiante y viceversa.

Por otra parte el cuerpo se encuentra en una sociedad que ha limitado el espacio para moverse, ha organizado el área, trazando fronteras para demarcar su territorio y así tener el control de él, para conservarlo siempre localizado, vigilado para mantener efectivamente la estructura de lo que Foucault (2002) considera es una "sociedad disciplinaria" (p.118), cuya norma de rendimiento está trazada por la observación del cuerpo; lo cual evidencia Foucault en el panóptico que por su arquitectura carcelaria no solamente opera en ese espacio para observar los movimientos de los presos desde cualquier ángulo, sino que fundamentalmente se puede considerar como una arquitectura de control social.

Se puede entonces apreciar la estrecha relación entre poder-cuerpo, como una de las tesis fundamentales de Michel Foucault, considerándose incluso que el poder es algo totalmente inherente al hombre, pues se mueve en él, vive en él y se relaciona en él, de manera que el poder 
se encuentra en el hombre mismo, en su existencia como tal, no está por fuera de él, no es algo externo que lo domina o subyuga. En esta misma relación cuerpo-poder el autor expone todo un saber sobre el cuerpo expresado en técnicas que fueron apareciendo en el estudio de la historia de la vigilancia y el castigo en épocas anteriores al desarrollo capitalista:

Es decir que puede existir un "saber" del cuerpo que no es exactamente la ciencia de su funcionamiento, y un dominio de sus fuerzas que es más que la capacidad de vencerlas: este saber y este dominio constituyen lo que podría llamarse la tecnología política del cuerpo. (Foucault Michel, 2002, p.18)

Esta tecnología política del cuerpo se refiere a ese saber del cuerpo en su inseparable relación con el poder, es el compendio de situaciones presentadas en las relaciones de poder, y de las que el cuerpo es el principal protagonista.

Otra tesis de las planteadas por el autor, desde nuestras sociedades es que el cuerpo es manipulado desde la infancia porque nos imponen un nombre: Carlos, José, María etc., unas creencias (litúrgicas), una educación (preescolar, primaria, secundaria, universidad etc.), nos incluyen en un estado político, al cual tenemos que someternos, al igual que a su gobierno y sus leyes; siendo así la sociedad donde se debe cumplir y acatar unas reglas, en la familia se educa a través de la disciplina para ser una persona de bien. En la calle cada individuo se debe comportar de acuerdo con su cultura, cada individuo es formado según los valores, es educado con el propósito que adquiera un saber y un poder para desenvolverse estratégicamente en las diferentes relaciones. El individuo es constantemente evaluado y corregido por otros individuos que ejercen el poder y a la vez son sujetos de este, lo que expresa Foucault:

Este poder, por otra parte, no se aplica pura y simplemente como una obligación o una prohibición, a quienes "no lo tienen"; los invade, pasa por ellos; se apoya sobre ellos, del mismo modo que ellos mismos, en su lucha contra él, se apoyan a su vez en las presas que ejerce sobre ellos (Foucault, Michel, 2002, p.18)

Pero este concepto de poder no se queda en la distinción de "quienes lo tienen" y de los que "no lo tienen"; porque el autor lo explica muy bien, el poder no es una propiedad, es decir, no es algo de la exclusividad de una persona o de un grupo determinado. Por lo tanto todos los individuos de una sociedad somos responsables del manejo del poder que se de en esta, 
precisamente porque cada uno de los individuos forma parte de la sociedad y se hace responsable de lo que en ella ocurra, por tanto el poder pasa por cada individuo, invade a todos los que pertenecen a la sociedad, invade a cada uno, le toca a cada uno, convirtiéndolo en objeto de poder y eso lo hace partícipe de las relaciones de poder presentes en las sociedades.

Otro planteamiento presente en Vigilar y Castigar es: la forma como el cuerpo también se utiliza como forma de disciplinamiento, es decir que se ve forzado a utilizar un sin número de movimientos corporales, actos, tácticas, estrategias, simbolismos, maniobras, etc, que lo llevan a establecer unas relaciones específicas con los demás cuerpos o micropoderes y lo llevan a concebir unas formas específicas de comportarse

El cuerpo humano entra en un mecanismo de poder que lo explora, lo desarticula y lo recompone. Una "anatomía política", que es igualmente una "mecánica del poder" está naciendo; define cómo se puede hacer presa en el cuerpo de los demás, no simplemente para que ellos hagan lo que se desea, sino para que operen como quiere, con las técnicas, según la rapidez y la eficacia que se determina. La disciplina fabrica así cuerpos sometidos y ejercitados, cuerpos "dóciles"” (Foucault, Michel, 2002, p.83).

De esta manera el disciplinamiento del que ha sido objeto el cuerpo humano lo ha llevado a involucrarse en innumerables conflictos a lo largo de la historia, así como acontecimientos de orden político, religioso y cultural, llevándolo a ser protagonista de guerras, enfermedades y horrores cometidos contra los demás individuos, todo como resultado de esa "mecánica de poder" predominante en todas las actividades y relaciones humanas.

Esta mecánica del poder la explica Michel Foucault en Vigilar y Castigar al exponer detalladamente la metamorfosis que sufrió "el acto de castigar"(p.10) en contra de aquellos seres humanos que violan la ley. En un comienzo el castigo se realizaba con una fuerte agresión física sobre el cuerpo del infractor, con el fin de ocasionarle lentamente la muerte, lo cual se hacía en un acto ceremonial y público, con el objetivo de generar escarmiento en la sociedad y así mismo demostrar que existía un poder más fuerte que era capaz de castigar y quitar la vida. Este espectáculo grotesco poco a poco fue cambiando, el castigo horroroso sobre el cuerpo fue disminuyendo, o mejor aún, se fue refinando y tecnificando el arte de castigar para pasar a un arte más encaminado a disciplinar, como lo expresa Foucault: 
Disminuir su costo económico y político aumentando su eficacia y multiplicando sus circuitos. En suma, constituir una nueva economía y una nueva tecnología del poder de castigar: tales son, sin duda, las razones de ser esenciales de la reforma penal del siglo XVIII (Foucault, Michel, 2002, p.54)

En esa dinámica, las torturas y las penas de muerte dan vía libre a la aparición de las prisiones, la observación o vigilancia, así como a las disciplinas. Estos nuevos mecanismos de vigilancia y castigo lo que buscan en el fondo es la demostración de poder, el poder de castigar a aquellos que desacatan la norma establecida, solo que ahora se hace de una forma más sutil y logrando la aceptación de una sociedad que legitima el poder de castigar.

Pero este nuevo mecanismo de vigilancia, observación y disciplina no solamente se aplica en la cárcel y como forma de castigo para quienes infringen la ley, pues pasando el tiempo estos mecanismos se van extendiendo a varios sitios en los que se mueven los seres humanos, con el fin de crear cuerpos que operen con técnica, rapidez y eficiencia. De manera que, según Foucault (2002): "la disciplina fabrica así cuerpos sometidos y ejercitados, cuerpos "dóciles"” (p.83).

Es entonces que se aparece un nuevo elemento que favorece el poder y su dominio sobre los individuos y en la sociedad:

\subsubsection{La Disciplina}

Se puede decir que todas las poblaciones a pesar de tener rasgos físicos variados, costumbres y comportamientos distintos, han sido formados con cierta disciplina, que parte desde los hogares como la base de formación de la sociedad y en donde se trata de inculcar principios "positivos", valores y el sentido del respeto hacia sí mismo, hacia el otro y hacia la naturaleza misma. Luego en el colegio como sitio de educación, donde se aprende a través de la disyuntiva entre el castigo y la recompensa. En la fábrica donde se debe regir a un horario y unas labores determinadas a fin de obtener la recompensa de un sueldo, que se reinvierte en lo necesario para vivir. Estos son lugares donde se ejerce un sistema de castigo, control y vigilancia sobre los individuos, que se rige desde el desarrollo del cuerpo formándolo en todo el proceso de crecimiento, moldeándolo hasta tal punto que se ve obligado a realizar diferentes tipos de 
actividades cotidianas, que contribuyen con su formación, lo cual expresa Foucault (2002): "A estos métodos que permiten el control minucioso de las operaciones del cuerpo, que garantizan la sujeción constante de sus fuerzas y les imponen una relación de docilidad-utilidad, es a lo que se puede llamar "disciplinas" (p. 83)

Obtener hombres que sean dóciles, es decir fáciles de conducir, fáciles para dejarse enseñar, ése es el objetivo de las disciplinas. Un ejemplo claro es el soldado, como producto de la implementación de una disciplina, en este caso la disciplina militar: es un hombre con un porte fuerte debido a que ha sido formado y ejercitado con una rutina diaria de ejercicios, con una actitud de valentía frente al peligro, su oficio idóneo es estar siempre listo para el combate, pues para ello se le ha entrenado; debe mantenerse siempre erguido, despierto, alineado y dócil hacia sus superiores, quienes siempre están pendientes evaluando que todos sus movimientos sean coordinados y disciplinados. Este individuo puede ser el ejemplo por excelencia de disciplinamiento:

La disciplina aumenta las fuerzas del cuerpo (en términos económicos de utilidad) y disminuye esas mismas fuerzas (en términos políticos de obediencia). En una palabra: disocia el poder del cuerpo; de una parte, hace de este poder una "aptitud", una "capacidad" que trata de aumentar, y cambia por otra parte la energía, la potencia que de ello podría resultar, y la convierte en una relación de sujeción estricta. (Foucault, Michel, 2002, p.83)

Ya que la disciplina está presente en muchos espacios en la sociedad y se convierte en la principal característica del aprendizaje, se puede decir que la sociedad es una sociedad disciplinaria, como lo indica Foucault (1996):"...yo llamo sociedad disciplinaria por oposición a las sociedades estrictamente penales que conocíamos anteriormente. Es la edad del control social"(p.89). La sociedad disciplinaria, nace en el momento en que los regímenes penales implementaron unas tácticas, unas estrategias en la aplicación de la pena. A finales del siglo XVIII y a comienzos del siglo XIX, el castigo se volvió más sutil y se le dio mayor importancia a la vigilancia y observación de los individuos, a todo lo que realizaban o iban a realizar.

Toda la penalidad del siglo XIX pasa a ser un control, no tanto sobre si lo que hacen los individuos está de acuerdo o no con la ley sino más bien al nivel de lo que pueden hacer, son capaces de hacer, están dispuestos a hacer o están a punto de hacer. (Foucault, Michel, 1996, p.87) 
De esta manera las disciplinas impuestas por la sociedad dominan el cuerpo llevándolo a asumir un determinado comportamiento y encasillándolo de acuerdo a los espacios donde se desenvuelve, dando como resultado un sujeto limitado en su movilidad, vigilado y controlado constantemente y cada vez a mayor escala gracias a la creciente tecnología que lo mantiene conectado a diversas redes que lo comunican con el mundo pero lo alejan de sí mismo, al tiempo que lo encasillan en comportamientos determinados por la tecnología, que a la vez se convierte en una prisión mental que lo hace dependiente de esta a la vez que lo vigila y lo controla constantemente.

Por lo tanto la disciplina se puede considerar como una forma de poder que se practica sobre los cuerpos formándolos por medio de técnicas rigurosas como la vigilancia, la sanción, el examen, que se aplican en varias instituciones en donde se recurre a una gran variedad de discursos que tienen por objeto enseñar a pensar, comportarse, actuar a la persona, de manera que también se puedan moldear ciertos individuos que serán los encargados de aplicar y conjurar los poderes hacía los demás individuos en la sociedad. Sin embargo para Foucault (2002) la disciplina no es de exclusividad de una institución, ni mucho menos de ella misma, es una forma de ejercer poder, por ese motivo la disciplina la ubica dentro de una "anatomía del poder"(p.130). La disciplina entonces forma individuos, los orienta hacia el conocimiento de sí mismo, para luego determinar sus potencialidades y llegar a desenvolverse y ser productivo en determinado medio, que al mismo tiempo se beneficiará de él y sus potencialidades, de tal manera que la disciplina es una expresión del poder, pues determina las actuaciones y relaciones de los individuos al interior del grupo social.

El cuerpo humano entonces en todo momento está involucrado en un sistema disciplinario que se refleja permanentemente en el hogar, en la universidad, un hospital, la prisión o en cualquier lugar donde existan relaciones de poder y sistemas de control; a lo largo de su formación se ve sometido a una especie de laboratorio de poder que lo forma, lo instruye en la casa o en la escuela, lugares donde el individuo es evaluado constantemente, confrontado con las normas que rigen la sociedad y castigado si llega a contrariarlas. Es bajo el castigo que aparece el panóptico como elemento de vigilancia y corrección, desde una disposición de espacio que propicia el control total de los individuos. 
El panóptico era un sitio en forma de anillo en medio del cual había un patio con una torre en el centro. El anillo estaba dividido en pequeñas celdas que daban al interior y al exterior y en cada una de esas pequeñas celdas había, según los objetivos de la institución, un niño aprendiendo a escribir, un obrero trabajando, un prisionero expiando sus culpas, un loco actualizando su locura, etc. En la torre central había un vigilante y como cada celda daba al mismo tiempo al exterior y al interior, la mirada del vigilante podía atravesar toda la celda, en ella no había ningún punto de sombra y por consiguiente, todo lo que el individuo hacía estaba expuesto a la mirada de un vigilante que observaba..."(Foucault Michel, 1996, p.89-90)

El panóptico es un medio específico de las visibilidades que consiste en alinear el espacio arquitectónico de tal modo que los individuos se vean inmersos en una disciplina institucionalizada, regida a una visibilidad total de todos sus movimientos. La prisión lugar de aislamiento y vigilancia para las personas que han cometido una falta contra la ley, es un recinto que reúne todas las características arquitectónicas del sistema panóptico que permiten la observación de los cuerpos, es especial porque tiene la capacidad de que un mínimo de personas ejerzan el poder sobre un número amplio de internos, cuenta con todas las medidas de seguridad para evitar fugas, se apoya en una gran cantidad de sanciones disciplinarias, con un seguimiento del tiempo que obligan a los presos a unas disciplinas diarias como lo es el levantarse a determinada hora, realizar los ejercicios cotidianos, estudiar, trabajar, en fin están pendientes de todos los movimientos de los individuos, ellos son los que se encargan de mantenerlos aislados del espacio moral, psicológico y público.

El cuerpo en la prisión es corregido, o al menos ese es el objetivo formal, el de transformar y encausar a la buena conducta, se le enseña a trabajar, se le educa con el propósito de cambiar su actitud destructora y malévola. Se dice que el objetivo de las instituciones carcelarias en el mundo occidental era tener el pleno dominio del alma y de la conducta.

En la conferencia anterior intenté definir el panoptismo que, en mi opinión, es uno de los rasgos característicos de nuestra sociedad: una forma que se ejerce sobre los individuos a la manera de vigilancia individual y continua, como control de castigo y recompensa y como corrección, es decir, como método de formación y transformación de los individuos en función de ciertas normas. Estos tres aspectos del panoptismo -vigilancia, control y corrección- constituyen una 
dimensión fundamental y característica de las relaciones de poder que existen en nuestra sociedad. (Foucault Michel. 1996, p.107)

Para Michel Foucault el panóptico y la disciplina están relacionados, pues el panóptico está al servicio de la sociedad disciplinaria; en una sociedad donde diariamente se vigila a los individuos con el fin que quien se levante o atente contra el orden implantado en esta, será juzgado, castigado y encerrado en una prisión con el fin de ser educado y corregido. En nuestra cultura los primeros que se encargan de la vigilancia son los padres o cónyuge, luego en la escuela el maestro, en la oficina el jefe, en los hospitales los médicos y enfermeras, en la calle la fuerza pública e infinidad de cámaras de video, en las múltiples instituciones y espacios públicos todo individuo está siendo objeto de una constante observación por cámaras y circuitos cerrados de televisión, que se convierten en los medios que asume el sistema panóptico para un mayor control de los cuerpos. La distribución espacial que existe al interior de un salón de clase, también adopta el sistema panóptico, pues el profesor se encuentra situado en la parte de adelante

y frente a todos los estudiantes, garantizando el control visual de sus aprendices. Así mismo en la iglesia, en la empresa, en la cárcel, etc.

De esta manera la relación cuerpo-poder, es tan intrincada que no permite analizar los elementos por separado, ya que siempre se llega a esta relación, con lo cual se puede llegar a concluir que la construcción del sujeto para Michel Foucault está totalmente atravesada por la disposición del sujeto respecto al poder.

\subsection{El papel de la cultura}

En el tercer apartado de este capítulo se hará un análisis de la cultura y cómo ésta condiciona el comportamiento y actuaciones del individuo.

En todas las culturas es una constante que la educación sea el medio por el cual se transmitan las normas y formas de comportamiento del individuo y la forma de preservar la tradición y las costumbres de la sociedad. Sin embargo la educación ha variado de acuerdo a los diferentes momentos y se ha dado de formas distintas, también teniendo en cuenta la importancia que tenía el niño en la sociedad, así en la edad media era normal que al niño se le separara de su 
núcleo familiar y se le enviara a convivir con un grupo de adultos de quienes aprendería algún oficio y lo necesario para desenvolverse en la vida, lo cual aprendería siendo el ayudante de los mayores, lo que considera Philippe Ariès (1988): "la educación, durante muchos siglos fue obra del aprendizaje" (p.10), y este aprendizaje implica a su vez la transmisión del saber y de los valores, cuya importancia se da en la convivencia del niño con adultos quienes a su vez le enseñan "el tacto («savoir faire») y la cortesía («savoir-vivre»)”(Ariès,1988), lo cual implica que el niño va aprendiendo no solamente un oficio sino una forma de relacionarse, a la vez que no hay una vigilancia de la sexualidad de los niños y jóvenes y la diferencia de edades entre ellos y los adultos.

A finales del siglo XVIII la educación se dio de una nueva forma involucrando la escuela como un nuevo actor en la educación de los niños, separándolos de los adultos y ahora apartándolos para estar con otros de su misma edad en una especie ahora de "cuarentena", en la cual la escuela se encarga de enseñar a los niños todo lo necesario para enfrentarse al mundo de los adultos, pero este periodo llamado escolarización será hasta nuestros días un largo periodo de reclusión de los niños en sitios con la infraestructura necesaria para disciplinar y formar a los infantes en normas que construyan su forma de relacionarse con la sociedad. Esta formación se dio por medio de la disciplina como forma de dominar el cuerpo como lo advierte Michel Foucault (2002): "Podrían encontrarse fácilmente signos de esta gran atención dedicada entonces al cuerpo, al cuerpo que se manipula, al que se da forma, que se educa, que obedece"(p.82), lo cual tiene su sustento en una "reducción materialista del alma", que va a ver el cuerpo como manipulable y formable por medio de una disciplina con el fin de ser "transformado y perfeccionado".

Este modelo de escuela se vio inspirado por el modelo de Universidad de la alta edad media basada en los grados de elemental, secundaria y superior, distanciándose esta de la antigua enseñanza del Salterio, Trivium y Quadrivium, muy marcados en la educación en la alta Edad Media, sin embargo las costumbres y las reglas de convivencia de estas Universidades si se mantenían vigentes al punto que las familias y los educadores llegan a valorar como superiores los colegios con un estricto reglamento y férrea disciplina que les regia, lo cual considera Ariès (1988) que: "un principio esencial en la educación fue en lo sucesivo la sumisión a una regla 
colectiva” (p.231), que va en procura de reglamentar la forma de vida y castigar cualquier trasgresión a la norma con una especie de código penal:

prohibido beber en la taberna y frecuentar los lugares de vicio, prohibido dormir fuera del colegio, armar alboroto, participar en juegos ruidosos, cantar; prohibido introducir mujeres «a no ser que el prior de la casa y los becarios se queden convencidos de que no cabrá ninguna mala sospecha» (Ariès Philippe, 1988, p.231)

Así en todas las escuelas se van dando cada vez de forma más estricta una serie de normas que van regulando las actividades diarias de cada individuo desde el amanecer al anochecer, así como su forma de vestir, su forma de comportarse al tomar los alimentos, hasta la obligación de hablar latín en el momento de consumir los alimentos, de manera que el individuo se acostumbra a vivir de acuerdo a lo que le dice la norma y reduce su iniciativa, de modo que este tipo de vida que en principio rige la convivencia se convertirá en principio rector para determinar la vida moral de los individuos en tanto que les indica lo que es correcto o no hacer.

Este último aspecto fue mucho más identificable a finales del siglo XVI con el auge de los colegios de los jesuitas por la rigurosidad de su disciplina, lo cual los hacía muy aceptados por las familias pertenecientes a la burguesía. Así entonces para Ariès (1988): "se trata tanto de formación como de instrucción; conviene por ello imponer a los niños una estricta disciplina: la disciplina tradicional de los colegios, pero modificada en un sentido más autoritario y más jerárquico"(p.238), esto se da gracias a lo que Foucault plantea en Vigilar y Castigar (2002) como el "rango"(p.89) o disposición de los estudiantes unos al lado de otros, según su eficacia y bajo la mirada atenta y estricta del maestro.

Es también en el siglo XV al XVII que se emplea un método de disciplina humillante: el látigo según la voluntad del maestro, este método inicialmente se aplica a los niños que aprenden a leer y poco a poco se va convirtiendo en una práctica más generalizada con estudiantes cada vez de mayor edad. Este método evidencia según Ariès: "una concepción autoritaria, jerárquica absolutista- de la sociedad", lo cual supone también un apego férreo a la regla de parte del individuo para no ser víctima de la humillación y el escarmiento físico, de manera que queda muy poca libertad de acción para el niño en edad escolar (Ariès, 1988) 
Para Foucault (2002) esta práctica del castigo responde a una “escala de control”(p.83), basada en tratar el cuerpo no como una unidad, sino tratarlo en sus partes con el fin de ejercer sobre él una "coerción débil" que lleve a controlar a su vez los movimientos, gestos, acciones; creando a su vez relaciones de "docilidad-utilidad", de manera que el individuo hace lo que le corresponde hacer y se evita el castigo y a su vez mantiene ocupado de tal forma que su cuerpo se va haciendo útil por medio del ejercicio.

Como si fuera poco este régimen escolar basado en la disciplina, la norma y el castigo; en el siglo XIX, se vio influenciado por la disciplina militar, de manera que según decía Napoleón citado por Ariès (1988): "sin disciplina militar es muy difícil regularizar con exactitud el orden y la disciplina del establecimiento" (p.351).

Las prácticas derivadas de la disciplina utilizada en el ejército, según identifica Foucault (2002): "han circulado a veces muy de prisa y de un punto a otro (entre el ejército y las escuelas técnicas o los colegios y liceos)" (p.84) y básicamente lo que buscan es hacer dócil el cuerpo humano para también hacerlo útil, de manera que cuanto más obediente sea el cuerpo más habilidades puede desarrollar y por consiguiente más productivo será, para lo cual es necesaria la práctica constante del ejercicio para evitar desgaste de partes del cuerpo en actividades menos productivas, ya que un cuerpo ocioso lleva a la mente a divagar y esto necesariamente se considera una actividad nada productiva.

El modelo de escuela que toma fuerza y que se considera más eficaz en la formación disciplinaria del estudiante es el internado, pues se asemeja al convento, en el cual los horarios son estrictos, cada individuo tiene una labor o una responsabilidad en un espacio concreto y también dado que el individuo permanece todo el tiempo encerrado se puede vigilar constantemente su conducta. Este modelo de colegio lo identifica Foucault (2002) como: “insidioso y eficaz"(p.86), porque tiene la posibilidad de instruir a los individuos de forma que no se pierda tiempo a la vez que se puede disciplinar desde el "detalle"(p.97), como la forma de educar desde lo minucioso, es decir estar pendiente de los detalles más mínimos. Esta condición de formación del detalle la considera Foucault como propia de la educación cristiana y de la formación militar con la finalidad de disciplinar la conducta. 
Sin embargo el encierro no solamente es utilizado como forma de dominación en la educación, ya que también se utilizó desde mediados del siglo XVII como tratamiento para los insensatos, lo cual hace ver Foucault (1998) en Historia de la Locura en la Época Clásica: "Desde la mitad del siglo XVII, la locura ha estado ligada a la tierra de los internados, y al ademán que indicaba que era aquel su sitio natural" (p.38), al mismo tiempo que los mismos hospicios donde se encerraba al loco también era el sitio de encierro para vagos, desempleados, mendigos y demás pobres que para evitar que deambularan por la ciudad se les encerraba con el propósito de ayudarles en un sitio donde se les mantuviera controlados, a la vez que se les podía reprimir por medio del trabajo y los castigos, lo cual identifica Foucault (1998): "El internamiento queda así doblemente justificado en un equívoco indisoluble, a título de beneficio y a título de castigo. Es al mismo tiempo recompensa y castigo" (p.47). De esta manera el encierro se puede interpretar como la condición correcta para lograr un orden social ideal donde quienes se salgan de la norma y la condición establecida, deben estar recluidos en lugares donde por medio del castigo y la disciplina, a través del trabajo puedan ser moralmente aceptados en la sociedad productiva.

Por lo tanto la escuela se convierte en la forma que utiliza la sociedad, la religión, la cultura, la tradición y el Estado para moralizar los comportamientos de los hombres desde temprana edad, de esta manera la educación se convierte en represión y mecanismo de control del individuo, de tal forma que las normas del colegio se van convirtiendo poco a poco en normas morales para los hombres, y cualquier falta a estas normas aprendidas en la infancia se convertirá en transgresión a la norma y a la moral de la sociedad.

Estas normas se van a replicar en la fábrica y en el taller, sitios en los cuales los hombres también están en continua vigilancia de parte de un guarda o supervisor, el primero que se encarga de cerrar las puertas y controlar los tiempos de los trabajadores y el segundo que se encarga de vigilar la calidad del trabajo y que el obrero no esté perdiendo tiempo. Para Michel Foucault (2002), la fábrica sigue el mismo modelo del convento y la fortaleza con el fin de conseguir el máximo de productividad: "Se trata, a medida que se concentran las fuerzas de producción, de obtener de ellas el máximo de ventajas y de neutralizar sus inconvenientes...; de proteger los materiales y útiles y de dominar las fuerzas de trabajo" (p.86) 
Estas normas morales no solamente se evidencian en la vida escolar de los niños, sino también en la forma de relación con su entorno en la vida adulta, de manera que estas normas aprendidas en la infancia van trazando una frontera entre la vida pública y la vida privada y es en este ámbito que se da una inmensa diferencia entre hombres y mujeres, su valoración, su forma de ver la familia y la forma como ellos se manifiestan en la vida pública y las mujeres en la vida privada o en la vida doméstica, es decir al interior de la familia como esfera de lo privado para el individuo, y es allí al interior de la familia, según el modelo inglés victoriano, analizado por Ariès y Duby en la Historia de la vida privada (2001), que la mujer primero en las clases medias y luego en las clases obreras fue moralizando con las virtudes de buena ama de casa, lo cual se va difundiendo poco a poco desde las clases dominantes y luego se buscará sea el modelo a seguir en las clases obreras.

Así la familia se fortalece como célula de base de la sociedad civil, pues es en ella donde se administran los intereses privados, es decir donde se administran los recursos materiales que pasan a manos de los hijos como intereses patrimoniales; es en la familia donde se garantiza la reproducción, la continuidad de la especie y la salud de esta, lo cual se da desde el lecho matrimonial como garantía de unos hijos sanos moral y físicamente; es la familia la transmisora de los valores y principios de la persona, tarea de la se encarga totalmente la madre; la educación de los hijos y la formación para el futuro; la familia es el germen del amor maternal y del amor patrio, que puede llegar a complementarse pues la madre da la vida biológica y la patria da la ciudadanía, como la vida política.

En la familia también se da un aspecto bien importante que es la educación de los hijos e hijas, desde la visión del padre como figura clave de la familia, de manera que el niño va a ser visto como el continuador de la familia y quien da el nombre a sus hijos lo cual supone el verdadero alumbramiento. Así su educación va a darse no desde el individuo, sino desde lo que denominan Ariès \& Duby (2001): "hijo como "ser social"” (p.151), pues es la imagen proyectada y soñada de su padre. Mientras tanto la niña no se educa al mismo ritmo que el niño, sobre todo en lo concerniente a la escolaridad, pues quien la educa inicialmente es la madre y si es la hija mayor su principal papel será la de suplirla cuando ésta no esté. También la educa en los quehaceres domésticos y en el comportamiento, como continuidad del propio comportamiento de 
la madre. Más adelante será el confesor el segundo responsable de la formación de la niña, esta vez en la formación moral y religiosa. Así la madre se encarga de iniciar la niña en las labores del hogar, que a la vez será todo su contexto y el confesor se encarga de la formación moral.

Por otra parte la familia se va convirtiendo también en terreno de lo público pues el Estado fue entrando en la vida familiar en forma de legislación sobre el matrimonio, la educación de los hijos, el divorcio, etc. De manera que en el momento de la revolución francesa según Ariès \& Duby (2001): "la vida privada parecía finalizar con la Revolución y sólo comenzaba de nuevo al abandonarse la vida pública"(p.42), sin embargo consideran estos autores que con la literatura del marqués de Sade se explora la sexualidad que se podría considerar como lo más profundo de la vida privada y Sade lo representa como una cárcel a la cual es difícil penetrar y una vez al interior de ella para llegar al placer es necesaria la crueldad y se hace necesario el asesinato. (Ariès y Duby, 2001)

Es al interior de este espacio de encerramiento y prisión que aparecen las mujeres como objetos de placer, pues ellas no son libres ni sienten placer por voluntad propia, sino al contrario como lo expresan Ariès \& Duby (2001): "las mujeres son el objeto de la agresión masculina, y no tienen prácticamente identidad física" (p.48), convirtiéndolas en el instrumento para la expresión del despotismo y fuerza de los hombres y aunque la obra de Sade no se puede ver como la expresión total de la sexualidad durante la Revolución, si puede dar una idea de cómo la mujer solo tiene validez en el ámbito privado y como se le utiliza como un instrumento para el disfrute sexual del hombre, además de hacer ver la mujer como sujeto de tortura y de crueldad, ya que ella no debe hacer público nada de lo que pase con su cuerpo ni mucho menos con su sexualidad pues es parte de lo privado y de lo escondido en la familia, de lo contrario no solamente se deshonra ella, sino la familia misma.

Así entonces en el contexto de la Revolución se puede ver que los hombres solo vieron a las mujeres como madres o hermanas, cuya identidad dependía solamente de su relación o parentesco con los hombres. Cualquier otra relación fuera de estas se originaba desde el convertir a las mujeres en mero objeto sexual. 
Sin embargo esta forma de ver a la mujer solo para el contexto de lo privado, no fue exclusivo de la Francia revolucionaria, ya que es frecuente que esto se repita en la mayoría de sociedades del siglo XIX, como lo advierten Ariès y Duby (2001) al citar El tratado de Pierre Roussel Du système moral et physique de la femme (1775), de donde se desprende que la mujer se considera como el reverso del hombre y solo se le llega a identificar por su sexualidad y su cuerpo, mientras al hombre se le identifica por su mente y su energía, de manera que la mujer solamente tiene sentido en cuanto a su función sexual de satisfacer los deseos sexuales del hombre y su función de madre, lo cual se determinaba por su útero, que a la vez determinaba el comportamiento y su actuar moral, pues se considera que la contextura física de la mujer es mucho más débil que la del hombre y a la vez mucho más sensible de manera que se debe controlar y cuidar esta sensibilidad proveniente del físico débil de la mujer, lo que la hacía apropiada para mantenerse sedentaria en la casa cuidando la familia, criando los hijos y atendiendo suaves tareas domésticas al tiempo que estaba encerrada en casa y ese era su papel en la sociedad.

En palabras de Ariès y Duby (2001): “Así, el útero definía el lugar que correspondía a las mujeres en la sociedad, es decir, el de madre. Las disertaciones de los médicos llegaban a las mismas conclusiones que las de los políticos" (p.49), por lo tanto el sujeto de derechos de las mujeres solamente se encontraba supeditado al papel de la mujer en la sociedad que a la vez se basaba en su función dentro de ella: ser madre y criar los hijos, lo cual las convertía en seres frágiles que debían ser protegidos del mundo exterior asociado a lo público, convirtiendo así a las mujeres en símbolo de lo privado como una cuestión frágil que era necesario alejar de lo público y encerrar en lo privado. Sin embargo el Estado también entra mediante la legislación en la familia que es espacio privado, por lo tanto aunque las mujeres se encuentran confinadas a este espacio no son dueñas y señoras de este.

Señalan Ariès y Duby (2001) sobre este mismo aspecto, la convicción de los evangélicos del siglo XVIII (movimiento reformista, surgido en el seno de la Iglesia anglicana, que comenzó a ganar poder e influencia a partir de finales de 1770$)^{23}$, sobre la igualdad de hombres y

\footnotetext{
${ }^{23}$ Ariès P. \& Duby, G. (2001). Historia de la vida privada, V.4: De la revolución francesa a la primera guerra mundial. Madrid: Taurus. pg.57
} 
mujeres, como "inmoral y contra natura” (p.57), pues la estructura biológica de hombres y mujeres los lleva a realizar diferentes tareas y los lleva a buscar su "destino como personas", de manera que al realizar las mujeres tareas de hombres estarían negando la fisionomía que Dios les ha dado para hacer ciertas tareas. Así mismo los evangélicos del siglo XVIII; creían que hay igualdad entre los seres humanos en cuanto a la salvación para todos sin importar su sexo, pero esta igualdad no aplica en lo social ya que "el "círculo menor" abarcado por la mujer, venía a querer decir que, en el aspecto social, ésta estaba subordinada a su marido" (Ariès y Duby, 2001), lo cual sustentan en la cita de san Pablo: "esposas, someteos a vuestros maridos, como Dios lo ordena”, entrando aquí otro aspecto en cuanto a la diferencia entre hombres y mujeres: la espiritualidad, que va a ser más propia de la mujer que del hombre, ya que ella al estar en el hogar puede dedicarse más a las tareas propias del plano religioso y espiritual, mientras que el hombre que está en el trajín diario y bullicioso del día a día no lo puede hacer de la misma manera.

Es entonces que se hace evidente que la religión tiene una clara y fuerte influencia desde sus creencias en cultivar la diferencia de los hombres y las mujeres de acuerdo a sus tareas, a la contextura física de unos y otras y consecuente subyugación de la mujer al hombre porque viene de un designio divino.

Desde la filosofía, Ariès y Duby (2001) citan a Hegel que analiza como la familia se puede considerar el fundamento de la sociedad civil en los Principios de la filosofía del Derecho (1821), abordándolo desde la relación entre el individuo, la sociedad civil y el Estado, equilibrio que se da desde la familia como la garantía de moralidad natural, siempre basada en el matrimonio monógamo y según Hegel el mejor matrimonio no es el que se da desde las pasiones y los sentimientos, sino el matrimonio arreglado que garantiza una organización social pensada con anterioridad, lo cual hace que la familia sea un "ser moral: "una sola persona cuyos miembros son accidentes"' (p.98), de tal manera que la familia es un todo superior a sus partes y los individuos deben someterse a ella teniendo en cuenta que el padre es el jefe de la familia. Por lo tanto Hegel no se distancia en mucho de la visión de la familia y de la mujer de la sociedad de su tiempo, puesto que considera a la familia como la base de la sociedad, pero esta familia tiene un jefe que es el padre, y todo en esta debe estar subordinado al padre. 
Ariès y Duby (2001), citan también a Kant, quien por su parte fija su atención en el espacio de la casa y no se centra como lo hace Hegel en considerar la articulación de lo público y lo privado. Así entonces para Kant, citado por Ariès y Duby (2001): “el derecho doméstico es el triunfo de la razón" (p.99), pues considera que es en la casa, en lo privado y particular de cada quien donde se origina la moral y el orden. Sin embargo Kant, citado nuevamente por Ariès y Duby (2001) también considera que la casa debe estar sometida al padre porque: "es el único capaz de domesticar los instintos, de someter a la mujer" (p.99), para Kant la mujer se convierte en una dualidad, pues se considera el centro de la casa, pero también en una amenaza porque no es capaz de llevar las riendas del hogar sin la dirección del marido, por eso el padre es la cabeza aunque no sea el centro de la casa y la mujer debe estar sometida a su marido para garantizar el orden de la casa.

En el análisis de esta constante de desigualdad entre el hombre y la mujer, se encuentra entonces el escenario donde esta desigualdad se vive a diario y en cada uno de los aconteceres esta se evidencia: encontramos entonces el matrimonio donde la vida de pareja y la sexualidad tiene su espacio adecuado donde desarrollarse, pero a la vez es el espacio en el cual la sexualidad evidencia más el dominio del hombre sobre la mujer, esto lo muestran Ariès y Duby (2001) al enunciar: "La virilidad está amasada de proezas fálicas, ejercidas con toda libertad sobre las mujeres y sobre todo sobre las hijas"(p.271), de manera que en lo privado (familia) el padre domina la sexualidad no solamente de su pareja, sino también de las hijas y esto como manifestación de la superioridad desarrollada en la sociedad, por parte del hombre. Pero la sexualidad femenina no solamente se ve dominada por el padre, sino también por la Iglesia que impone el modelo mariano a toda la sociedad y se vale de una serie de prácticas para salvaguardar la virginidad de las jóvenes y mantener en ellas la virtud. Estas prácticas involucran una serie de prohibiciones a las jóvenes que van desde la prohibición de salir solas a lugares públicos, prohibición de salir a bailes, a los que van frecuentemente acompañadas de padres y hermanos y recomendaciones de los confesores para ser una joven virtuosa y comportarse considerando rigurosamente ciertas normas, para ser vista de esta manera.

Sin embargo la desigualdad de hombres y mujeres en el hogar se hace evidente de una forma aún más cierta: la infidelidad de parte de alguno de los cónyuges, entonces si esta 
infidelidad se presenta de parte del marido, la sociedad lo tolera y hasta se convierte en una forma de expresión de la virilidad y de masculinidad, mucho más si hay hijos fruto de dicha infidelidad. Para el hombre la infidelidad es simplemente la reafirmación de su masculinidad y de su dominación sobre la mujer. Mientras que la infidelidad de parte de la mujer hasta el siglo XIX, según Ariès y Duby (2001): se consideraba "el mal absoluto contra el que el marido tiene todos los derechos" (p.272), hoy aunque la legislación no es tan dura en cuanto al adulterio femenino, el reproche de parte de la sociedad e incluso de los hijos es aún bastante evidente.

Teniendo en cuenta esta situación de opresión en la vida familiar hacia la mujer, se puede decir que la infidelidad femenina es simplemente un reclamo por salir del encierro de su casa y los deberes del hogar por varios siglos, es entonces un reclamo de libertad y de igualdad frente al marido opresor.

Dando un paso más en esta indagación de la forma como la cultura va configurando los comportamientos sexuales teniendo en cuenta el sexo, la edad y la condición social, se encuentran otros dos elementos que enuncian Ariès y Duby (2001): los espacios privados y el vestido. En cuanto a los espacios privados, las familias van considerando espacios para cada ocasión, esto iniciando con las familias acomodadas que gozan de inmuebles grandes en los cuales se pueden dar los espacios para cada necesidad en la cotidianidad, pero el espacio más importante en los inmuebles para la familia, será la alcoba conyugal como la "especialización de un recinto sagrado", provisto de un lecho nupcial y destinado a la intimidad de la pareja. Esta alcoba y en especial este lecho se convierten en la expresión de la sexualidad de la mujer ya que desde niña es tarea de la madre y de las demás mujeres de la familia ir aprovisionando de la lencería, y la ropas de la casa para el matrimonio de la joven, estas irían marcadas con sus iniciales y serían solamente de su propiedad, es decir no se puede heredar de madre a hija o de una hermana mayor a otra menor.

En cuanto al vestido la prioridad al parecer es ocultar la desnudez de la mujer con una serie de prendas domesticas para cada momento del día y de la noche, entre las que aparece el camisón conyugal como parte del ajuar de la mujer y que no permite que ni siquiera su amante le vea desnuda. Se incluye también una "toilette" que será la prenda que la mujer utilice en la 
mañana para estar en la casa, sin embargo esta prenda no es apropiada para estar en todos los espacios de la casa ya que la mujer que se presente "destocada" en los espacios públicos de la casa, sería como la forma de presentarse de la sirvienta o la prostituta, por tanto la forma de vestir y en lo posible lo más cubierta que se pueda presentar será lo que designe la integridad de la mujer. Un segundo aspecto importante en cuanto al vestido, mencionado por Ariès y Duby (2001) es: "el auge inaudito de las prendas íntimas" (p.421) que le da más misterio a la desnudez, sobre todo a la desnudez de la mujer, impregnándole cada vez más sensualidad a estas prendas con el empleo de encajes y bordados. Ejemplo de estas prendas, según enuncian Ariès y Duby (2001) es: "El calzón. Usado al principio sólo por las niñas, se impone entre las mujeres... su uso se ha vuelto imperativo, al menos en la burguesía" (p.421). Pero esta prenda no es la única prenda íntima que debe usar la mujer ya que es imprescindible el uso del corsé cada vez más lleno de nudos, broches y botones. Estas dos prendas se convierten en símbolo de la intimidad femenina y en algunos casos objetos de deseo y hasta de fetichismo, lo cual también evidencia que el vestido femenino es expresión de dominio sobre su cuerpo pues cada vez se van colocando más prendas, más pesadas e incomodas sobre el cuerpo femenino haciéndolo sentir como prisionero y espacio de sexualidad solamente visto por el marido.

Por lo tanto es evidente que el cuerpo femenino es objeto para esconder de lo público y es propiedad del marido quien solamente puede verlo parcialmente desnudo, de manera que el vestido se convierte en una cárcel para la mujer, pues debe cada vez debe soportar sobre su cuerpo prendas más pesadas y estilizadas que resaltan la sensualidad, pero no para su comodidad, ni teniendo en cuenta su físico. Por otra parte el espacio de la casa, los oficios propios de la mujer y el mismo vestido le impiden relacionarse con la esfera de lo público, a la que accederá solamente por medio del marido, tanto física como socialmente, dando espacio entonces al chisme y al rumor como ventana de la mujer hacía lo público.

\section{****}

Todas estas costumbres son propias del contexto de la revolución francesa y en Inglaterra en la era Victoriana, sin embargo en Latinoamérica no somos ajenos a estas costumbres y mientras en Europa se vivían las tradiciones enunciadas anteriormente, en América se vivía la 
colonia y por lo tanto se manifestaban costumbres como estas aunque en un contexto regional, todas ellas heredadas de Europa y llegadas a América a través de la tradición portuguesa y española predominantemente.

En este apartado se profundizará sobre el matrimonio en la época colonial y como este es el reflejo de la teoría occidental en cuanto a la sexualidad. Según Jaime Borja y Pablo Rodríguez (2011): "uno de los hechos memorables de la historia de la sexualidad occidental ha sido la persistencia del matrimonio monogámico, restringido" (p.197), por lo tanto el matrimonio en Latinoamérica también es la institución aceptada moralmente para vivir los sentimientos y el amor de una pareja conformada solamente por hombre y mujer y para garantizar el ejercicio de la sexualidad con la finalidad de la reproducción. Esta unión matrimonial fue limitada por parte de la Iglesia con normas precisas en cuanto a la expresión del amor en la unión matrimonial. No obstante para llegar al matrimonio también se debían cumplir con ciertas costumbres propias de la época colonial, una de ellas era la dote, que la define el profesor Jorge Gamboa (2003): "una entrega de bienes...que hace la familia de la mujer... al futuro marido o a sus parientes" (p.14), estos bienes podían incluir dinero, tierras, ganado, mercancías, joyas, incluso esclavos y lo más importante el ajuar de la novia, la ropa de casa y la lencería, es decir lo necesario para comenzar un nuevo hogar, pero este ajuar sobre todos los demás bienes de la dote, guarda un contenido bastante sexual y lo identifica Gamboa (2003) como "la identidad femenina", pues se convertirá en parte esencial de la alcoba y el lecho matrimonial donde se ejercerá la sexualidad de la pareja, con lo cual a la mujer se le recuerda su función en la sociedad de ser madre y esposa.

Este es el precio que debían pagar las mujeres por contraer matrimonio, sobre todo las mujeres de clase más alta en la colonia, sin embargo los hombres también dan a la mujer un dinero al que llaman "arras" que cumple dos funciones: es la garantía que la unión se llevará a cabo y es una especie de compensación que da el marido a su esposa por la pureza o virginidad perdida en la noche de bodas, esta suma de dinero era consignado en el recibo de la dote. Por lo tanto se puede decir que llegar al matrimonio tenía un costo tanto para hombres como para las mujeres, teniendo en cuenta que para ellas y sus familias implicaba el ahorro de muchos años para que la mujer pudiera llegar al matrimonio y se pudiera establecer dentro de lo que se consideraría el orden social y religioso establecido. 
Teniendo en cuenta este aspecto es importante citar las funciones que según el profesor Gamboa (2003), se le da a la dote: “-Proporcionar a la pareja los medios para establecer un nuevo hogar, -Asegurar el futuro de una mujer y sus hijos en caso de viudez. -Facilitar la realización de un matrimonio ventajoso para la mujer y su familia" (p.27)

Así entonces la dote no es solamente el precio que debe pagar la mujer para llegar al matrimonio sino que también es la forma como la familia procura casar bien a la mujer con el fin de darle un lugar en la sociedad. Sin embargo señala también Gamboa (2003): "la dote en Roma surgió con el objeto de compensar la pérdida de los derechos patrimoniales que sufría la mujer como consecuencia de la ruptura de todo vínculo con la familia paterna” (p.71), por lo tanto se entiende que la mujer perdía derecho a herencia y además debía pasar a la supervisión del marido quien de ahora en adelante se encarga de administrar los bienes de la mujer, por creerla en incapacidad de administrarlos, sin embargo estos bienes dados en la dote volverían a la mujer en algunos casos como la viudez, sin embargo en muchas ocasiones estos bienes pasaron inmediatamente a manos de los hijos quienes se encargaban de administrarlos, por tanto la dote dejaba de ser de la mujer y de su familia para pasar a manos de un hombre, considerando de nuevo la minoría y la incapacidad de la mujer de administrar sus propios bienes.

En síntesis la dote sirvió según las autoridades coloniales, citado en el texto de Gamboa (2003) para: "ayudar a las cargas del matrimonio" (p.98), permitir que las mujeres tuvieran acceso al matrimonio y lograr una buena posición social, lo cual demuestra que la mujer se considera inferior para administrar y es necesario que un hombre la mantenga bajo su tutela y protección y por último se exterioriza el interés económico de parte del hombre y de su familia. Esto se hace tan evidente que proporcionar la dote a las mujeres que no tenían medios para llegar al matrimonio se convierte en obligación de familiares cercanos, la comunidad y por último el Estado, con el fin que estas mujeres no quedaran desprotegidas al no poder casarse o cayeran en la prostitución que sería el único camino que podrían tomar, ya que ingresar al convento también requería de la dote.

En cuanto a las viudas, no pueden disponer de la dote una vez fallecido el marido, ya que esta pasa a manos del hijo mayor quien la administra y al morir la viuda, la dote queda a 
disposición de los hijos como parte de su patrimonio por herencia. De esta manera se evidencia que la dote es un beneficio para el marido y luego para los hijos, pues la mujer en ningún caso la administra ni dispone de ella después del matrimonio.

De acuerdo a los aspectos analizados anteriormente, se puede concluir que la educación, la religión y la cultura han sido elementos determinantes en el dominio que la sociedad ejerce sobre los individuos, convirtiéndolos en sujetos sometidos a la ley que puede entrar en cualquier aspecto de la vida del individuo, sometidos a la educación que le determinará las formas de comportamiento y dará desde el colegio las normas para vivir en sociedad, sometidos a la religión que desde la creencia de occidente se basa en el dominio del cuerpo y de todas las formas de expresión de la sexualidad; aspecto que solamente quedará confinado al matrimonio como institución encargada de velar por la familia, las buenas costumbres y la vivencia de valores cristianos al interior de la sociedad. 


\section{CAPITULO III}

\section{LA REPRESION DEL CUERPO Y LA SOCIEDAD CONTEMPORANEA}

\subsection{Represión del cuerpo desde la visión de Michel Foucault}

De acuerdo a lo que se ha visto en esta investigación el cuerpo ha sido el espacio donde convergen la religión, las costumbres, la cultura, la educación, todas como expresiones de poder; así que dando un paso más en la presente investigación se profundiza en este capítulo sobre la visión del cuerpo y la represión mental que sobre él se ejerce desde la medicina y el nacimiento de la clínica, que tendrán como finalidad calmar el cuerpo de tal manera que este no sea manifestado sino acallado, aplacado y tranquilizado. Lo cual inicia Michel Foucault describiendo desde la medicina clasificadora: cómo el cuerpo se vuelve objeto de discurso desde el lenguaje de la medicina, pero en sí es un objeto mudo que solamente se presta para ser observado y analizado por un sujeto que lo observa y lo hace objeto de análisis, con el fin de suministrar un tratamiento que tenga como finalidad el tratar la enfermedad, y es esta, la noción que atraerá toda la atención de la medicina de manera que importa la enfermedad mucho más que el cuerpo y este solamente se verá como el espacio en el cual se desarrolla la enfermedad con todos sus síntomas.

La primera característica que describe Foucault sobre el cuerpo es que se convierte en elemento de discurso, en el cual el lenguaje también entra a jugar un papel importante pues la palabra tiene el poder de simbolizar algo, mostrar y a la vez ocultar; simbolizar cuando por definición busca mostrar lo que otros han dicho anteriormente, de tal forma que se convierte en algo análogo a la realidad que está buscando interpretar y significar.

Una segunda característica del cuerpo es el espacio en el cual se desarrolla la enfermedad, es un espacio sólido y visible que permitirá la observación, el análisis y el determinar según el cuerpo los espacios y los órganos en los cuales se desarrolla la enfermedad, a la vez que permite determinar el desgaste y los cambios que va provocando la enfermedad en cada uno de los órganos, de tal manera que la medicina entra a observar, estudiar, clasificar y medicar teniendo en cuenta el cuerpo solamente como un espacio que se debe tener en cuenta para comprender la enfermedad. 
Pero para este fin entonces es necesario conocer lo que llama Foucault (2004): "la estructura interna de nuestros cuerpos" (p.23), de manera que se puedan identificar con certeza los síntomas y demás circunstancias propias de la enfermedad, que a su vez exige que el médico le conozca bien con el fin de curar al enfermo y el éxito de esa curación depende solamente del conocimiento que tenga el médico tanto de la enfermedad como de los síntomas que va dejando ésta en el cuerpo, así entonces lo importante para el médico es la enfermedad, su exploración, su avance, por lo tanto para el médico en un primer momento no es importante detener la enfermedad, sino mirar lo que ella ocasiona en el cuerpo y si esta es demasiado violenta en cuanto a los dolores y las molestias, lo único que debe hacer el médico es buscar disminuir estos síntomas, más no acabar con la enfermedad.

De esta manera como lo que importa es el espacio de la enfermedad, los sujetos médico y enfermo pasan a un segundo plano, pues su única relación es la enfermedad, y la mirada que el médico pueda hacer de ella en el cuerpo del enfermo, que solamente vale en cuanto es el espacio donde se manifiestan los síntomas y se devela la enfermedad, espacio, que a la vez se vuelve valioso pues no en todos los cuerpos la misma enfermedad se manifiesta de la misma manera y los síntomas se desarrollan de manera distinta en cada cuerpo, lo que define Foucault (2004) como: "la esencia de la enfermedad, con su estructura en cuadro, se articula en el volumen espeso y denso del organismo y toma cuerpo en él” (p.26). Incluso en cuanto a los órganos, el interés de la medicina clasificadora no es describir el órgano en sí sino los cambios y daños que hace en él la enfermedad.

Desde la medicina de las especies se entiende que la enfermedad se desarrolla sola y ajena a los espacios de las sociedades, pero en cuanto más se desarrollan las sociedades, los estragos que pueden hacer las enfermedades pueden ser cada vez mayores, de manera que en la familia que es el mismo espacio en el que inicia la vida también inicia la enfermedad, y es aquí mismo donde se engendran las epidemias, pues solamente con que una enfermedad se repita en varios individuos se puede hablar entonces de epidemia. El análisis que se hace de la epidemia no tiene como completa finalidad analizar la enfermedad, sino las circunstancias que la rodean, el espacio y el tiempo en el cual aparece la epidemia y el factor común de los enfermos para poder entender entonces las circunstancias que la causan, así como las condiciones de contagio, una de ellas 
puede ser de forma viral lo cual involucra muchos individuos que en el estudio de la medicina no importan como seres humanos, sino como cifras de conteo de la epidemia ante la cual se prenden las alertas en los sitios donde convivan gran cantidad de personas y es responsabilidad del delegado, el alcalde, el jefe reportar al médico, los casos de la enfermedad en el grupo a su cargo.

Esto constituye una actividad de vigilancia constante sobre los grupos humanos y una serie de prácticas que garanticen la no propagación de la enfermedad a gran cantidad de la población:

No habría medicina de las epidemias, sino reforzada por una policía: vigilar el emplazamiento de las minas y de los cementerios, obtener lo más rápidamente posible la incineración de los cadáveres en vez de su inhumación, controlar el comercio del pan, del vino de la carne, reglamentar los mataderos, las tintorerías, prohibir los alojamientos insalubres.(Foucault, 2004, p.47)

Estas son algunas de las actividades de prevención del contagio de las epidemias, todo bajo la supervisión constante del Estado, que a su vez debe constituir un estatuto político de medicina con el fin de prevenir y controlar las enfermedades que pueden afectar a gran parte de la población.

Todo esto se basa en las circunstancias, en el análisis del tiempo y el espacio, lo cual constituye el principal interés de la medicina del siglo XVIII, más que en la mirada atenta del individuo como sujeto en quien se desarrolla la enfermedad y quien debe ser curado y atendido.

Es entonces cuando se está frente a la medicina clasificadora cuya tarea es recopilar el mayor número de datos posibles en cuanto al desarrollo de las enfermedades de la población, así como buscar señales y síntomas de enfermedades en cualquier espacio y práctica humana con el fin de prevenir, pero en ningún momento se hace un análisis del enfermo como individuo y desde su singularidad, al contrario lo ve solamente como un contagiado más; este hecho también determina la forma como el médico y el enfermo se relacionan de una forma totalmente aislada el uno del otro pues para el médico lo importante no es el individuo-enfermo como sujeto, sino como portador de la enfermedad, el médico además se debe ocupar de vigilar la conducta del enfermo para llegar a encontrar en él las causas de la enfermedad. Esta actitud de vigilancia se 
hace una constante en la medicina del siglo XVIII, pues los médicos se dedican con gran entusiasmo a la estadística de nacimientos y decesos, así como las enfermedades que causaron las muertes, todo esto con el fin de llevar en cada provincia un registro y control de las enfermedades, las costumbres y prácticas de la población y como estas se convierten en foco de enfermedad.

Y en este mismo aspecto la tarea de los médicos se transforma en educación pues la mejor forma de prevenir la enfermedad es educar a la población sobre corregir ciertas prácticas que no favorecen salubremente y adquirir otras que mejoran el estado de salud de los individuos y previenen el contagio de enfermedades.

Así entonces identifica Foucault que son dos los actores dentro de la sociedad que se encargan del cuidado y atención de los hombres: los sacerdotes que se encargan de la consolación de las almas y los médicos que se encargan del alivio de los sufrimientos, con lo cual se sustituyen las dos tareas primordiales de la Iglesia, ante lo cual se advierte que el Estado debe velar porque hayan los recursos para que se cumpla esta doble misión de parte de los sacerdotes en cada parroquia y de los médicos en cada región y población (Foucault, 2004).

Por otra parte señala Foucault (2004): "la primera tarea del médico es, por consiguiente, política: la lucha contra la enfermedad debe comenzar por una guerra contra los malos gobiernos: el hombre no estará total y definitivamente curado más que si primeramente es liberado"(p.59), de esta manera el objetivo de la medicina de ser simplemente vigilante de la enfermedad, cambia a una mirada hacia las condiciones en las que se desenvuelve el individuo y sus necesidades básicas, de manera que la falencia en la satisfacción de necesidades se deriva del mal gobierno y la negativa de atender de forma prioritaria a la población; si estas necesidades son completamente cubiertas por el Estado entonces la medicina no tiene ya necesidad de curar, sino solamente de prevenir y enseñar a la juventud como mantener una vida con salud. Así con ausencia de enfermedad entonces la visión del hombre también cambia y ya no se le verá como el espacio donde se desarrolla la enfermedad sino como un hombre sano en completa armonía con la sociedad, de manera que la medicina se define, en palabras de Foucault (2004): “Al fin, la medicina será lo que debe ser, el conocimiento del hombre natural y social" (p.61). 
Pero este hombre debe preservarse de la enfermedad fruto de las malas prácticas, y es allí donde la medicina tiene otra tarea: la de proteger a los enfermos unos de otros y es allí cuando se crean clínicas especializadas en ciertas enfermedades con el fin de confinar los enfermos de acuerdo a su dolencia y alejarlos de la sociedad, con el fin de preservar esta de la enfermedad y atender a los enfermos de acuerdo a su dolencia, de tal forma que vuelve a comenzar la observación de la enfermedad por encima del enfermo, pues se requiere conocimiento avanzado de la enfermedad para tratarla. De nuevo entonces el enfermo es tratado como un caso, pero como persona es indiferente pues su cuerpo es como un documento donde se lee la verdad que la enfermedad revela a través de los síntomas.

El conocimiento analítico y total de la enfermedad plantea para la medicina que debe preocuparse por la formación más a fondo y a conciencia de los médicos y de los hospitales como el espacio de conocimiento de la enfermedad, de manera que la formación médica es el medio para sacar a la luz la enfermedad y hacerla visible a través de su conocimiento. Esto supone que se deba hacer investigación, que acorde al modelo investigativo del momento, plantea Foucault (2004) es el: "modelo epistemológico de las matemáticas"(p.152), lo cual supone que el estudio médico se haga, según Foucault (2004): "Por este método, se descompone, se hace la disección de un sujeto, de una idea compuesta; se examinan separadamente las partes unas después de otras; las más esenciales primero, luego aquellas que lo son menos, con sus diversas relaciones; se lo eleva a la idea más simple”(p.152), método que supone utilizar la inducción como forma de ir de lo conocido a lo desconocido, de manera que la misma enfermedad en un momento desconocida, se da a ver en los síntomas conocidos, que se evidencian en el cuerpo del enfermo.

La formación de los médicos debe hacer más énfasis en la observación y de nuevo el interés por el enfermo, como la forma de descubrir las señales que va dando la enfermedad. Plantea Foucault el ejemplo de la clínica de Edimburgo, donde la observación se hace teniendo en cuenta cuatro cuestiones: $1^{\circ}$ : edad, sexo, temperamento y profesión del enfermo; $2^{\circ}$ : síntomas que sentía; $3^{\circ}$ : origen y desarrollo de la enfermedad; $4^{\circ}$ : causas lejanas y accidentes anteriores. (Foucault, 2004). Contrapone Foucault la clínica de Montpellier, donde se da otra forma de observación basada en distinguir primero las alteraciones que se van dando en el cuerpo y segundo en observar las materias excretadas, para por último llegar a observar los cambios en las 
funciones de los órganos (Foucault, 2004). De manera que se encuentra un cambio en la forma como se entiende el cuerpo del individuo para ahora tener en cuenta su historia, su ocupación y su forma de vida, como elementos a tener en cuenta en el momento de observar la enfermedad; sin embargo el interés que se tiene por el individuo lo sigue determinando la enfermedad, la observación de sus síntomas y su desarrollo.

El siguiente aspecto que analiza Foucault en cuanto al estudio de la enfermedad y el cuerpo humano tiene que ver con la posibilidad de realizar autopsias sobre cadáveres con el objetivo de investigar y observar en ellos, esta práctica según describe Foucault se hace común en hospitales y escuelas de medicina a mediados del siglo XVIII, momento en el que no hay objeciones de parte de la Iglesia y la moral para tal práctica. La intención de abrir cadáveres no es otra que la de conocer el cuerpo muerto para ayudar al vivo, lo cual se desarrollará desde una medicina patológica desde la cual el cadáver forma parte del campo médico.

El cuerpo se ve entonces desde la lectura de los tejidos, de los órganos, de sus funciones y desde esta lectura la relación que se establece con la enfermedad es la de observar el grado de afectación que esta causa en los órganos con el fin de buscar peculiaridades semejantes entre unas y otras enfermedades con el fin de vincularlas por grupos de familias, esta es la medicina patológica que tal como la define Foucault (2004): "ha sido ordinal antes de ser localizadora" (p.186).

Sin embargo al hacer las autopsias en los cadáveres se encuentra el cuerpo médico con otra dificultad: distinguir los signos propios de la muerte de los signos que han dejado los síntomas y el desgaste de los órganos producidos por la enfermedad, de tal manera que plantea Foucault (2004) la necesidad de: "ejercer la disección en cuerpos sanos" (p.152), con el fin de distinguir entonces los cambios que van apareciendo con cada enfermedad y como en el momento de la muerte el cuerpo ha cambiado

De esta manera la relación que la relación entre médico y enfermo en la medicina patológica se establece desde la mirada del médico como conocedor de los síntomas, lo que determina Foucault (2004) como: “el médico y lo patológico se pertenecen”(p.195), pues es el 
médico el único sujeto capaz de hacer un inventario de la patología que deja la enfermedad en el cuerpo del individuo, de manera que el cadáver ahora totalmente exteriorizado y expuesto se vuelve revelador de la realidad de la enfermedad, lo cual se muestra a la mirada y examen del médico.

Es así que la muerte se ve como el fenómeno por excelencia de la enfermedad, pues es lo último que puede hacer ella en el cuerpo a la vez que se puede ver como el límite alcanzado y cumplido de la vida, también la muerte es un hecho que puede cambiar el cuerpo del individuo dadas sus alteraciones propias, de manera que se entrecruzan los cambios producidos por la enfermedad con los cambios producidos por la muerte. Así entonces se impone a la medicina el nuevo reto de hacer la disección del cadáver lo más rápido posible antes que la muerte evidencie sus propios cambios en el cadáver. Sin embargo es desde la misma muerte que se pueden ver con toda seguridad las secuelas de esta, como desde la altura ver el paisaje, así entonces se puede establecer una relación inseparable entre vida, enfermedad y muerte, pues la vida se ve amenazada por la enfermedad que a su vez culminará en la muerte y esta a su vez sucederá la vida.

La muerte vista de esta manera pasa a ser el lugar privilegiado de iluminación por el cual la enfermedad y todas las señales del cuerpo se pueden evidenciar ahora desde la mirada que se hace en el cuerpo vivo y las pequeñas muertes que se dan en los órganos cuando sobreviene la muerte. Por tanto el cuerpo observado como una identidad propia del individuo con unas funciones propias, ahora con la muerte se ve como tal, por encima de como se había visto en vida: el espacio donde se desarrolla la enfermedad. Mientras que en la vida la interpretación del cuerpo se da desde lo que hace visible la enfermedad, es decir los síntomas, lo que determina Foucault (2004): "la enfermedad no será sino la forma patológica de la vida" (p.217).

La medicina patológica también centra su atención al observar la muerte, pues si la enfermedad es una amenaza constante a la vida, no necesariamente esta es causa de muerte, ya que la muerte es inherente al ser humano esté enfermo o no. Desde aquí se ha abierto una nueva visión del cuerpo: ver al individuo, ya que se da la posibilidad que en unos individuos se dé la enfermedad, en otros no y los síntomas de la enfermedad se dan en distintas formas o con 
diferentes peculiaridades en cada individuo, así entonces es cuando se valoran los comportamientos del individuo, sus actividades, su historia a la vez que se toman en cuenta aspectos como: edad, sexo, contextura física, etc., con lo cual se fijan las bases de la individualidad, que en el siglo XIX es cada vez más utilizada en el momento de definir como la enfermedad se desarrolla en el ser humano. Sin embargo para que el individualismo se pudiera tener en cuenta en la medicina fue necesario, según Foucault (2004) que: "la muerte se ha convertido en el a priori concreto de la experiencia médica, es cuando la enfermedad ha podido desprenderse de la contranatura y tomar cuerpo en el cuerpo vivo de los individuos" (p.276).

\subsection{Represión moral}

Haciendo una revisión de la historia occidental se puede decir que la sexualidad humana ha sido reprimida desde las creencias religiosas cristianas que han permeado las normas culturales con el fin de mantener también un orden social y político.

En este orden social es evidente la visión que la religión tiene de la mujer de manera que se ha justificado la represión al cuerpo y la sexualidad femenina desde la visión del hombre como superior a la mujer y que naturalmente debe dominarla, pues ella no es capaz de responder por sus actos.

En el siglo XII la Iglesia católica centra su atención en las mujeres como respuesta a sus continuas quejas al sentirse abandonadas y poco guiadas en el camino de la salvación, entonces en este momento los sacerdotes cristianos vuelven su atención sobre las mujeres, sin embargo parten del principio de pensar que la mujer es portadora del mal, lo cual lo justifican con el relato del génesis: "la mujer que me diste por compañera me dio del árbol y comî" Gn 3,12.

George Duby (1998) en su investigación sobre las mujeres del siglo XII, cita los sermones de fin de siglo en los que identifica tres vicios principalmente que se les atribuyen a las mujeres:

1. Desviar el curso de las cosas, oponiéndose así a los designios divinos, utilizando en muchas ocasiones la culinaria para alcanzar sus objetivos, pero no solamente se utiliza este arte, a la mujer se le acusa de preparar ungüentos y esencias para cambiar su apariencia, lo cual no es aceptado por los clérigos del tiempo pues para ellos es una ofensa contra Dios el no aceptar el cuerpo como imagen de lo que él ha creado, en palabras de Duby (1998): "cuál más, cual menos, todas brujas, las damas elaboran minuciosamente entre ellas sospechosas mixturas, comenzando 
por los afeites, los ungüentos, las ceras depilatorias que utilizan, trasvistiendo su apariencia corporal para presentarse, engañosas, a los hombres"(p.16), con lo cual se hace una acusación a la mujer quien prepara y utiliza cualquier elemento para cambiar su apariencia, se le identifica con la bruja.

2. No aceptar la dominación de un varón, por lo tanto se les acusa de querer dominarlos por medio de sustancias y embrujos con el fin de debilitarlos, porque por naturaleza la mujer es hostil al dominio de su marido y entonces lo primero que hace es engañarlo con un amante.

3. La lujuria, lo cual constituye toda la fuente de la maldad de la mujer, pues según los clérigos de la época es lo que hace que la mujer siendo incapaz de controlar su sensualidad natural comience a buscar amantes, pues no quiere dejarse dominar por el marido y este no le es suficiente. Así entonces la mujer que no está en capacidad de contener sus deseos (por eso es necesario el control masculino), comete pecados como el adulterio y el "pecado contra natura".

Es por estos vicios entonces que a la mujer se le considera enemiga natural del hombre, ya que gracias a sus seducciones y su poder para cambiar las cosas se suscitan riñas, malentendidos y demás conflictos que afectan la capacidad del hombre para mantener el orden por medio de la razón.

Es entonces cuando al interior de la Iglesia comienzan a darse los cánones o manuales entre los que sobresale el "Correcto o Medicus", citado por Duby (1998), que enseña a los confesores sobre las faltas que cometen los creyentes, las penitencias que se les debían imponer y sobre todo las preguntas que se deben hacer para que el penitente no olvide ninguno de los pecados. De esta manera la Iglesia católica cumple una función de vigilancia y castigo pues el confesor tiene la potestad de interrogar todos los detalles de la vida privada del creyente e imponerle los castigos que la misma norma determine. En esta misma confesión y la penitencia impuesta se evidencia que el castigo es más duro y visible para la mujer que para el hombre, ya que para él las penas son más laxas y privadas.

Estos manuales de confesión cuentan con preguntas para hombres y varias preguntas reservadas a las mujeres con el fin de buscar en ellas signos de lujuria, considerado como el pecado por excelencia de la mujer. El cuestionario se fija en acciones como utilizar instrumentos para el acto sexual, buscar el placer teniendo contacto sexual con otras mujeres o con animales, 
así como preguntas sobre el acto sexual con el propio marido o la utilización de afrodisiacos o sustancias que prolonguen el acto sexual. La finalidad de todas las preguntas es indagar sobre la búsqueda de placer en la mujer (Duby, 1998).

Las preguntas hechas a la mujer no son solamente sobre los temas antes descritos, pues también se la acusa de tener control sobre la muerte, sobre todo la muerte de los hijos no nacidos, fruto de la búsqueda de placer o su responsabilidad en la vida de los hijos pequeños, además de la pregunta sobre el hacer venenos o pócimas para asesinar a su marido, con el afán de quitarse su yugo de encima o se le acusa de propiciar debilitamiento de la virilidad masculina.

De aquí se deriva que a la mujer se le asocie con manipular sustancias o hierbas con el fin de transformar la voluntad de los individuos o causar daños, lo que en consecuencia se asocia con la brujería.

En el texto de Julio Caro Baroja: Las brujas y su mundo (1997), se profundiza sobre este aspecto, primero desde una perspectiva histórica: identificando que en algunos grupos primitivos del Neolítico europeo lo masculino se asocia con el sol, el día y la vida y lo femenino se asocia con lo lunar, la noche y la muerte, al mismo tiempo que se puede asociar con lo que identifica Caro (1997): "ciclo matriarcal agrícola" (p.40). En estos grupos la mujer tenía un papel importante no solo como cultivadora, sino como sacerdotisa o enlace con los ciclos lunares y su influencia en la agricultura. Este papel implica también lo que denomina Caro (1997): “actuaciones mágicas maléficas” (p.50), reservadas para determinado tipo de mujeres.

La otra perspectiva que toma Caro Baroja, es la perspectiva mitológica: Es evidente que se utiliza la magia para obtener algunos fenómenos naturales y también para hacer mal a las personas o a sus bienes o en caso extremo de causar la muerte. Sin embargo se encuentra en todos los casos lo que llama el autor "magia erótica" porque está ligada a la relación de los sexos y al deseo. (Caro Baroja, 1997).

Es importante mencionar las tres divinidades protectoras de la magia maléfica, mencionadas por Caro Baroja (1997): Diana, Selene y Hécate que se consideran divinidades “ctónico-lunares" (p.67) y además comparten unas características peculiares en cuanto a la 
sexualidad: son vírgenes, renuncian a la compañía masculina y a la fecundidad como expresión del amor. A estas divinidades protectoras el autor añade a Circe como la representación de la seducción, el arte del encanto femenino, la sensualidad femenina, teniendo en cuenta este último como instrumento para dominar a los hombres; y finalmente menciona a Medea quien se presenta como la tragedia y la venganza contra el marido desleal, lo cual implica el utilizar el mal manifestado en la hechicería.

Estas características otorgadas a tales divinidades serán las mismas que se les atribuyan a las mujeres a quienes se les relacione con la brujería, que en su mayoría poseerán una personalidad fuerte, adversa al dominio masculino y chocante con este.

Sin embargo es con el triunfo del cristianismo que se inicia una situación de persecución contra cierto tipo de mujeres, aunque en un principio la persecución del cristianismo se da hacia todo tipo de creencia pagana, equiparando sus dioses a demonios y todos sus cultos asociándolos con prácticas de hechicería. De manera que la legislación cristiana en el Imperio romano se encargó de condenar de manera estricta tanto la idolatría como la práctica de la magia, lo que se puede ver según el Caro Baroja (1997) al citar el Código Teodosiano en su libro IX, título 18 en el que se condena con pena capital a quienes celebren "sacrificios nocturnos en honor de los demonios o invocaran a éstos" (p.94).

Sirve también esta persecución para acusar a pueblos rivales o enemigos de practicar la hechicería o descender de hechiceras, así como acusar a hombres dedicados a la ciencia o algún tipo de investigación curativa de ejercer la hechicería y con ella conseguir resultados distintos a los convencionales. De manera que la hechicería será la excusa para invalidar los argumentos de la ciencia y las victorias de los pueblos rivales.

Esta persecución que inicialmente se hace desde la legislación cristiana se extiende y pasa a la legislación civil con el fin de condenar no solamente la magia, sino las prácticas y creencias paganas, lo cual Caro Baroja (1997) identifica como el pretexto para acercar al cristianismo a sectores de la población que aún no estuvieran en él y que por simple miedo a ser juzgados se convirtieran a la nueva y predominante religión (Caro Baroja, 1997). Es entonces en este 
contexto de la legislación civil que se comienza a juzgar a poblaciones enteras acusándolas por sus prácticas religiosas y modo de vida, sometiéndolas a extensos interrogatorios y formas de suplicio cuyo fin es hacer hablar, hasta el punto que los inocentes dicen lo que quieren escuchar los jueces y se hacen juzgar por delitos no cometidos.

Es de resaltar que la mayoría de las personas juzgadas por delitos de paganismo y hechicería son mujeres puesto que siguiendo los textos bíblicos, pues para algunos autores paganos y Padres de la Iglesia, citados por Caro Baroja (1997): la mujer es mucho más propensa a caer en el mal que el hombre, y más débil para dejarse seducir por el diablo, afirmaciones como: "mujeres son dadas a la Hechicería", "cuantas más mujeres, más Hechicería", "la mayoría de las mujeres son hechiceras"(p.147), salidas de comentaristas talmúdicos del capítulo XXII del Éxodo: "a la hechicera no dejarás que viva" de donde se desprende la pena a la cual están abocadas las mujeres que se encuentren culpables de este delito, siendo así las mujeres las principales víctimas de la acusación y consiguiente juicio por hechicería, convirtiéndose la hoguera en la máxima pena para las hechiceras de la Edad Media.

Entonces la hechicera se puede entender desde el pensamiento de Giorgio Agamben (2006) como el "homo sacer" (p.20), cuya vida es insacrificable, pero por otro lado cualquiera puede sacrificar siempre y cuando se compruebe la culpabilidad de los delitos que se le imputan y las faltas cometidas por estas mujeres hacia lo sagrado.

Siguiendo con la tesis de Agamben se puede interpretar la muerte en la hoguera como un sacrificio más no como un asesinato, pues quien muere allí ha de ser purificado de todas sus faltas contra la religión y de las ofensas hechas a Dios y los males hechos a los demás por medio de la utilización de la hechicería. Por otra parte el poder de quitar la vida o castigar por una culpa según Agamben viene dado al pater como la cabeza, e inicialmente se da en la relación de padrehijo, como expresión del poder político que se le da a todo ciudadano libre, poder que se transfiere a las leyes, quienes son finalmente quienes juzgan y determinan la condena del ajusticiado (Agamben, 2006).

Es evidente que la persecución a la hechicería, la magia y el paganismo es en realidad la expresión de intereses políticos de parte de la Iglesia católica y los gobernantes, ya que la primera 
buscaba atemorizar a la población y llevarlos a la conversión para tenerlos entre sus fieles y de parte de los gobernantes, tener una legislación estricta que mantuviera a la población dentro de costumbres aceptadas por el cristianismo, sin que se distrajeran en otras creencias y costumbres.

Se puede entender esta forma de persecución desde la biopolítica de Foucault (2002) como la visión de un cuerpo viviente convertido en una estrategia política y teniendo en cuenta el contexto también religioso, al buscar a través de "cuerpos dóciles" (p.180), torturados a través del interrogatorio y la tortura para mantener una disciplina y un orden muy convenientes tanto para el poder civil como para el poder eclesiástico.

\subsection{La segregación de la norma}

En cuanto a la norma uno de los aportes que hace Michel Foucault, se puede encontrar en el curso titulado Los Anormales (2007), de los años 1974-1975, en el cual plantea la discusión de lo normal y lo anormal desde el análisis del "cruce de tres elementos: el monstruo humano, el individuo a corregir y el onanista” (p.299), casos que plantean problemáticas para el poder en el siglo XIX, que lo llevarán a elaborar discursos y prácticas de control que buscan darles legitimidad. Desde aquí se tomarán entonces dos aspectos en consideración: el orden discursivo y el orden de las prácticas que surgen de este discurso. Estos dos aspectos sin embargo en un primer momento se analizan desde el texto de la Historia de la locura en la época clásica, para luego profundizarlos desde el curso: Los Anormales.

En este texto, Foucault devela el carácter histórico de la locura como una forma "desviada" de lo aceptado como saludable, en el volumen III (1998) del texto mencionado, Foucault muestra las variadas explicaciones que se le buscan dar a la locura, como por ejemplo: "que es causada por los cambios de clima o por las fases de la luna"(p.19), explicación que demuestra una forma diferente de explicar la locura a la que da el pensamiento griego desde el paso de lo mítico a lo lógico, explicando Foucault (1998) la locura como: "la irrupción de la animalidad, en el ámbito de la cultura y del hombre"(p.26), es decir la locura aparece como lo contrario a la razón del hombre.

Poco a poco Foucault va ahondando en la forma como se va interpretando el origen de la locura, hasta llegar al campo psiquiátrico de manera que se pasa de buscar una explicación 
exterior al sujeto a una explicación dentro de este mismo, de manera que esta búsqueda se vuelve más valorativa de las conductas del sujeto y menos investigativa desde lo cotidiano, lo aparente y lo moral. Sobre esta valoración psiquiátrica que considera lo normal-anormal desde la salud, ámbito en el cual también se pueden traslucir otras formas como lo feo-bello, bueno-malo, relacionando por consiguiente lo anormal con lo no virtuoso o lo no agradable estéticamente. De manera que lo considerado normal puede estar definido por la valoración médica que le da carácter de verdad y validez a estas formas sociales.

Esta legitimidad que se ha ganado la medicina dentro de la sociedad se la adjudica Foucault a lo que denomina "medicalización", que finalmente va a ser la forma como la medicina entra en el funcionamiento general del discurso y el saber científico a través de una medicina colectiva, social y urbana. Es a través de este concepto que se muestra como la práctica médica entra en todo orden social desde los asuntos más privados del cuerpo, el análisis del medio sobre el organismo y finalmente todo lo relacionado con este.

Así la medicina entra a analizar la enfermedad como lo considerado fuera de lo normal, desviado, o irregular que finalmente será el centro de atención de la ciencia que a su vez parte de lo regular es decir lo que se considera parte de la norma. Lo normal se puede entender desde la lógica como la regla que está confirmada por la excepción, de manera que la dupla normalanormal se sostiene en oposición siendo un complemento y necesidad de la otra.

Entonces la enfermedad que se desplaza de lo particular de quien la sufre a un problema poblacional, requirió no solamente discursos sino instituciones que les legitimaran, a partir de un interés político y económico, como lo enuncia Foucault en la Historia de la locura (1998): considerando que la locura deja de ser extraña para pasar a verse desde significaciones psicológicas que son la causa para que la sociedad burguesa considere encerrar a quien padece la locura para tratarlo y para alejarlo del resto de la sociedad, como en otro tiempo se había hecho con los leprosos (Foucault, 1998), de esta manera al unir la locura desde un discurso psicológico, con el discurso jurídico se genera una lógica en la que se decide quien tiene derecho a circular por el mundo de forma libre y quien debe ser recluido. 
Al ver la locura como algo que se sale de lo racional, se puede entender esta como algo desconocido que necesita ser clasificado, jerarquizado o en últimas estigmatizado provocando descredito en el individuo que la sufre, de manera que tal estigma demuestre la anormalidad de quien la sufre, por tanto desde este solo hecho ya se dan separaciones en el modo de relación social origen de la segregación, de manera que el señalar a otro como anormal no solamente ocasiona un distanciamiento de este del resto de grupo, sino que reafirma a quien estigmatiza como individuo normal.

De manera entonces que quien es etiquetado con respecto a las reglas de grupo es llamado anormal, de manera que esta condición es creada por el mismo grupo y no hay unas reglas universalmente acordadas que determinen la "anormalidad", pues lo que es anormal para un grupo, para otros no lo es.

Entonces en el ámbito social, el uso del poder que determina lo natural y normal debe estar muy bien elaborado de manera que sea poco perceptible y casi que impensable en la sociedad, con el fin que la estigmatización de un grupo considerado enemigo por no compartir los elementos comunes con este, justifique su encierro y exclusión de lo determinado por la mayoría, sin embargo para ello es necesario sustentar los discursos en instituciones que los hagan realidad, ya que los discursos si no están sustentados en instituciones que los oficialicen son solo sentido común. Por lo tanto se genera un nuevo análisis entre las dicotomías: normal-anormal y centroperiferia para entender que los saberes están ubicados de forma estratégica en el mapa social, de manera que se excluya todo saber y discurso que intente poner en cuestión un oficialismo que pretende ejercer un control desde el poder al interior de la sociedad.

De esta manera el señalamiento es la expresión de una forma de poder con el fin de estigmatizar a los individuos, para que una vez hecho esto se pueda justificar el dar un tratamiento determinado como son lugares y zonas para cierto tipo de población como expresión del control ejercido por el poder al interior de la sociedad, de esta manera el cuerpo del individuo se convierte en un elemento de control apropiado por una lógica de poder que determina lo apropiado y lo que se determina como no apropiado. 
Derivándose de esta práctica de estigmatización y vigilancia continua deviene entonces la corrección, término que podemos desarrollar en los tres elementos señalados en el principio de este apartado: el monstruo humano, cuyo marco de referencia plantea Foucault es la ley, pues la monstruosidad viene dada por la violación a la ley jurídica y también a la ley natural, como lo identifica Foucault (2007): "el campo de aparición del monstruo por lo tanto, es un dominio al que puede calificarse de jurídico biológico"(p.61) y la forma como se corrige a este tipo de hombre es por medio del encierro y la vigilancia continua.

El segundo elemento es: el individuo a corregir, que ubica Foucault (2007) específicamente entre los siglos XVII y XVIII y le da como marco de referencia "la naturaleza y la sociedad"(p.63), encontrando este individuo con mucha más frecuencia que el anterior, pues el individuo a corregir se encuentra en las relaciones que establece la familia con la escuela, los sitios de trabajo, el barrio, la iglesia, etc, de manera que es lo que llama Foucault (2007) un "modelo en aumento" (p.62) y a la vez difícil de hallar pues no tiene nada de extraordinario en su cotidianidad, solamente que las distintas instituciones a su alrededor han intentado corregir y no lo han podido hacer por lo tanto exige un trato especial de ellas, lo que identifica Foucault (2007) como el "juego entre incorregibilidad y corregibilidad”(p.64), que será en el siglo XIX la condición determinante de la anormalidad.

El tercer elemento es: el masturbador, a quien ubica Foucault (2007) en el siglo XIX en la familia y su marco de referencia es el dormitorio como espacio personal y su cuerpo, es decir el “individuo y su cuerpo"(p.64), se ubica en el siglo XIX porque aunque obedece a un universal secreto que aunque todos lo practican es un secreto del que nadie habla, de manera que es hasta este momento cuando la medicina culpa a la masturbación de ser la responsable de enfermedades corporales, nerviosas y psíquicas de manera que en este siglo todas las enfermedades se fundarán en causas sexuales de manera que este universal utilizado y callado por la mayoría será la principal causa de enfermedad y de las anomalías sexuales. La forma de corrección para este tercer elemento es la continua vigilancia y la estigmatización de la enfermedad causada por el onanismo.

Sin embargo estos tipos de corrección no han sido, ni son los únicos que se dan para el individuo estigmatizado de anormal, pues en la actual sociedad consumista cada vez son más 
populares prácticas como las dietas, las cirugías, la psicoterapia, los medicamentos de todo tipo para corregir lo que aparece a los ojos de quien señala como algo anormal. Por tanto se pude plantear que este señalamiento de anormalidad puede provenir de intereses particulares que buscan beneficio personal.

En cuanto a la estigmatización y el señalamiento de anormalidad se puede evidenciar que va dando sus frutos y cada vez son más numerosos los señalamientos de anormalidad de todo tipo en la sociedad de manera que se van constituyendo a forma de visibilidad cada vez más grupos de personas que se identifican entre ellas señaladas de cierta "anormalidad" y a partir de sus desgracias originan terapias para afrontar mejor lo que se les ha mostrado como su adversidad.

\subsection{Las reivindicaciones legales de los segregados}

En este último apartado encuentro que se da la cuestión de la legislación en cuanto a la legislación general para todos los ciudadanos por igual o la legislación que busca dar leyes que cobijen a un determinado grupo social o considerado diferente por un tipo de condición, lo cual estaría promoviendo hacer grupos aislados para buscar el reconocimiento legal de sus intereses particulares. Así entonces es necesario entrar en el campo del multiculturalismo para comprender desde el mismo término las diferencias de la realidad cultural presentes en los grupos excluidos por sus preferencias sexuales. Este término inicialmente utilizado por Will Kymlicka para integrar los grupos de varias procedencias étnicas presentes en una región, sin embargo hace ver el mismo autor que el término se ha utilizado para incluir de manera más amplia a grupos sociales que han sido excluidos de la mayoría de la sociedad, lo cual demuestra que el término cultura debe ser entendido más allá de lo étnico. Así entiende Kymlicka (1996) que: "Si cultura alude a las "costumbres" de un grupo, resulta obvio que los diversos grupos con estilo de vida propios, los movimientos sociales y las asociaciones voluntarias que podemos encontrar en cualquier sociedad moderna poseen sus propias "culturas"”'(p.35), dando como resultado naciones multiculturales.

En estas naciones multiculturales se dan también situaciones de marginación de determinados grupos denominados minoritarios como son las mujeres, las comunidades LGBTI, los discapacitados, solo por nombrar algunos de estos grupos. Para Kymkicka las exigencias de justicia de estos grupos y de los grupos de personas provenientes de diversidad étnica, guardan 
profundas similitudes por su condición de diferencia y ser excluidos de una sociedad considerada mayoritaria. Sin embargo para Kymlicka no se pueden poner en el mismo plano, pues los grupos sociales marginados, lo han sido en su mismo grupo cultural o étnico (Kymlicka, Will, 1996).

Otro aspecto que se debe tener en cuenta con respecto a las minorías es su falta de representación en las instituciones del gobierno ya que la mayoría de representantes son hombres blancos, heterosexuales, de clase alta o media y que no padecen ninguna discapacidad, de tal forma que estos grupos no son visibles, pues no están representados en los estamentos de gobierno, por lo tanto considera Kymlicka (1996) que es necesario: "hacer que los partidos políticos sean más inclusivos, socavando las barreras que inhiben a las mujeres, a las minorías étnicas, o a los pobres, a convertirse en candidatos o dirigentes del partido"(p.54), con el fin que estos grupos excluidos y minoritarios tengan visibilidad en los estamentos de gobierno y se reconozcan sus derechos de forma efectiva.

Sin embargo para Kymlicka es mucho más importante que los gobiernos trabajen por promover y garantizar los derechos de toda la población y no tener que elaborar leyes propias para cada grupo, pues estas no son más que el resultado o la respuesta a procesos de opresión y desventajas para los miembros de estos grupos en la sociedad. Por lo tanto sería más meritorio que las sociedades no necesitaran de medidas y legislaciones especiales para hacer cumplir desde la igualdad los derechos de cada uno de los sujetos que la conforman, y por el contrario valorar la singularidad de cada uno y la riqueza de la diversidad de formas de pensar y vivir.

Este tema da como resultado el debate entre los derechos individuales y los derechos colectivos, considerando los primeros como los provenientes de una sociedad democrática liberal que tiene como compromiso básico, como lo expresa Kymlicka (1996): "la libertad y la igualdad de sus ciudadanos individuales"(p.57), mientras que al considerar los derechos colectivos: los individuos pasan a ser solamente miembros de un grupo determinado y sujetos de un objetivo grupal, en palabras de Kymlicka (1996): "los derechos diferenciados en función del grupo parecen reflejar una perspectiva colectivista o comunitarista más que la creencia liberal en la libertad y la igualdad de los individuos"(p.57). 
Siguiendo la perspectiva del respeto a los derechos individuales se propone la pregunta: ¿En Colombia se promueven y se respetan los derechos fundamentales de todos los individuos? A primera vista y teniendo en cuenta la Constitución Política Nacional se puede decir que si, de acuerdo a los siguientes artículos:

Artículo 5: El Estado reconoce, sin discriminación alguna, la primacía de los derechos inalienables de la persona y ampara a la familia como institución básica de la sociedad. Y en el Artículo 13: Todas las personas nacen libre e iguales ante la ley, recibirán la misma protección y trato de las autoridades y gozarán de los mismos derechos, libertades y oportunidades sin ninguna discriminación por razones de sexo, raza, origen nacional o familiar, lengua, religión, opinión política o filosófica. El estado promoverá las condiciones para que la igualdad sea real y efectiva y adoptará medidas a favor de grupos discriminados o marginados.

Se puede ver en el artículo 13 que se hace la observación con respecto a los grupos discriminados o marginados, por lo tanto se está haciendo referencia a un trato especial para ciertos grupos que se pueden considerar oprimidos o en desigualdad de condiciones con respecto a los demás grupos de la sociedad. Por lo tanto la Constitución Política Nacional estaría fijándose en los derechos colectivos, teniendo en cuenta la multiculturalidad presente en la sociedad, sobre el ciudadano individual. Según María Teresa Uribe de H.: se habría iniciado con la inclusión de los derechos civiles para seguir con los políticos y sociales culminando con los culturales para reencontrar así, en la Nueva Constitución y a las puertas del siglo XXI, las comunidades y las etnias perdidas (Uribe de H, María Teresa, 1996, p.143).

De manera que la Constitución de 1991 reconoce los derechos culturales de las comunidades que se habían mantenido a la sombra, de los derechos individuales, más sin embargo este reconocimiento también supone la vivencia de estos en la acción social, las prácticas culturales y las vivencias del día a día de estos grupos sociales y étnicos, lo que expresa María Teresa Uribe (1999):

Ese contrapunto entre comunidades y ciudadanos tiene su expresión en los corpus constitucionales y en la manera como se articulan en ellas los derechos individuales y colectivos pero también en la acción social, en las prácticas culturales, en los usos, costumbres y modos de resolver - en la práctica- los problemas de la autoridad, el poder, la obediencia, la jerarquía, la justicia y la convivencia social. (Uribe de H., María Teresa, 1999, p.144). 
Es en este sentido; en la vivencia diaria de los derechos promulgados por la Constitución donde se encuentra la gran dificultad para los grupos de personas LGBTI, ya que es en la realidad y vida diaria de estas personas donde estos derechos no encuentran consistencia, como se presenta a continuación:

Según Colombia Diversa (2011) los temas que se consideran más críticos y urgentes en relación con las personas LGBTI tienen que ver con: "violencia por prejuicio, abuso policial, derechos de las parejas del mismo sexo, situación carcelaria y desplazamiento forzado" (p.7). Si bien es cierto que en los años 2008 y 2009 se dan cambios definitivos en los derechos fundamentales para las parejas del mismo sexo como son reconocimiento de los derechos de las parejas del mismo sexo en unión marital de hecho, afiliación de compañero (a) permanente a servicio de salud, recibir pensión de sobrevivencia al enviudar, demandar penalmente por alimentos, así como otros derechos civiles, políticos, económicos y sociales que se consideraban exclusivos para parejas heterosexuales. En estos años también los medios de comunicación hablaron e hicieron visible temas sobre la situación de las parejas del mismo sexo, que antes no se habían tocado públicamente. Con estos reconocimientos jurídicos se inicia un camino hacia el reconocimiento de estas personas, como lo expresa Marcela Sánchez (2011): “sujetos sociales y políticos" (p.9).

Sin embargo el hacer visible estas situaciones generó en la sociedad una fuerte resistencia, pues tradicional y religiosamente la sociedad se ha entendido para personas heterosexuales y desde esta visión se comprende el individuo, la pareja y la familia.

El primer paso para gozar plenamente de los recién reconocidos derechos, es que las parejas debían acercarse a instituciones como comisarías de familia o juzgados de familia para declarar la relación de hecho. En este proceso denuncia Colombia Diversa que se encontraron muchos obstáculos de funcionarios, instituciones y resistencias en el proceso. Al tiempo que en el Congreso de la República en dos oportunidades se debatió un proyecto de ley a favor de las parejas del mismo sexo y en las dos oportunidades el proyecto se hundió. Adicional a esta situación se encuentran las solicitudes de adopción de parejas del mismo sexo y la constante negación de estas por parte del ICBF por considerar, según Marcela Sánchez (2011) que: "según 
la Constitución Política de Colombia, una familia sólo puede ser considerada como tal si está conformada por un hombre y una mujer" (p.9).

Sumado a estas situaciones se encuentra la posición de instancias de poder como la Procuraduría General de la Nación en cabeza de Alejandro Ordoñez de posición abiertamente adversa a los derechos sexuales y reproductivos de las mujeres, la población LGBTI y de los jóvenes.

En cuanto a la situación del día a día que viven las personas con opciones sexuales distintas a la heterosexual, se encuentran los asesinatos, que según investigación de Colombia Diversa (2011) en el momento de la investigación las autoridades califican como "crímenes pasionales" (p.15), desvirtuando inmediatamente la naturaleza del delito y quitando responsabilidad al victimario; se encuentran también en este campo los homicidios por prejuicio por orientación sexual o identidad de género y en los cuales las autoridades encuentran más difícil establecer los culpables pues alrededor de la víctima se encuentra todo un grupo de personas que no estaban de acuerdo con la identidad sexual del agredido y todos se convierten en sospechosos.

En cuanto a la investigación de los homicidios de personas LGBTI se encuentra también que los encargados de hacer las investigaciones caen en formular prejuicios como "sólo se sabe que lo visitaban muchos hombres"24(p.19), lo cual inmediatamente constituye una revictimización de la persona asesinada pues le da culpabilidad y responsabilidad en su propio asesinato e inmediatamente quita responsabilidad del victimario.

En cuanto a la identidad de la persona asesinada si se trata de mujeres transgeneristas en el expediente solamente se le da la categoría de "homosexual", con lo que se está invisibilizando su identidad de género.

Otra situación enunciada por Marcela Sánchez (2011), que demuestra la falta de garantía en cuanto a los derechos de personas LGBTI es el abuso de autoridad policial basados en prejuicios sociales e incluso protegidos en "instrumentos legales que regulan la actividad policial -específicamente los códigos de Policía”(p.41) y de alguna manera dan las bases para que se

\footnotetext{
${ }^{24}$ citando la respuesta de la Fiscalía 27 de Unidad de Vida de Cali a Colombia diversa. 31 de agosto de 2009
} 
vulneren los derechos de las personas LGBTI, ejemplo de esto son las disposiciones legales presentes en el código de policía que dictan normas específicas para las personas de la comunidad LGBTI, expuestas por Colombia Diversa (2011):

Para mantener una sana convivencia, la comunidad gay deberá atender, entre otros, los siguientes comportamientos: 1.Abstenerse de adoptar actitudes provocadoras e incitantes con otras personas, que puedan colocar en riesgo su seguridad y la de su comunidad...4.Abstenerse de sacar provecho ilícito de su condición de población en situación de vulnerabilidad y evitar el exhibicionismo $^{25}$ (Sánchez, Marcela, 2011, p.42)

Lo que claramente constituye una ley discriminatoria pues promulga normas específicas para personas LGBTI, así como dar un amplio margen para que los miembros de la policía determinen los comportamientos que consideren "provocadores e incitantes". Estas situaciones dan pie a que se presenten casos de abuso policial.

Una tercera situación que atenta contra los derechos de personas LGBTI, es la situación carcelaria que viven quienes están recluidos en penitenciarias y que según denuncia Colombia Diversa (2011) son víctimas de violencia verbal, violencia física y violencia sexual y además en el momento de hacer las investigaciones los funcionarios encargados no toman en serio las denuncias e incluso llegan a cuestionar las violaciones por considerar que a estas personas "les gusta eso"(p.74) y que por su condición sexual este tipo de conductas se convierten en algo “connatural al proceso de adaptación a la cárcel”(p.74).

Aquí nuevamente se hace presente la invisibilización de la víctima y se le da responsabilidad y culpa solamente por su orientación sexual.

Una cuarta situación de atentado contra los derechos humanos se desprende desde la misma Constitución Política Nacional en el reconocimiento de familia como la "unión de un hombre y una mujer" (Artículo 42), de manera que las demás uniones se consideran entonces como otro tipo de familia y por lo tanto ya, solo con este hecho se les está discriminando y sus derechos no son los mismos que los de las familias conformadas por uniones de hombre y mujer.

\footnotetext{
${ }^{25}$ citando la Ordenanza 000018 de 2004 que expide el Manual de convivencia y seguridad ciudadana del departamento del Atlántico.
} 
En la misma cotidianidad se dan situaciones para personas LGBTI que aunque no se nombran y no se encuentran en las situaciones descritas anteriormente si constituyen una clara discriminación, algunas de estas son: las personas con identidad transgenero tienen claras dificultades para estudiar por las continuas agresiones y burlas de las que son objeto de parte de sus compañeros, maestros y directivos de las instituciones, por lo tanto presentan bajos niveles educativos y tienen grandes dificultades para conseguir empleo, las personas con una abierta opción homosexual son discriminadas, despedidas de sus empleos o son hostigados por sus compañeros y/o sus superiores. En los medios de comunicación se hace presente una continua burla a las personas homosexuales en algunos programas de entretenimiento mostrando al homosexual como el personaje divertido, gracioso, chismoso, hablador e indiscreto pero quedándose solamente en esto y como un personaje que no se toma en serio. Continuamente la sociedad está quejándose de la impertinencia de las personas LGBTI y son percibidas como un riesgo para la comunidad y prefieren en algunos casos no convivir cerca de ellos, ni que se acerquen a menores de edad.

Según investigación realizada por la Secretaria Distrital de Planeación de Bogotá en el año $2010^{26}$, citada por Marcela Sánchez se encuentra que: un $45 \%$ de la ciudadanía percibe a las personas LGBTI como un riesgo por considerar que van contra las normas establecidas como son la moral, las costumbres y la idea de familia; aunque el $46 \%$ de la población nunca ha hablado, conocido ni compartido con estas personas, lo cual demuestra el prejuicio que existe en la sociedad hacía ellos (Sánchez, 2011).

Es en este contexto que la mayoría de personas LGBTI prefieren mantener su opción sexual en secreto y aunque vivan en pareja, esconden la relación por el temor a ser discriminados en primera medida por la familia, en su trabajo o estudio y en su ámbito social.

En todas estas situaciones se evidencia una clara intención de invisibilizar al otro por su opción sexual, sin tenerlo en cuenta como persona y como sujeto social y político.

\footnotetext{
${ }^{26}$ Investigación de base de la Política Pública para la Garantía plena de Derechos de las personas de los sectores LGBTI.
} 
Analizando las situaciones antes expuestas a la luz del pensamiento de Michel Foucault y la biopolítica es evidente que la sociedad moderna asemeja aún las prácticas sexuales diferentes a la cultural y religiosamente aceptada, con algún tipo de enfermedad mental y por lo tanto de anormalidad, pues la vivencia sexual no se encamina a su fin primario: la reproducción; lo que enunciaría Michel Foucault en la Voluntad del saber (2007): "Sin duda el "contra natura", estaba marcado por una abominación particular" (p.50), de esta forma es evidente que lo moralmente aceptado por la religión, es lo que la población encontrará como aceptable cultural y socialmente.

Por otra parte se evidencia un creciente nerviosismo de la población ante las sexualidades diversas, pues resulta que estas van saliendo a la luz y quienes optan por ellas reclaman por parte del Estado se les reconozca en igualdad de derechos sociales y políticos, de tal manera que al hacerse visibles estas vivencias diversas de la sexualidad la sociedad entra a preguntarse por el control y la disciplina, pues lo común y tradicionalmente aceptado deja de serlo para convertirse en una forma más de vivir de las personas dentro de una infinidad de posibilidades, de tal manera que el control sobre la voluntad de la población queda en entredicho, tal como manifestaría Foucault (2007): “Al parecer, la función del poder que aquí se ejerce no es la de prohibir” (p.54).

En el texto de Jürgen Habermas: La inclusión del otro (1999), el autor expone que para que se dé una política del reconocimiento desde: el pleno reconocimiento público como ciudadanos iguales puede requerir dos forma de respeto: 1) el respeto a la identidad intransferible de cada individuo, con independencia del sexo, raza o pertenencia étnica; y 2) el respeto a aquellas formas de acción, prácticas y concepciones del mundo que son objeto de un alto aprecio por los miembros de los grupos en desventaja o con los que están estrechamente vinculados. (Habermas Jürgen, 1999, p.191)

En estos grupos en desventaja se encuentran los grupos de personas LGBTI quienes además de pedir igualdad de derechos con los demás miembros de la sociedad, también se les debe garantizar protección en cuanto a sus formas de vida y tradiciones que finalmente es lo que dará el reconocimiento en cuanto grupo discriminado. Esto se logra mediante, lo que enuncia Habermas (1999): "una política que considere las diferencias culturales y, por otro lado, mediante una política de la universalización de los derechos subjetivos" (p.192), de esta forma 
garantizando los derechos y reconociendo las diferencias es como se afirma el total y pleno reconocimiento de las personas LGBTI como sujetos de derechos.

En cuanto a las políticas públicas para las personas LGBTI en Colombia no hay una política pública nacional, sin embargo existe una política pública en Bogotá (Decreto 062 de 2014) que da garantía plena de los derechos de las personas LGBTI en el cual se reconoce la necesidad de adoptar una política pública que garantice la protección de derechos de personas LGBTI, teniendo en cuenta las agresiones y abusos cometidos contra esta población. Este decreto tiene como objetivos:

“a. Consolidar desarrollos institucionales para el reconocimiento, garantía y restitución de los derechos de las personas de los sectores LGBTI.

b. Generar capacidades en las organizaciones y personas de los sectores LGBTI para una efectiva representación de sus intereses como colectivo en los espacios de decisión de la ciudad.

c. Promover una cultura ciudadana basada en el reconocimiento, garantía y restitución del derecho a una vida libre de violencias y de discriminación por identidad de género y orientación sexual.

d. Posicionar la perspectiva de géneros y diversidad sexual para la formulación, implementación, seguimiento y evaluación de las políticas públicas en el Distrito Capital." (Decreto 062/2014)

De manera que se busca dar participación a las personas e instituciones que propenden por garantizar el ejercicio pleno de derechos de personas LGBTI.

Entre otras cosas el decreto busca: eliminar la discriminación en el ámbito laboral mediante la creación de "Ambientes Laborales Inclusivos"(Artículo 7, parágrafo 1) inicialmente en las instituciones del distrito capital mediante la revisión y corrección de los manuales de funciones y procedimientos de estas instituciones; "Garantía del acceso, uso y disfrute de los sistemas institucionales de servicios públicos sociales"(Artículo 7, parágrafo 2b), con el cual se eliminan las barreras en servicios para las personas LGBTI, buscando el ejercicio efectivo de sus derechos o restitución de estos si han sido vulnerados; "corresponsabilidad en el ejercicio de derechos"(Artículo 8) mediante el cual se garantiza la participación individual y colectiva en la formulación de políticas públicas y de control ciudadano; "Visibilización y posicionamiento de la producción cultural de los sectores LGBTI como parte de la cultura ciudadana, la convivencia y la construcción de lo público"(Artículo 9b), con este se reconoce a las personas LGBTI como 
sujetos culturales y productores de cultura; "Escuela para la inclusión y la diversidad"(Artículo $9 b)$, con este componente se toca un tema vital para el desarrollo de una conciencia pública libre de prejuicios y discriminación. La escuela debe ser el espacio donde se formen ciudadanos que transformen la sociedad y la liberen de falsos imaginarios y prejuicios hacia las personas con una opción sexual distinta a la establecida desde la religión y la tradición.

Bajo este componente se puede enmarcar la política de la Secretaria de Educación Distrital: "Escuelas diversas y libres de discriminación" que en su eje 4:

Sexualidad y género busca: "que el abordaje de la sexualidad desde un enfoque diferencial y de género permite contribuir a la disminución de las desigualdades, inequidades o mitos que circulan, la ciudadanía como ejercicio de derecho de mujeres y hombres con cuerpos, corporeidades, identidades e historias particulares, adquiere gran relevancia al convertirse en un tema central en la construcción de la ciudadanía, en el ejercicio de derechos de las personas o poblaciones; así como en la transformación de imaginarios en las comunidades. ${ }^{27}$

De tal manera que la educación sea el medio y la escuela el espacio en el que hombres y mujeres se identifiquen desde la igualdad y desarrollen actitudes de una vivencia libre y autónoma de la sexualidad y el ejercicio de la ciudadanía.

En el eje 5:

Diversidad Sexual (LGBTI+H) busca: "transformar condiciones, actitudes, comportamientos y barreras que generan discriminación, exclusión, segregación, y marginación de la población LGBTI en las Instituciones Educativas Distritales. De esta manera se asegurar el reconocimiento, respeto, promoción y sostenibilidad de las acciones para la garantía plena de los derechos de personas Lesbianas, Gais, Bisexuales, Transgeneristas e Intersexuales (LGBTI)”,28,

De manera que la escuela sea un espacio de construcción, visibilización y reconocimiento de las orientaciones sexuales e identidades de género, así como el espacio de formación de personas que reconocen al otro desde su singularidad y desde el respeto. Sin embargo para nadie es secreto que aunque los manuales de convivencia busquen construir armonía al interior de las instituciones educativas los niños, niñas y jóvenes que se identifican diversos sexualmente, con frecuencia han sido objeto de burlas, violencia verbal y en algunos casos exclusión y violencia física.

\footnotetext{
${ }^{27}$ www.educacionbogota.edu.co/Educación incluyente

${ }^{28}$ Ibíd.
} 
Estas situaciones evidencian que la educación sexual en los colegios no está encaminada a valorar la diferencia del otro desde su opción de vivencia sexual, por lo tanto teniendo en cuenta este eje se hace necesario que desde la escuela se hagan propuestas pedagógicas que propendan por el respeto y la prevención de vulneración de derechos, hostigamiento y demás actitudes que vayan en contra de la vivencia de los derechos de personas LGBTI, así como propuestas de educación sexual desde un enfoque diferencial y de género que busquen la formación de personas que vivan su sexualidad autónoma y responsablemente al tiempo que conocen sus derechos sexuales y reproductivos y los ejercen como ciudadanos sujetos de derechos.

Una vez realizado este recorrido desde el tema de la sexualidad vista desde la cultura, la religión y la educación, teniendo en cuenta aspectos como el dominio del cuerpo desde la biopolítica y el dominio del alma ejercido desde la religión, es necesario situarla como una manifestación de la individualidad humana, guiada bajo la libertad de cada individuo, ante lo cual establezco una posición de pensamiento propia, además de encontrar la necesidad de construcción de una propuesta pedagógica que lleve a la formación de sujetos que valoren la diferencia.

Aunque en Colombia se hable cada vez más de diversidad sexual y la necesidad de garantizar la plenitud del goce de derechos para personas con vivencias sexuales no normativas, aun es evidente que la legislación colombiana está enmarcada dentro de una visión heterosexual, lo cual se evidencia en el lenguaje al excluir de leyes y códigos a población trans, así como enunciar un solo tipo de familia conformada por hombre y mujer y en cuyo interior solamente pueden crecer los hijos, negando de tajo la posibilidad de adopción a familias homoparentales, lo cual va en contraposición con el Artículo 13 de la Constitución Política Colombiana y de un reconocimiento a nivel mundial de la diferencia en la vivencia de la sexualidad.

Por último no se trata de pedir cada vez más políticas públicas que consideren de forma especial a las minorías sexualmente diversas, sino que las hagan iguales en derechos y deberes, se inserten en la dinámica social de forma igualitaria, posibilitando su participación de tal manera que todos ellos y ellas contribuyan con sus potencialidades, hábitos éticos y sus posibilidades a la construcción de una sociedad diversa, incluyente e igualitaria en beneficio de todos sus miembros. 


\section{CONCLUSIONES}

Después del análisis realizado a la sexualidad desde la biopolítica es importante destacar las siguientes conclusiones:

- Para los judíos la sexualidad es considerada un regalo del Altísimo y una experiencia vital, tan valorada que en ocasiones se utilizó para explicar el amor de Dios a su pueblo, como es el caso del Cantar de los Cantares que detalla el amor en pareja utilizándolo como paralelo al amor de Yahvé a su pueblo. Sin embargo la sexualidad es muy valorada en el matrimonio y prohibida fuera de él. Mientras que para los griegos hay un constante interrogante sobre el comportamiento sexual como postura moral y así definen formas de moderación, ya que surge la idea que la actividad sexual es bastante peligrosa y costosa, que debe haber abstinencia de todo placer "extraconyugal". Por tanto se desarrollaron tres grandes técnicas para la modulación de la conducta sexual: La Dietética, la Económica, la Erótica.

- Para el cristianismo es evidente la influencia de San Pablo y San Agustín en el tema de la sexualidad al interior del matrimonio y cuyo fin es la procreación, que para el obispo de Hipona, será la tarea de la mujer y su finalidad. Por otra parte el cuerpo que se considera determinante para la salvación, también lo puede ser para condenación; especialmente el cuerpo de la mujer que se considera motivo de escándalo y causa de pecado por lo tanto el cuerpo de la mujer debe evitar exhibirse, mejorarse y embellecerse. Así mismo el modelo de virtud virginal y de mujer perfecta es la figura de María, como mujer obediente y cumplidora de la voluntad de Dios.

- En el Nuevo Mundo es evidente la influencia de la tradición española y así mismo la influencia del cristianismo, instituyendo el matrimonio como el mecanismo que garantiza social y económicamente la unión de intereses familiares y sociales.

- En cuanto al tema del cuerpo es evidente que en la cultura occidental la visión de cuerpo que ha prevalecido es la visión heredada del cristianismo, desde sus categorías habituales se encuentra aún el dualismo de la filosofía griega, como se puede ver en la definición de hombre que da el Catecismo de la Iglesia Católica (1992): "El hombre es una criatura racional compuesta de cuerpo mortal y de alma inmortal". 
- En el siglo XX Michel Foucault a través de la investigación de archivos históricos plantea su idea de cómo el cuerpo fue involucrado con la violencia, la sexualidad, la locura, la prisión, el saber y poder. Libros como Vigilar y Castigar, la Historia de la Locura, la Microfísica del Poder, La verdad y las Formas Jurídicas, dan cuenta de estas investigaciones sobre el cuerpo, así como la construcción de una historia que descubre los ocultamientos y las relaciones de poder que se van evidenciando en el cuerpo, encontrándolo como "origen del origen" del poder y objeto de múltiples estrategias de disciplinamiento y control.

- Estas prácticas de control y disciplinamiento se originan desde el hogar, el colegio y el trabajo que son lugares donde se mantiene vigilado al individuo y se puede hacer un seguimiento o evaluación de todos sus movimientos y actitudes, lo cual denomina Foucault (2002) una "sociedad disciplinaria" que se hace evidente en la observación y control del cuerpo, convirtiéndolo en objeto de poder.

- De esta manera el cuerpo es el espacio de numerosas disciplinas impuestas por la sociedad con el fin de lograr unos determinados comportamientos y encasillándolo de acuerdo a los espacios en los que se desenvuelve, llámense estos: casa, fábrica, escuela, supermercados, centros comerciales, vías públicas, etc.; lo que ha dado como resultado un sujeto limitado en su movilidad, vigilado constantemente y coartado en su expresión corporal y desarrollo mental pues en cierto modo, la necesidad de sentir y pensar libremente va de la mano de satisfacer las necesidades que la sociedad y la cultura le imponen.

- En este aspecto el consumismo y la alta necesidad de tecnología de las sociedades modernas determinan ciertos comportamientos y conductas, además de hacer del sujeto un ser dependiente de nuevas y cada vez más sofisticadas máquinas que le permiten estar conectado con el mundo y en red con personas en lugares lejanos, pero a la vez se encuentra lejos de sí mismo.

- Se ha formado un ideal de sujeto que se mantiene atado a normas de conducta, pero si manifiesta sus ideales será etiquetado y enajenado de sus derechos, será cercado o encerrado en una prisión material o simbólica, es decir puede ir a una cárcel o a un hospital psiquiátrico, o simplemente será aislado y censurado por una sociedad que constantemente lo está observando. 
- La educación, la religión y la cultura han sido elementos determinantes en el dominio que la sociedad ejerce sobre los individuos, convirtiéndolos en sujetos sometidos a la ley que puede entrar en cualquier aspecto de la vida del individuo, sometidos a la educación que le determina las formas de comportamiento y desde el colegio da las pautas y las normas para vivir en sociedad, sometidos a la religión que desde la creencia de occidente se basa en el dominio del cuerpo y de todas las formas de expresión de la sexualidad, que solamente quedará confinada al matrimonio como institución encargada de velar por la familia, las buenas costumbres y la vivencia de valores cristianos al interior de la sociedad.

- El cuerpo ha sido el espacio donde convergen la religión, las costumbres, la cultura, la educación; también demuestra Michel Foucault que el cuerpo es elemento de discurso ya que se convierte en el espacio donde se elaboran discursos sobre las enfermedades que aquejan al hombre. De esta manera el cuerpo no es más que un territorio de indagación sobre síntomas y variantes que posibilitan o no el contagio de la enfermedad o la cura de ella.

- Este cuerpo en la persecución que históricamente se ha dado a la mujer sobre todo cuando se le ha relacionado con la hechicería se puede entender desde la biopolítica de Foucault como la visión de un cuerpo viviente convertido en una estrategia política y teniendo en cuenta el contexto también religioso, al buscar a través de "cuerpos dóciles", torturados a través del interrogatorio y la tortura para mantener una disciplina y un orden muy convenientes tanto para el poder civil como para el poder eclesiástico.

- En las reivindicaciones legales de los segregados se encuentra la dicotomía entre una legislación general que cobije y ampare los derechos de toda la población y una legislación que ampare específicamente a los grupos minoritarios. Según la Constitución Política Colombiana el Estado debe ser garante de la igualdad de derechos para toda la población según los Artículos 5 y 13, en este último se hace referencia a diversos grupos culturales presentes en el territorio colombiano, con lo cual se puede concluir que la Constitución de 1991 reconoce los derechos colectivos por encima de los derechos individuales, a la vez que reconoce los derechos culturales de las comunidades que se habían mantenido a la sombra de los derechos individuales, más sin 
embargo este reconocimiento también supone la vivencia de estos en la acción social, las prácticas culturales y las vivencias del día a día de estos grupos sociales y étnicos.

- En la vivencia diaria de los derechos promulgados por la Constitución es donde se encuentra la gran dificultad para los grupos de personas LGBTI, ya que es en la realidad y vida diaria de estas personas donde estos derechos no encuentran consistencia, como lo denuncia Colombia Diversa (2011), haciendo énfasis especialmente en tres ejes: "violencia por prejuicio, abuso policial, derechos de las parejas del mismo sexo, situación carcelaria y desplazamiento forzado"(p.7), adicionalmente se pueden encontrar situaciones evidentes de discriminación hacia personas LGBTI en los sitios de trabajo, las escuelas, los lugares de vivienda y los sitios públicos.

- Es importante resaltar que aunque en el plan de desarrollo nacional no hay visibilización especifica de personas LGBTI, a nivel Bogotá desde el año 2009 con el acuerdo 371 del Concejo de Bogotá, se ha reconocido una política pública concreta para Garantía plena de derechos de personas LGBTI e identidades de género en el Distrito Capital. En el año 2014 en Bogotá se adoptó el decreto 062 de 2014, en el cual además de dar garantía plena de derechos, se promulgan instancias de participación e instituciones que propenden por la garantía plena de derechos. Entre estas instituciones se encuentra la escuela como espacio de inclusión y diversidad, teniendo en cuenta que la escuela debe ser el espacio donde se formen ciudadanos que transformen la sociedad y la liberen de falsos imaginarios y prejuicios hacia las personas con una opción sexual distinta a la establecida desde la religión y la tradición.

- Por último es importante resaltar que es necesario construir una propuesta pedagógica de educación sexual, basada en la tolerancia y el respeto, una propuesta pedagógica que lleve a los individuos a ver al otro como complemento, y que desde el respeto a la sexualidad se pueda llegar a respetar todos los aspectos del ser humano. Para construir tal propuesta pedagógica propongo partir del proyecto de la Erótica de la Alteridad de Enrique Dussel (2007), desde la visión de la sexualidad como: "un momento constitutivo de la perfección ética y su ejercicio en la justicia es bondad liberadora servicial. El Otro, la mujer para el varón, el varón para la mujer, el hijo para la pareja" (p.113), de tal manera que desde la escuela y la familia como instituciones 
determinantes en el sistema de influencias educativas en una sociedad determinada y teniendo en cuenta que la primera desempeña un papel rector en la formación del hombre en correspondencia con el fin y los objetivos de la educación, respondiendo con los sistemas económicos y políticos, se debe constituir en el espacio de formación integral de la persona desde la ética, el respeto a la diferencia y la tolerancia. Es decir una educación que lleve a construir una cultura no excluyente, en la que tanto hombres como mujeres concedan un lugar prioritario a las manifestaciones de la sexualidad en todas sus formas, como primer eslabón en la construcción de una sociedad en la que se defienda el carácter único e insustituible de cada individuo humano, con independencia de su grado de desarrollo, origen, salud, forma de pensar, filiación política o características personales. Como un primer paso en la construcción de esta propuesta pedagógica se aplicó un instrumento de encuesta a jóvenes de grado $11^{\circ}$ (Anexo) que evidencia la forma como estos entienden aspectos teóricos tratados en la presente investigación, dando como resultado: - Los estudiantes en su gran mayoría confunden y entienden como sinónimos los términos sexualidad y género, y en gran medida identifican el primero con el acto sexual y el segundo con características físicas de las personas que los distinguen como hombres y mujeres, y muy pocos entienden el género como una construcción cultural de la sexualidad de la persona.

- En cuanto a las preguntas sobre la homosexualidad la mayoría de estudiantes se muestran respetuosos en sus respuestas hacia esta opción sexual, sin embargo un buen número de estudiantes expresan sus reservas en cuanto esta situación se presente en alguien cercano a ellos y también aclaran que en lo posible la persona homosexual no se meta en su vida privada.

- En esta misma línea más del 50\% de la población encuestada se muestra en desacuerdo con la adopción por parejas homosexuales, pero en cambio entre las razones que identifican como motivos de discriminación de personas LGBTI se encuentran la ignorancia, el miedo de la sociedad a aceptar la diferencia y el machismo.

- Finalmente los estudiantes coincidieron que hay una doble moral en el tema de la sexualidad al interior de la sociedad pues es un tema del que poco se habla con los padres, aunque hay muchas preguntas sobre este. 


\begin{abstract}
ANEXO
Para complementar y verificar las cuestiones tratadas en la presente investigación se aplicó el siguiente instrumento a estudiantes de grado $11^{\circ}$ de cuatro colegios de Bogotá, de igual número de localidades. En tres colegios la encuesta se hizo de forma documental y testimonial en uno de ellos.

Edad:

Sexo: Masculino $\square$ Femenino $\square$

Colegio:
\end{abstract}

Responde las siguientes preguntas de acuerdo a tus sentires y conocimientos:

1. ¿Para ti qué es sexualidad?

2. ¿Para ti qué es género?

3. ¿Qué opinas sobre la homosexualidad?

4. ¿Qué dice la religión sobre la sexualidad?

5. ¿Está la sexualidad ligada a la reproducción? ¿Por qué?

6. ¿Has hablado con tus padres sobre sexualidad? ¿Qué actitud han tomado ellos?

7. ¿Conoces qué son derechos sexuales y reproductivos?

8. ¿Conoces qué es la sigla LGBTI?

9. ¿Qué opinas sobre la virginidad?

10. ¿Quién debe llegar virgen al matrimonio: el hombre o la mujer?

11. ¿Quién debe llevar las riendas en una relación de pareja: el hombre o la mujer?

12. ¿Por qué los hombres son infieles?

13. ¿Por qué las mujeres son infieles?

14. ¿El amor es igual al sexo?

15. ¿Quién debe decidir sobre el aborto: La mujer, el hombre o las leyes? ¿Por qué?

16. ¿Quién debe llevar las riendas del hogar y de los hijos: el hombre o la mujer?

17. ¿Deben tener derecho a la adopción las parejas homosexuales?

18. Si un compañero (a) de tu curso se reconoce abiertamente como homosexual, ¿Cuál sería tu comportamiento con él o ella?

19. ¿Por qué las personas LGBTI son discriminadas en la sociedad? 
20. ¿Crees que en la sociedad se maneja una doble moral en cuanto al tema de la sexualidad? ¿Por qué?

Las condiciones generales de aplicación del instrumento fueron los siguientes: En el Colegio General Gustavo Rojas Pinilla (localidad 8): Se aplicaron 22 encuestas, respondieron 10 mujeres cuyas edades oscilan entre los 16 y 17 años y 12 hombres con edades entre 15 y 20 años. En el Colegio Técnico Benjamín Herrera IED (localidad 16): Se aplicaron 10 encuestas, respondieron 5 mujeres cuyas edades oscilan entre los 15 y 16 años y 5 hombres, cuyas edades oscilan entre 16 a 18 años. En el colegio Instituto Técnico Internacional IED (localidad 9): Se aplicaron diez encuestas, de las cuales respondieron ocho mujeres cuyas edades oscilan entre los 16 y 17 años y dos hombres con edades que oscilan entre los 16 y 18 años. En el Colegio Estrella del Sur IED (localidad 19): En esta institución las encuestas se hicieron de forma testimonial y participaron de ellas cinco niñas en edades entre los 16 y 18 años y también respondió la encuesta un joven de 15 años.

Las generalidades a destacar en estas encuestas son:

Con respecto a la pregunta uno: Se puede identificar como constante que los estudiantes asocian la sexualidad con las relaciones íntimas de la pareja, e incluso asocian la sexualidad como una forma de demostrar amor, mientras que menos del 10\% de los estudiantes identifican la sexualidad como el ser hombre o mujer o con la forma de relacionarse con personas de otro sexo. Es de resaltar que en su gran mayoría las mujeres ven la sexualidad como relaciones íntimas. En la encuesta testimonial se encontraron respuestas como: "Entiendo que la sexualidad está conformada por las características físicas y psicológicas de cada persona y también los momentos de placer sexual que vivimos a lo largo de nuestra vida”.

En la pregunta dos se encuentra que el $70 \%$ entre mujeres y hombres de todos los colegios en los que se aplicó el instrumento; entienden el género como las diferencias en su mayoría físicas que distinguen hombres y mujeres, y solamente un estudiante asocia el término con la identificación como hombre o mujer y con la forma de actuar y otro con la opción sexual. En la encuesta testimonial se encontraron respuestas como: “Género es una serie de características o cualidades las cuales diferencian a un ser humano". 
En la pregunta tres la opinión frente a la homosexualidad está claramente dividida sobre todo en los hombres, quienes ven la homosexualidad como una opción personal, pero aunque la respetan aclaran que no la comparten e incluso un estudiante la vio como "antinatural". En cuanto a las mujeres se evidencia una clara actitud de apertura hacia este tema, pues expresan que es una opción desde la libertad de cada persona y por tanto se debe respetar; sin embargo una estudiante describió la homosexualidad como algo que está de moda entre los jóvenes. En las encuestas testimoniales se encontraron respuestas como esta; "es algo distinto que nace en las personas, en la cual se basa de una atracción, gusto, sentimiento, entre otras, en dos personas del mismo sexo. Pienso que eso se da no por que las personas decidan ser así sino porque antes de nacer sus hormonas se desarrollan distinto". Por lo que se puede encontrar que este es un tema que despierta bastante controversia entre los jóvenes, a la vez que curiosidad.

En la pregunta cuatro se encuentra que cerca del 50\% de estudiantes tanto hombres como mujeres encuentran que la sexualidad vista desde la religión solamente se acepta en el marco del matrimonio, con una pareja estable en la que hombre y mujer se deben responsabilidad, respeto y amor. Mientras que cerca del 25\% considera los temas sexuales como prohibidos por la religión, e incluso consideran que son vistos como pecado y lo que busca la religión es controlar todas las conductas sexuales del ser humano. Una estudiante respondió que la religión tiene una visión escatológica de la sexualidad, pero no dio explicación al respecto. Se encontró que varios estudiantes no conocen que dice la religión sobre la sexualidad. En las encuestas testimoniales se encontraron respuestas como: "La posición de la iglesia con relación a la sexualidad es algo creado por Dios la procreación de la especie y que el uso de este deber ser dentro de un marco moral y de respeto mutuo".

En la pregunta cinco se encontró que para cerca del $86 \%$ de las mujeres la sexualidad está totalmente ligada a la reproducción, pues siempre que se tienen relaciones íntimas hay posibilidad de embarazo, mientras que el $70 \%$ de los hombres encontraron relación directa entre sexualidad y reproducción y el porcentaje restante respondió que siempre hay la posibilidad y opción de cuidarse y evitar embarazos. Es importante resaltar que en las respuestas de las mujeres se encuentra latente la preocupación por el embarazo no deseado. En cuanto a las 
encuestas testimoniales se encuentran respuestas como esta: "Si ya que sin sexualidad no podemos reproducirnos y crear nuevas generaciones".

En la pregunta seis las respuestas también se encuentran divididas pues en los hombres un poco más del $60 \%$ trata temas de sexualidad con sus padres, quienes se preocupan por darles consejos acerca de protegerse y evitar embarazos no deseados, mientras que el resto de estudiantes dice que no trata temas de sexualidad con sus padres. En las mujeres se encuentra que cerca del $58 \%$ de ellas conversa con sus padres sobre sexualidad y el resto argumenta que no se tocan esos temas con la familia y que además les da pena preguntar o tratar estos temas con sus padres. En cuanto a las encuestas testimoniales se encontraron respuestas como: "Sí, es algo normal, pero se sorprenden cuando uno pregunta acerca de este tema”.

En la pregunta siete se hace evidente sobre todo en el colegio de la localidad de Kennedy, que los estudiantes no conocen que son derechos sexuales y reproductivos, en los demás colegios las opiniones se encuentran divididas, aunque sobresale que las mujeres dicen conocer más que los hombres sobre estos derechos. En cuanto a las encuestas testimoniales hay respuestas como la siguiente: "Conozco muy poco sobre los derechos, pero por lo que tengo entendido son los más comunes en los seres humanos". Por lo tanto se hace evidente que aunque los jóvenes están bombardeados de información sobre este tema, ellos se encuentran confundidos sobre este aspecto o algunos casos desconocen totalmente cuáles son sus derechos en cuanto a la vivencia de su sexualidad.

En cuanto a la pregunta ocho el $85 \%$ de los hombres conoce que las palabras de la sigla LGBTI, el $90 \%$ de todas las mujeres encuestadas también lo saben, pero tanto en hombres como en mujeres no tienen seguridad en lo que quiere decir la última letra de la sigla. En cuanto a las encuestas testimoniales, hay respuesta como la siguiente: "Si esta sigla define lesbianas, gais, bisexuales, transexuales, e intersexuales”, -"Significa (Lesbianas, gais, bisexuales y transexuales) La sigla "I" en verdad no sé qué significa".

En la pregunta nueve se encuentra que la opinión entre hombres y mujeres con respecto al tema de la virginidad es bien distinto, pues para los hombres la virginidad es una cuestión 
relacionada con el iniciar la vida sexual, es una opción libre de entregarse a quien decidan hacerlo, un estudiante consideró que es una cuestión mental y para otro es algo meramente cultural. Mientras que para las mujeres en un 75\% están de acuerdo en responder que la virginidad es algo valioso para la mujer, que es un tesoro, que se debe cuidar y que se debe guardar hasta el matrimonio, mientras que solo una estudiante respondió que la virginidad no existe y es un mito sexual. Esto se evidencia en algunas respuestas de las encuestas testimoniales: "Me parece que es una forma de mantenerse "puro" pero pues existe la libertad individual de decidir por sí mismo al ser vírgenes o no".

Con la pregunta diez los resultados fueron bastante similares en todos los colegios, coincidiendo los hombres en un $70 \%$ que tanto hombre y mujer deben llegar vírgenes al matrimonio, mientras que esta respuesta en las mujeres fue del $46 \%$, por otra parte hay quienes consideran que ninguno de los dos debe llegar virgen al matrimonio, pues es decisión personal iniciar la vida sexual, el porcentaje de hombres es de $27 \%$, mientras para las mujeres es de $50 \%$, dando como resultado que estas respuestas son las más homogéneas tanto en hombres como en mujeres, mientras que solamente un estudiante consideró que quien debe llegar virgen al matrimonio es la mujer. En cuanto a las encuestas testimoniales, se encuentran respuestas como: "En la época de antes era una mujer pero pienso que debería llegar los dos.

En la pregunta once, las respuestas son bastantes similares tanto en hombres como en mujeres de todos los colegios encuestados, pues cerca del $90 \%$ de hombres y mujeres estuvieron de acuerdo en que la responsabilidad de la relación la deben tener tanto hombre como mujer, pues es algo que se construye en igualdad. Solamente un hombre y una mujer respondieron que el hombre debe liderar la relación. Con respecto a las encuestas testimoniales se encuentran respuestas como: "Las riendas las deben de llevar los dos ya que están construyendo una relación".

En cuanto a la pregunta doce las respuestas de los hombres se encaminan a indicar que la causa de la infidelidad masculina es su naturaleza misma, la falta de libertad en la relación, insatisfacción con la pareja y falta de amor, mientras que las mujeres identificaron las siguientes causas: insatisfacción con la pareja, autoestima, mantener el ego, falta de respeto y valoración de 
su pareja, y en menor porcentaje consideran que por egoísmo y por inseguridad personal. En cuanto a las encuestas testimoniales se encuentran este tipo de respuestas: "los hombres son infieles porque creo que les hace falta algo en la relación y además creo que ellos creen que siendo infieles la sociedad los aceptara mejor".

En la pregunta trece sobre la infidelidad femenina, los hombres encuentran entre las principales causas: perdida de interés por la pareja, falta de confianza y valorar, búsqueda de libertad, un pequeño porcentaje dijo que por venganza por los malos tratos que reciben de sus parejas, o porque no se sienten valoradas, o simplemente por falta de amor. Para las mujeres los motivos de infidelidad femenina se pueden ver como principal causa: venganza con los hombres, inconformidad con la pareja, y una estudiante respondió que por naturaleza femenina. En las encuestas testimoniales se encuentran respuestas como: "las mujeres son infieles porque en alguna ocasión las lastimaron y quieren tomar como venganza es decir que puede que con su pareja no se sienta bien".

En la pregunta catorce tanto hombres como mujeres estuvieron en un porcentaje de casi $80 \%$ de acuerdo que el sexo y el amor son totalmente distintos y argumentaron que el amor es más completo pues implica sentimientos hacia la otra persona. Para un joven y dos mujeres el amor y el sexo son iguales, porque el sexo es expresión del amor. Según las encuestas testimoniales, se dan respuestas como: "No, ya que el amor es un gran sentimiento y además se hace con las personas que se quiere y el sexo es algo pasajero".

En la pregunta quince, las opiniones son bastante diferentes entre hombres y mujeres, pues para cerca del $50 \%$ de los hombres quienes deben decidir sobre el aborto son los miembros de la pareja, mientras que para el mismo porcentaje de mujeres quien debe decidir sobre el aborto es la mujer, pues es dueña de su cuerpo y de lo que se haga con él. Es de resaltar que aunque hombres y mujeres coinciden en decir que la vida es sagrada y que no se debe atentar contra ella, esta respuesta es mucho más evidente en los hombres, con un porcentaje de cerca del $30 \%$ y en las mujeres es mucho menor con un porcentaje de $15 \%$. Con lo cual se puede concluir que la decisión del aborto recae indirectamente sobre la mujer y finalmente es ella quien debe afrontar las consecuencias de la decisión. En cuanto a las encuestas testimoniales, se dan respuestas 
como: "eso es un tema delicado ya que se está tratando de la vida de un ser humano inocente, yo pensaría que ninguno tiene el derecho a quitarle la vida a esta personita...".

En la pregunta dieciséis la totalidad de los hombres consideraron que la responsabilidad del hogar y de la educación de los hijos debe ser asumida por los dos miembros de la pareja, pues es algo que se construye entre los dos. Mientras que en las mujeres un bajo porcentaje, cerca del $20 \%$ piensa que la responsabilidad del hogar corresponde al hombre, pues es quien se encarga de trabajar para sostener el hogar. En las encuestas testimoniales se encuentran respuestas como: "En si es común en el hombre, pero creo que el hombre como la mujer tienen el derecho de tener su espacio y autoridad en el hogar".

En la pregunta diecisiete se ve claramente que las opiniones tanto en hombres como en mujeres están divididas, pues cerca del 50\% de los hombres está de acuerdo con la adopción por parejas de homosexuales, mientras que en un colegio la totalidad de los jóvenes se manifestaba en contra de esta. En las mujeres la opinión se dio de una manera más conservadora, pues cerca del $60 \%$ de ellas responde que no debe haber derecho a la adopción para las parejas homosexuales, pues consideran que la familia se forma por hombre y mujer, mientras que el porcentaje restante responde que si deben tener derecho a adoptar, pero teniendo en cuenta que los niños deben tener derecho al amor y a un hogar. En cuanto a las encuestas testimoniales, se encuentran respuestas como: "Pienso que no, ya que no es correcto un niño (a) tener un ejemplo de vida totalmente distinta a la que deberían tener o sentir amor de padre y madre".

En la pregunta dieciocho se encuentra que los jóvenes tanto hombres y mujeres se muestran respetuosos ante el reconocimiento homosexual de alguien cercano de su curso, sin embargo en su mayoría los hombres después de decir que aceptan la situación, ponen una condición con tal aceptación; algunos dicen que lo mejor sería ser indiferente y alejar un poco esta persona, sobre todo si es de su mismo sexo, también dicen que respetarían pero que no se meta en su vida. Las mujeres ponen menos condicionantes y en sus respuestas evidencian más tolerancia ante esta situación. En cuanto a las encuestas testimoniales, se pueden encontrar respuestas como: "Pienso que la misma ya que se da sin querer, no es motivo de juzgar o criticar todos tienen el derecho a la igualdad". 
En la pregunta diecinueve los motivos que se reconocen como causantes de la discriminación a personas LGBTI, son los siguientes: en mayor proporción hombres y mujeres identificaron la religión, las creencias y las tradiciones como causantes de esta problemática. Un buen grupo de hombres identificó el machismo como factor de discriminación. También se estableció que la ignorancia y el miedo a las expresiones diferentes son factores de discriminación e incluso se llegó a concluir que a muchos se les discrimina sin siquiera conocerlos. Un estudiante respondió que consideraba que actualmente no se discrimina a las personas LGBTI, pues son mucho más visibles en la sociedad. En cuanto a las encuestas testimoniales se pueden encontrar respuestas como: "Para la sociedad es impresionante ver personas de diferente sexualidad ya que lo ven como una falta de respeto ante la sociedad, piensan que les falta integridad y conocimientos por eso los discrimina la sociedad".

Con respecto a la pregunta veinte, alrededor del $75 \%$ de los hombres respondieron que hay doble moral en la sociedad, pues se condenan situaciones que se practican ocultamente, mientras el porcentaje restante respondió no saber sobre el tema o no respondió la pregunta. Para las mujeres cerca del $80 \%$ considera que la sociedad maneja doble moral en cuanto a los temas sexuales, pues se reconoce como un tema importante, pero no se maneja directamente cuando se debe tratar. El porcentaje restante de las mujeres respondió que no sabe sobre el tema. En cuanto a las encuestas testimoniales, se encuentran respuestas como: "Si ya que la sociedad frente a un pueblo o comunidad hablan de que la sexualidad debe ser algo normal pero al aplicar este tema en familia creen que están fomentando a tener relaciones sexuales”. 


\section{REFERENCIAS BIBLIOGRAFICAS}

- Adrados, F. (1975). La democracia ateniense. Madrid: Alianza.

- Agamben, G. (2006). Homo Sacer, El poder soberano y la nuda vida. Valencia: PRE-TEXTOS.

- Ariès, P. \& Duby, G. (2001). Historia de la vida privada, V.4: De la revolución francesa a la primera guerra mundial. Madrid: Taurus.

- Ariès, P. (1988). El niño y la vida familiar en el antiguo Régimen. Madrid: Taurus.

- Bogotá. Decreto 062 de 2014, de Febrero 07 de 2014, por el cual se adopta la Política Pública para la garantía plena de los derechos de las personas lesbianas, gay, bisexuales, transgeneristas e intersexuales- LGBTI - y sobre identidades de género y orientaciones sexuales en el Distrito Capital, y se dictan otras disposiciones. En: http://www.alcaldiabogota.gov.co. Consultado: 29mayo-2014.

- Borja, J. \& Rodríguez, P. (2011). Historia de la vida privada en Colombia, Tomo I: las fronteras difusas. Bogotá: Taurus.

- Caro Baroja, J. (1997). Las brujas y su mundo. Madrid: Alianza Editorial.

- Castilla, C. (2009). Eso no se hace, eso no se toca, de eso no se habla. La desigualdad de género en las religiones. Gaceta de Antropología. No. 25. Artículo 40. Recuperado de: http://hdl.handle.net/10481/6911

- Chomsky, N. Foucault, M. (2006). La naturaleza humana: justicia versus poder. Un debate. Katz Editores. Recuperado de: http://new.pensamientopenal.com.ar/.

- Cieza de León, P. (1944). Del Señorío de los incas. Buenos Aires: Biblioteca Hispano-Ultramarina.

- Colombia (2013), constitución Política, Bogotá: Grupo editorial Thorre Fuerte.

- De la Pedraja, R. (1984) La mujer criolla y mestiza en la sociedad colonial, 1700-1830. Revista Desarrollo y Sociedad, (No 13).

- Duby, G. (1998). Mujeres del siglo XII. Santiago de Chile: Editorial Andrés Bello.

- Dussel, E. (2007). Para una erótica latinoamericana. Caracas: Fundación editorial el perro y la rana.

- Espeja, Jesús. (2002). Para comprender los sacramentos. Navarra: Verbo Divino.

- Fernández de Oviedo, G. (1950). Sumario de la natural historia de las indias. México: Fondo de cultura económica.

- Flores Galindo, A. (1984). Aristocracia y plebe. Lima 1760-1830. Lima: Mosca Azul.

- Foucault, M. (1979). La arqueología del Saber. Bogotá: Siglo veintiuno de Colombia, Ltda.

- Foucault, M. (1985). Las palabras y las cosas. Barcelona: Planeta Agostini. 
- Foucault, M. (1992). Microfísica del poder. Madrid: La Piqueta.

- Foucault, M. (1996). La verdad y las formas jurídicas. Barcelona: Ed. Gedisa.

- Foucault, M. (1998). Historia de la locura en la época clásica I. Colombia: Fondo de Cultura Económica.

- Foucault, M. (1998). Historia de la locura en la época clásica III. Colombia: Fondo de Cultura Económica.

- Foucault, M. (2002). Vigilar y castigar. Buenos Aires: Siglo Veintiuno Editores.

- Foucault, M. (2004). El nacimiento de la clínica. Argentina: Siglo Veintiuno Editores.

- Foucault, M. (2006). Sobre la Ilustración. Madrid: Tecnos.

- Foucault, M. (2007). Historia de la sexualidad. Vol I: La voluntad del saber; Vol. II: El uso de los placeres; Vol. III: La inquietud de sí. Buenos Aires: Siglo Veintiuno.

- Foucault, M. (2007). Los Anormales. Curso en el College de France (1974-1975). Buenos Aires: Fondo de Cultura Económica.

- Foucault, M. (2007). El nacimiento de la Biopolítica. Buenos Aires: Fondo de Cultura Económica.

- Freud, S. (1981). Obras completas - Tomo II. Tres ensayos para una teoría sexual. Madrid: Editorial biblioteca nueva.

- Freud, S. (1981). Obras completas - Tomo III. El malestar en la cultura. Madrid: Editorial biblioteca nueva.

- Gamboa, J. (2003). El precio de un marido. Bogotá: Instituto colombiano de antropología e historia.

- Ghul E. \& Koner W. (2002). Los griegos, su vida y costumbres. España: Edimat Libros S.A.

- Habermas, J. (1999). La inclusión del otro Estudios de teoría política. Barcelona: Ediciones Paidos.

- Iglesia Católica. Catecismo de la iglesia católica. Constitución Apostólica Fidei Depositum. Vaticano: Librería Editrice Vaticana, 1992

- Kymlicka, W. (1966). Ciudadanía Multicultural. Barcelona: Paidós Estado y Sociedad.

- Lavrin, A. (1985). Las mujeres latinoamericanas. Perspectivas históricas. México: Fondo de cultura económica.

- Lavrin, A. (1991). Sexualidad y matrimonio en la América hispánica siglos XVI-XVIII. México: Consejo Nacional para la Cultura y las Artes.

- López de Gomara, F. (2003). Historia general de las Indias. Argentina: Biblioteca Virtual Universal. Recuperado de: http://www.biblioteca.org.ar/libros 
- López, C. (Febrero 2004). Epicuro: Textos. Biblioteca Virtual Antorcha. http://www.antorcha.net/biblioteca_virtual/filosofia/epicuro/epicuro.html\#2. Consultado: 17-oct13

- Marcuse, H. (1993). El hombre unidimensional. Barcelona: Editorial Planeta-De Agostini, S.A.

- Marcuse, H. (1983). Eros y civilización. Madrid: Sarpe S.A.

- Platón. (2011). Fedón o Acerca del alma. Recuperado de www.philosophia.cl/biblioteca/platon/Fed\%F3n.pdf. Consultado: 17-oct-13.

- Rev. Filosofía Univ. Costa Rica, XLIV (111-112), 153-163, Enero-Agosto 2006. Consultado: 25-05-12

- Reyes, C. (2005). Culturas precolombinas. Unitec Auckland. Consejería de educación en Australia y Nueva Zelanda. Consultado: 25-abril-2013.

- Rodríguez, R. (1984). Divorcio y familia tradicional. Buenos Aires: Centro Editor de América Latina.

- San Agustín, comentario al génesis en réplica a los maniqueos. Recuperado de: www.augustinus.it/. Consultado: 11-abril-2013.

- San Agustín, Contra Faustum. Recuperado de: www.augustinus.it/. Consultado: 11-abril-2013.

- San Agustín, La bondad del matrimonio. Recuperado de: www.augustinus.it/. Consultado: 11-abril2013.

- San Agustín, La continencia. Recuperado de: www.augustinus.it/. Consultado: 11-abril-2013.

- Sánchez, M. (2011). Todos los deberes, pocos los derechos Situación de derechos humanos de lesbianas, gay, bisexuales y transgeneristas en Colombia 2008-2009. Bogotá: Colombia diversa.

- Schopenhauer, A. (2005). El mundo como voluntad y representación. Madrid: Editorial Trotta S.A.

- Sejourné, L. (1971). Antiguas culturas precolombinas. Madrid: Siglo XXI.

- Seneca, L. (1971). Consolación a Helvia, Cartas a Lucilio sobre los beneficios. España: Salvat Editores S.A.

- Seneca, L. cartas a Lucilio. España. Editorial Juventud. http://www.editorialjuventud.es/1933.html.

- Séneca, L. Epístolas de Seneca a su buen amigo Lucilio. Biblioteca Virtual Miguel de Cervantes. España. www.cervantesvirtual.com. Consultado: 7-nov-13

- Soto, R. (1992). Negras Esclavas. Las otras mujeres de la Colonia. Revista proposiciones No. 21, p.2131. Recuperado de: http://www.sitiosur.cl/r.php?id=536

- Troconis de Veracochea, E. (1984). Aspectos generales de la esclavitud en Venezuela. Revista Tierra Firme, (No. 8). Recuperado de: http://www2.scielo.org.ve 
- Uribe de H, M. (1999). Comunidades, ciudadanos y derechos. En Marín, Diego. Multiculturalismo los derechos de las minorías culturales (pg.143-157). Instituto de Filosofía de la Universidad de Antioquia.

- Velandia, M. (2007, julio). Manuel Antonio Velandia Mora, Autografía y Artículos. Recuperado de: http://manuelvelandiaautobiografiayarticulos.blogspot.com/Consultado: 25-05-12.

- Westheimer, R., Jonathan, M. (1997). Sexo divino, Sexualidad en el Judaísmo. Colombia: L.B. Publishing Co.

- www.educacionbogota.edu.co/Educación incluyente. Consultado: 29-mayo-14. 